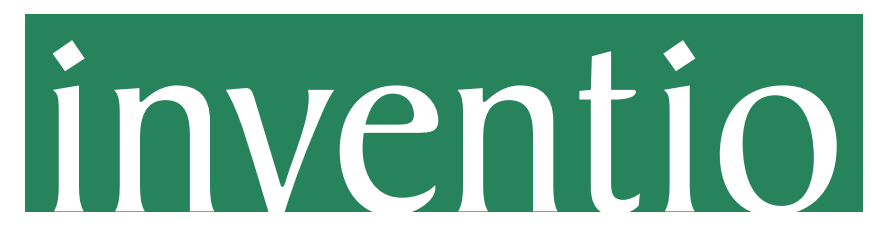

La génesis de la cultura universitaria en Morelos

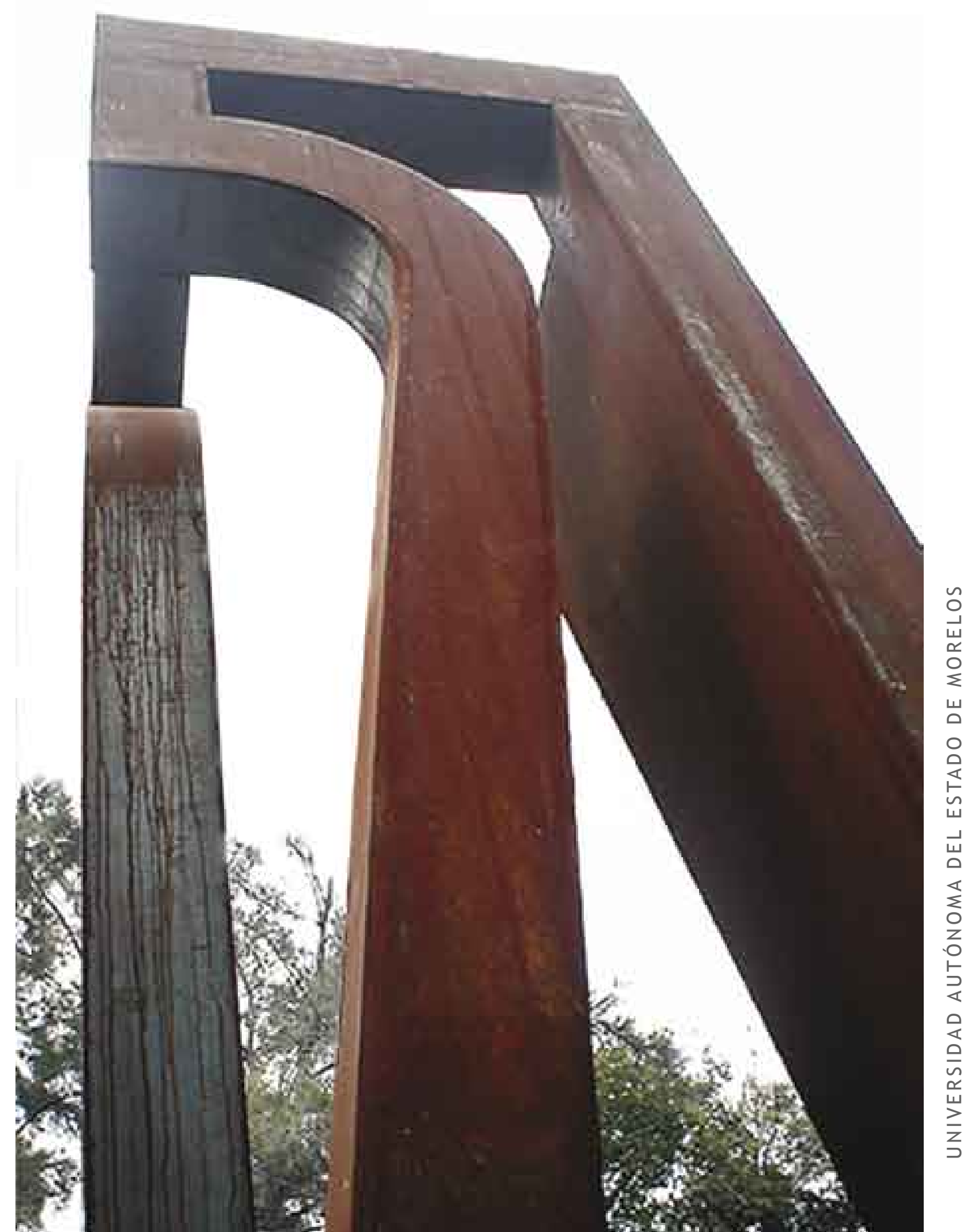


La inventio, según Aristóteles, es la primera parte de la retórica y consiste en la exploración de los propios hechos del discurso y de qué manera pueden ser utilizados como fuente de convicción y de persuasión. Desde un punto de vista empírico, es la búsqueda de ideas acerca de un tema determinado.

$\mathrm{E}$ I hecho de que la Universidad Autónoma del Estado de Morelos haya cumplido treinta años de realizar investigación de manera ininterrumpida, ha representado un importante esfuerzo que de manera sostenida la institución ha ido incrementado gradualmente.

En sus orígenes, la investigación respondía a las inquietudes de profesores y alumnos de las entonces escuelas de Ciencias Biológicas y de Ciencia Químicas, pero después de muchos años de trabajo diario se ha logrado institucionalizar la investigación, tanto en las áreas científicas y como en las humanísticas, a tal punto de que en la actualidad la Universidad Autónoma del Estado de Morelos cuenta con poco más de 400 profesores-investigadores de tiempo completo, que cultivan diversas líneas de generación y aplicación del conocimiento, muchas de las cuales han tenido impacto relevante a nivel nacional e internacional.

Este trabajo diario y profesional de años ha conducido a que la UAEM sea destacada entre las Instituciones de Educación Superior del país por su perfil de investigación y además ha contribuido a la modificación de los procesos educativos en la mayoría de sus facultades e institutos, donde los alumnos aprenden de primera mano a través de nuevas modalidades de enseñanza de quienes están a la vanguardia del conocimiento.

Si bien para la consolidación de la mayoría de las líneas de investigación se requiere de la publicación de los resultados en revistas especializadas de cada disciplina, buscamos también mejorar los canales de comunicación que conduzcan a propuestas multidisciplinarias para divulgar con mayor amplitud los resultados de estas investigaciones. Consideramos fundamental contar con un medio de transmisión de la información para un público general, como es la revista Inventio, que en esta ocasión publica su tercer número y que sabemos es un aporte más para la divulgación y el fortalecimiento de los estudios que se realizan en la Universidad.

POR UNA HUMANIDAD CULTA

Topiltzin Contreras

Secretario Académico 
La génesis de la cultura universitaria en Morelos

Revista Inventio

Año 2 • número 3 • marzo 2006

\section{Rector}

René Santoveña

\section{Secretario Académico}

Topiltzin Contreras

\section{Directora}

Lydia Elizalde

\section{Editor}

Gustavo Martínez

\section{Consejo editorial}

Eduardo Aranda (Dirección de Investigación y Posgrado)

Carlos Acosta (Ciencias Agropecuarias)

Verónica Narváez (Ciencias Exactas e Ingenierías)

Fernando Bilbao (Ciencias de la Salud)

Gabriel Iturriaga (Ciencias Naturales)

Juan de Dios González (Ciencias Sociales y Administrativas)

Ivonne Pallares (Humanidades)

\section{Diseño gráfico}

Comité Editorial / Carolina Valdez

\section{Redacción}

Daniel Zetina

Inventio es una publicación semestral editada por el Comité Editorial de la Universidad Autónoma del Estado de Morelos. Certificado de reserva de derechos al uso exclusivo (en trámite) expedido por el Instituto Nacional del Derecho de Autor. Certificado de licitud de título (en trámite), expedido por la Comisión Calificadora de Publicaciones y Revistas Ilustradas. Distribución en Morelos: Librería Universitaria, la AEUyAM y la AEUE. Impresión: Dicograf S.A. de C.V., Poder Legislativo 304, Cuernavaca, Morelos. Precio $\$ 50.00$. Suscripciones por un año: República Mexicana $\$ 100.00$, EUA y Canadá $\$ 10.00$ US, Sudamérica y Europa $\$ 15.00$ US, números atrasados $\$ 60.00$. Oficinas: Comité Editorial, Av. Universidad 1001, Edificio 19, Col. Chamilpa, Cuernavaca, Morelos, México. Tel. (01 777) 329 7005, ext. 3642. Inventio no devuelve originales ni expide cartas a sus colaboradores. Las bases pueden consultarse en www.uaem.mx; comite.editorial@uaem.mx. 
Carta editorial

Voces y trazos de Morelos

$5 \quad$ El sentido en los murales de la Catedral de Cuernavaca María del Carmen Turrent

11 Apropiación de recursos en comunidades rurales Elsa Guzmán

Pensamiento y lenguaje universitario

19 La investigación interdisciplinaria en diseño arquitectónico Andrea Martín

Juan de Dios González

25 La administración educativa de los menores infractores Ladislao Reyes

33 Cómo traer un congreso a casa Lauro Zavala

Narraciones de la ciencia

39 Reforestar o restaurar para la recuperación ambiental Óscar Dorado

Dulce María Arias

45 Astrobiología, una nueva disciplina científica Sandra I. Ramírez Horacio Terrazas

55 Insecticidas alternativos para el control de plagas en granos almacenados María Idalia Cuevas

Pasiones de la utopía

61 Adolfo Sánchez Vázquez, una veta para la educación valoral María Teresa Yurén

71 Crítica o creatividad Silvia Kiczkovsky
77 De la ironía y del juego Rocco Mangieri

Artificios

83 Elementos del patrimonio monumental francés en México

Françoise Dasques

88 La libertad de articulación Lydia Elizalde

89 Pawel Anaszkiewicz, obra escultórica

93 A ver

Juan Gelman

Cátedra Alfonso Reyes

95 La persona de Hernán Cortés José Luis Martínez

Significar con textos

103 El Colmillo Público Luis Tamayo

111 Manuscritos del Fondo Reservado de la Biblioteca Nacional

Silvia Salgado

116 Otros textos

118 Ediciones y coediciones

Las esculturas que ilustran este ejemplar pertenecen a la obra Pawel Anazkiewicz realizada de 1993 a 2004

El contenido de los artículos que presenta Inventio muestra la diversidad del pensamiento universitario y es responsabilidad de sus autores 


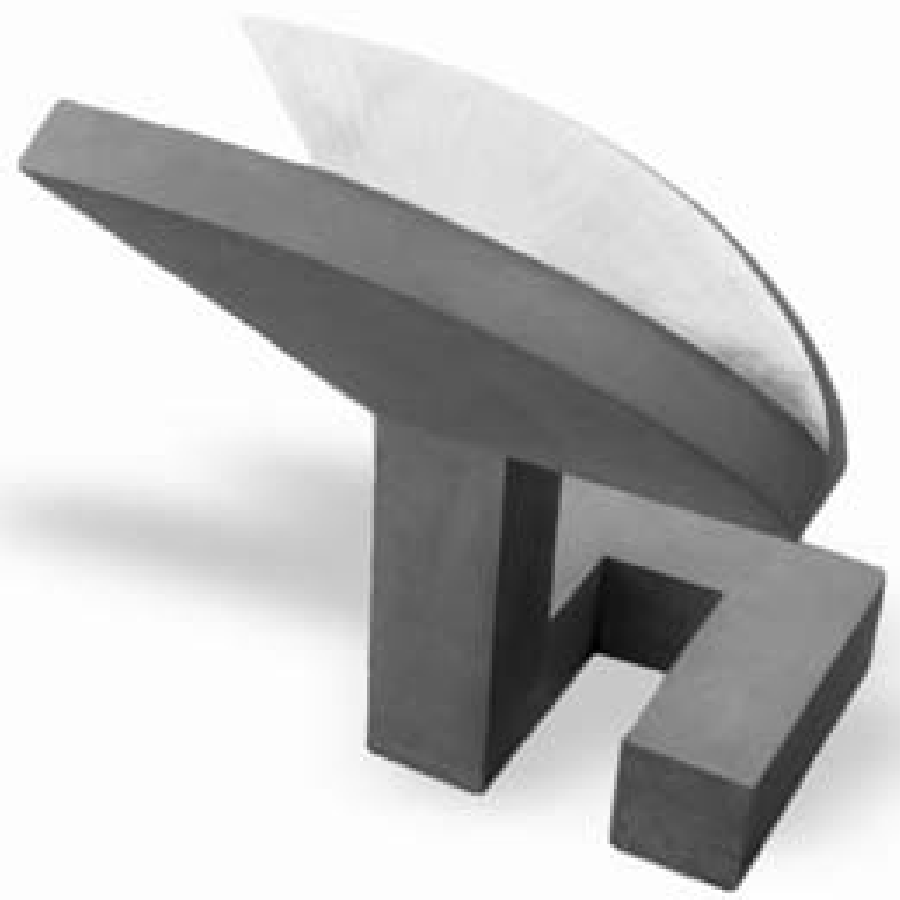

Nahual III, 1997 


\section{El sentido en los murales de la Catedral de Cuernavaca}

- María del Carmen Turrent

E I trabajo que leerán a continuación tiene como objeto de estudio los murales que recubren las paredes de la nave central de la Catedral de Cuernavaca, Morelos, los cuales ilustran el martirio de veinticuatro personajes, frailes franciscanos, jesuitas y seglares japoneses conversos a la religión católica, ocurrido en Nagasaki, Japón, en 1597. Entre los frailes franciscanos crucificados encontramos a San Felipe de Jesús, primer santo mexicano y de América. La manufactura de los murales ha sido fechada por el INAH como de principios o mediados del siglo XVII; su descubrimiento, durante la restauración de la iglesia, data de 1957.

La intención de este escrito es compartir con el lector algunos elementos que facilitaron la construcción de una gramática que me permitió leer el objeto estudio. Únicamente toco, sin ser exhaustiva, conceptos que pertenecen a la semiótica y a la teoría literaria, dejo para otra ocasión el manejo que se dio a la propuesta de Fernande SaintMartin ${ }^{1}$ en relación con el análisis coloremático de textos visuales. Para establecer la coherencia del texto visual, consideré tres tiempos históricos, en los cuales aparece el relato de los murales: el siglo $X V I$, el XVII y finalmente nuestros días. Éstos responden a los momentos en que se realizan los hechos, ${ }^{2}$ cuando fueron pintados los murales ${ }^{3}$ y cuando, posteriormente, se descubrieron. Los tiempos se convirtieron en horizontes, ${ }^{4}$ a partir de los cuales establecí un diálogo constante con el texto visual mediante los colores, las texturas y las formas relacionadas con la historia y con los personajes plásticos.

Puesto que esta historia visual se sustenta en textos escritos que pertenecen a géneros literarios retóricos bien definidos, partí de ellos para establecer los elementos necesarios. Consideré entonces como géneros literarios para el análisis de los murales: sermones, biografías, crónicas, poemas, leyendas, mitos, y como apoyo, por estar íntimamente relacionados con el tema y ayudar a la lectura, pinturas, grabados y música de las épocas.

${ }^{1}$ F. Saint-Martin. Semiotics of visual language. Indianapolis, Indiana University Press, 1990.

2 En L. Knauth. Confrontación transpacífica. El Japón y el Nuevo Mundo Hispánico 1542-1639. México, UNAM, 1972; F. Santiago Cruz. La Nao de China. México, Jus, 1962; J. Whitney Hall. El Imperio Japonés. México, Siglo XXI, 1992.

${ }^{3}$ En L. Islas García. Los murales de la Catedral de Cuernavaca Afronte de México y Oriente. México, La esfera, 1967; J. Miranda. Estudios novohispanos. México, UNAM, 1995; F. Morales. Franciscanos en América. México, Curia Provincial Franciscana, 1993.

${ }^{4}$ H.G. Gadamer. Verdad y Método I. Salamanca, Ediciones Sígueme, 1994.

- Profesora-Investigadora, Universidad Pedagógica Nacional, Unidad Morelos 
Greimas y Eco ${ }^{5}$ han establecido los caminos de la semiótica en el análisis de textos visuales. Estos autores fueron fundamentales al igual que SaintMartin, quien establece una metodología alrededor de la sintaxis visual con características que se adaptaron perfectamente a mis necesidades de análisis. Debe quedar muy claro que la forma de trabajo propuesta se adecua específicamente a textos visuales sustentados en narraciones, leyendas, sermones o epístolas, es decir, que tengan un sustrato escrito que permitan formar un corpus ${ }^{6}$ narrativo mediante el cual podamos reconstruir la historia.

El carácter del análisis se aleja entonces de los datos, dimensiones, descripciones rígidas sobre el objeto de estudio y se adentra en lo que se dice, habla o comenta acerca de él. Parte de la historiografía y las imaginerías de los pueblos va hacia aquello que la gente dice y a las maneras como la historia ha influido en el conocimiento popular y éste a su vez en ella, en la concepción estética y en las intenciones del mensaje, es decir, el descubrimiento de un sentido en el que confluyen factores semióticos, estéticos e históricos y literarios. De esta manera, aun cuando no se lo proponga, la literatura elabora y cuestiona la historia, podría decir, la otra historia en la que los horizontes, fundamentales en el estudio del texto, afloran significativamente y nos permiten atisbar en los sucesos.

Asimismo, fue importante salvar las dificultades metodológicas que proporcionara, desde nuestro siglo, la explicación de una realidad que no quedara solamente en la enunciación de los hechos, sino que trascendiera lo onírico, lo psicológico e incidiera en lo social, ya que los murales encierran los sueños de conquista y evangelización de españoles y criollos, pero son pintados por indígenas del Valle de Cuernavaca.

Bajo el concepto de semantización ${ }^{7}$ de los signos, la historia de San Felipe de Jesús y los mártires de Nagasaki recobra un nuevo sentido, lleno de intenciones frescas en el año de 1957, cuando los murales fueron descubiertos y restaurados dentro de conceptos estéticos propios del siglo $\mathrm{XX}, \mathrm{y}$ en la efervescencia ideológica y social renovadora de la Iglesia Católica impulsada por Monseñor Sergio Méndez Arceo.

Literatura y pintura dan testimonio de las historias, las cuestionan, nos proporcionan miradas diferentes, sentidos ocultos o manifiestos en los que no habíamos reparado. En el barbecho de sus

\footnotetext{
${ }^{5}$ U. Eco. La estructura ausente. Barcelona, Lumen, 1980; A.J. Greimas. Semántica estructural, Madrid, Gredos, 1976.

${ }^{6}$ En estudios lingüísticos y semióticos se considera un primer paso en la investigación reunir un conjunto, con la mayor variedad posible de enunciados o textos, donde se aprecien constantes significativas para el estudio que interesa. A estos conjuntos se les llama corpus. Al interrogarse sobre ellos, se localizan las regularidades y se describen ordenada y sistemáticamente. De esta manera, el corpus no es un mero inventario, sino la fuente de información más valiosa del investigador.

${ }^{7} \mathrm{H}$. Beristain define el concepto semantización como el proceso que convierte en discurso la lengua, al hacer uso de ésta el hablante, apropiándosela y actualizando en cada momento una de sus alternativas semánticas posibles. Diccionario de retórica y poética. México, Porrúa, 1985, p. 453.
} 
propios caminos, mediante lenguajes misteriosos e inconclusos, el arte nos acerca considerablemente a la verdad. ${ }^{8}$

El tiempo es, en alguna de sus facetas, cuestión de lenguajes; va unido a la temporalidad, la duración, la frecuencia, el orden de las acciones de los actores en el proceso discursivo. La temporalidad y el tiempo se sujetan al orden de la enunciación, en lo enunciado.

Dentro del discurso narrativo, existen como verdaderos el tiempo de la historia y el tiempo del discurso. Este último se desarrolla linealmente, es morfológico, mientras que el primero cobra pluralidad de dimensiones. Estas temporalidades no siempre son armónicas, en ocasiones se producen en canon.

Las instancias temporales en discursos plásticos juegan también entre el tiempo discursivo $y$ el histórico. Sin embargo, el tiempo real en el que transcurre un texto gráfico se encuentra limitado por las formas, los planos, los recursos, los materiales, entre otras cosas. No así el tiempo histórico. La historia, en cuanto ciencia humanística, se equipara con el tiempo que se maneja en el relato, es lineal y existe en un presente perpetuo mientras dure la acción del lector.
Una temporalidad que se desarrolla en tres momentos y en tres siglos se nos presenta en los murales de Catedral. Puede decirse que la misma historia aparece en etapas distantes y distintas; es una, pero adquiere otros significados. Su interpretación depende de semiosis ${ }^{9}$ relacionadas con las intenciones del momento. Mediante estos tiempos, uno histórico que guarda el texto y otro interpretativo que se relaciona con el lector, pude delimitar el sentido.

Así, en un diálogo constante, lector y texto inician la búsqueda en el juego del tiempo. Median entre ellos la tradición y los perjuicios que nos permiten conocer cómo han evolucionado. Cuando los tiempos y los horizontes coinciden se logra realizar la lectura. Es así que esta lectura se establece por medio de la confluencia temporal.

Siguiendo a Gadamer, ${ }^{10}$ el primer horizonte de esta historia se delimita en el siglo XVI, en espacios lejanos y distintos: México y Japón. La fragua de una empresa conquistadora y la unificación de un país son los escenarios históricos. Las vidas de San Felipe de Jesús y los frailes martirizados en Nagasaki conforman historias extradiegéticas ${ }^{11}$ que aparecen apócrifamente en los murales. El segundo horizonte pertenece al momento en el que el

\footnotetext{
${ }^{8}$ La conexión de la semiótica con el arte se estableció mediante los trabajos de V. Kandinsky. Punto y línea sobre el plano. Colombia, Labor, 1994; Sobre lo espiritual en el Arte. México, CINAR, 1994; I. Osorio Romero, et. al. La tradición clásica en México. México, UNAM, 1991, entre otros.

9 Debido a que todo pensamiento se realiza mediante signos, la explicación de cada concepto se sustenta en una serie infinita de ellos, puesto que un concepto necesariamente es explicado por otro y éste a su vez por uno más, estableciéndose una secuencia infinita; a este proceso se le llama semiosis.

${ }^{10}$ H.G. Gadamer, ibid.

${ }^{11}$ La diégesis corresponde a la narración lacónica de la historia; aquellos elementos que se encuentran fuera de esta narración son extradiegéticos.
} 
mundo. En el icono, se integran constitutivamente varios sistemas. Para percibir los mensajes es necesario establecer itinerarios, recorridos perceptivos en los que el discurso lógico y el fáctico sean el resultado de una ordenación o categorización perceptiva a través de hecho lingüístico, de una gramática particular que facilite la lectura.

Al estar frente al objeto, establecemos una red de percepción corporal. Esta percepción sabe mucho más del mundo que lo que nosotros imaginamos. Existe un saber latente que me permite ver, pensar, analizar, llorar frente a los murales, porque la mirada realiza una toma de conciencia perceptiva. Éste es un proceso retrospectivo de semantización y por medio de él reconstruimos la historia.

El sentido de la historia fluctuó entre un pasado al que había que encontrar y un presente en el que los murales recobran actualidad, vuelven a hablar. Esto fue posible mediante el análisis de las formas estéticas, su contextualización en el pasado y un proceso de semantización dentro de su contextualización en el presente.

Mediante el estudio pude establecer algunas hipótesis sobre los murales: a) los defino como un texto ideológico-social, que se apega estrictamente a las narraciones que los sostienen; b) el estudio semiótico de las formas no arroja elementos consistentes que confirmen la hipótesis de que los mu- rales fueron dirigidos por un maestro oriental, sin embargo, hacen suponer que algún fraile versado en la historia y que probablemente había realizado el viaje a las islas, planeó y dirigió la obra; c) el análisis coloremático nos permite afirmar que las manos que lo ejecutaron fueron las de los tlacuilos de la región; d) cobran sentido los fines didácticos y políticos y la preocupación de los peninsulares e hijos de provincia por la reafirmación de la religiosidad de los indios; e) esta obra monumental señala un mestizaje interesante, en el que se conjugan lo oriental, lo español y lo indio: el resultado no podía ser menos satisfactorio.

El arte es un lenguaje simbólico, un metalenguaje que está íntimamente relacionado con los estilos de vida, revela el alma popular, contribuye al cambio y a la cultura. Por él podemos vislumbrar la memoria colectiva de los pueblos.

En la ciudad de Cuernavaca, que ha cambiado tanto, las pinturas reaparecen con un mensaje que contiene un sentido evangélico, que por el contexto cobra un sesgo social. Al significado místico se une el profético que le imprime la intención restauradora. El templo recobra la austeridad franciscana. Despojada la Catedral de ornamentaciones, los signos proféticos que se agregan a los murales, contribuyen a una catalización y hablan a través de sus significados isotópicos. ${ }^{14}$

\footnotetext{
${ }^{14}$ Para explicar este concepto, es necesario revisar el de isotopía, que Greimas explica, en su Diccionario de semiótica, como una línea temática o línea de significación que se desenvuelve dentro del mismo desarrollo de discurso; esta línea produce su continuidad temática, una coherencia, que permite su comprensión y conceptualización. Los significados isotópicos, son elementos que construyen un discurso particular sencillo, claro, entendible, que se organiza alrededor de una categoría semántica en particular, central y recurrente en el texto.
} 


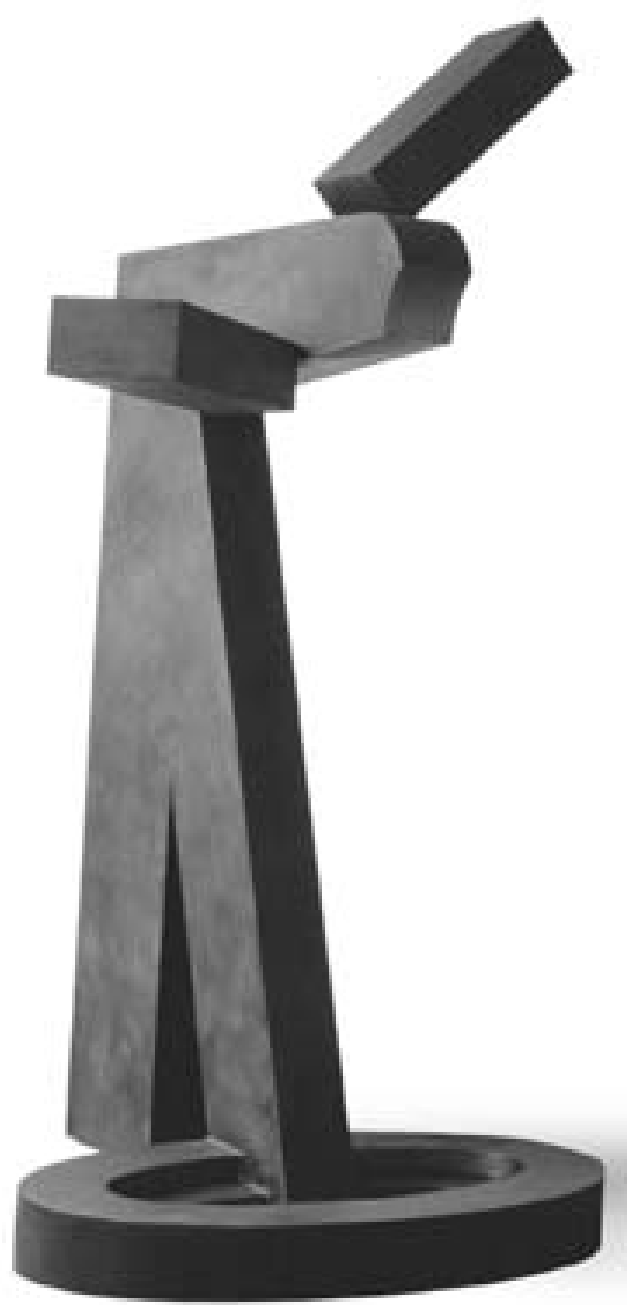

Krok, 1993 


\section{Apropiación de recursos en comunidades rurales}

- Elsa Guzmán

$\mathrm{L}$ os grupos sociales, de todos los tiempos y lugares, para subsistir y recrear sus formas de vida, llevan a cabo acciones sobre el ambiente al que tienen acceso, con lo que construyen los términos concretos de su relación con la naturaleza.

Las relaciones sociedad-naturaleza son construidas y recreadas a partir de los conocimientos que sobre la naturaleza y ambiente en general los grupos sociales sostienen, los cuales son elaborados simbólicamente dentro de una cultura en particular y llevados a procesos sociales de asignación de significados, dados por las sensibilidades, aprendizajes e interpretaciones ante la experiencia directa del individuo sobre el ambiente, teniendo como resultado percepciones propias de los recursos $^{1}$ que definen diversas actividades.

El universo cultural de los grupos campesinos contiene, entre sus ejes de desarrollo, referencias sobre el ambiente originadas desde sus experiencias sobre el entorno y su aplicación en prácticas agrícolas, de domesticación de especies animales y de recolección de productos silvestres diversos, para la obtención de recursos de consumo y uso para su subsistencia. Estas experiencias configuran, incluso, los orígenes de dichas sociedades como campesinas, cuyas bases se encuentran en el conocimiento profundo de los elementos de la naturaleza - vivos y no vivos-, de sus ciclos, gradientes, diversidades, relaciones y complejidades.

Es así como las formas de uso de los recursos e intervención en el medio que los grupos campesinos llevan a cabo son partes constituyentes de una cultura construida y cambiante, y toman forma de acuerdo con la interpretación social particular que se haga de los recursos, definida en el contexto específico de la historia y de la vida actual. Cabe enfatizar que la cultura se va constituyendo de la manera en que se percibe el entorno, al mismo tiempo que dicha percepción se configura por las formas concretas de relación y uso del ambiente. ${ }^{2}$

La relación de los grupos sociales y campesinos con el ambiente se transforma constantemente, y el sentido de los cambios está marcado por un conjunto de factores tales como las transformacio-

\footnotetext{
${ }^{1}$ El concepto de percepción ha sido trabajado por L. Arizpe, M. Velásquez y F. Paz. Cultura y cambio global: percepciones sociales sobre la deforestación en la selva lacandona. México, Porrúa-CRIM-UNAM, 1993; posteriormente por E. Lazos y L. Paré. Miradas indígenas sobre una naturaleza entristecida. Percepciones del deterioro ambiental nahua del sur de Veracruz. México, IIS-UANM-Plaza y Valdez, 2000.

${ }^{2}$ M. Redclift. "A nuestra propia imagen: el medio ambiente y la sociedad como discurso global", en L. Arizpe. Dimensiones culturales del cambio global. México, CRIM-UNAM, 1997.
}

- Profesora-Investigadora, Facultad de Ciencias Agropecuarias 
nes de la condición de los recursos, la acumulación y pérdida de conocimientos y experiencias, el acceso e intervención sobre los mismos, la percepción que la gente tenga sobre ellos, el papel o función que el uso de los recursos tiene en el desarrollo, por mencionar algunos. ${ }^{3}$

Los campesinos, en su actividad cotidiana y productiva, llevan a cabo sistemas agrícolas que vinculan aspectos sociales, económicos, rituales y ambientales; asimismo, mediante dichos sistemas configuran sus propias estrategias de reproducción y establecen una serie de relaciones con diferentes grupos sociales a través de múltiples intercambios económicos y culturales.

\section{Recursos naturales y productivos}

En México la historia campesina se ha reproducido desde un lugar desventajoso frente a la sociedad y a los distintos grupos de poder. Esta condición se encuentra presente y de alguna manera forma parte del acceso y uso de los recursos naturales y productivos que los campesinos mantienen, moldeando las relaciones que sobre ellos se conforman.

En nuestro país se ha impuesto una transformación sustantiva de los procesos económicos y sociales a partir de la segunda mitad del siglo XX, dirigida por el principio de modernización, gestada en los países desarrollados, basada en la investigación científica y tecnológica, y que actualmente forma parte del complejo de procesos denominado globa- lización. Estas influencias han trastocado todos los ámbitos de la vida del país, particularmente al sector agropecuario.

En el transcurso de las últimas décadas la sociedad mexicana ha pasado de ser predominantemente rural a urbana; la tecnología moderna ha transformado los patrones y prácticas productivos; los mercados rurales se han polarizado; la pobreza rural se ha acentuado; se intensifica el movimiento de la población del campo a la ciudad y al extranjero; las urbes crecen sobre espacios dedicados anteriormente a la agricultura, ganadería y silvicultura, procesos que han modificado a las comunidades campesinas y al paisaje rural.

En cuanto a los ecosistemas y las maneras de intervención sobre los recursos naturales, se distinguen usos de los recursos naturales en función de la obtención de máximas ganancias económicas, teniendo como consecuencia un acelerado deterioro y la erosión de especies biológicas y recursos en general. Igualmente, como parte de las transformaciones en el ámbito rural, el crecimiento de las urbes y la preponderancia de los sectores económicos industriales y de servicios han llevado a cambiar el uso y han afectado el estado de los recursos rurales, representando fuertes presiones y espacios de conflicto que comprometen la viabilidad y la redituabilidad de las actividades económicas rurales y modifican la vida rural en general.

\footnotetext{
${ }^{3}$ R. Rosaldo. Cultura y verdad. Nuevas propuestas de análisis social. México, Grijalbo, 1989.
} 
Estos cambios, en términos generales, se han encaminado hacia mayores dificultades para garantizar su subsistencia y sobre todo hacia el deterioro de sus recursos, de manera que los términos de relación actual con el ambiente se vuelven más comprometidos, ya que se han puesto en juego factores externos, como son nuevos sujetos que los disputan y los procesos de deterioro que no se contemplaban anteriormente.

Las comunidades campesinas en las condiciones actuales se han ido adaptando a las nuevas condiciones y a las pautas de desarrollo global, participando e interactuando en sectores y procesos en los que antes no lo hacían o lo hacían de manera limitada, al mismo tiempo que adecuan sus experiencias y conocimientos sobre los recursos naturales a las posibilidades y restricciones actuales, sin que hasta el momento hayan desaparecido las actividades primarias ni el uso de dichos recursos.

Podemos mencionar, por ejemplo, que la producción del maíz se mantiene actualmente como una vocación actual y extendida entre los campesinos de nuestro país. El destino para autoconsumo y la multiutilidad que se le da a la planta predomina en las familias y pueblos como parte de las estrategias de reproducción, que incluyen tanto actividades diversas locales de recolección y producción agropecuaria para venta de productos o para su autoabastecimiento, como actividades fuera de sus comunidades, regiones e incluso del país para generar ingresos que desde sus ámbitos originales no logran. ${ }^{4}$

Es así como las actividades agrícolas continúan formando parte de la vida actual de las comunidades campesinas, aunque no sean las únicas y quizá en múltiples casos tampoco las principales. Sin embargo, los recursos naturales que sustentan estas actividades se mantienen como factores básicos para su realización. De esta manera, se distingue a la tierra y al agua como dos elementos, entre el conjunto de recursos naturales, que a su vez son sustento para el desarrollo de la vida natural y para la producción agropecuaria, es decir, forman la base de los ecosistemas, así como de los agroecosistemas.

El ambiente en estos términos es mucho más que naturaleza, es soporte para la reproducción social y cultural de los pueblos que subsisten de él. Es decir, está involucrado el factor desarrollo. La relación de la cultura con el ambiente define variables sobre el desarrollo que se construye sobre los términos posibles de sustentabilidad, las limitaciones que se imponen ante los cambios y deterioro actual de los recursos. Esta dimensión amplia de los recursos se plantea indispensable, especialmente cuando se reconoce que el uso implica maneras específicas de decisión y definición de criterios y objetivos para la utilización, beneficios posiblemente diferenciados dados por mecanismos de control y restricción de acceso a los recursos.

\footnotetext{
${ }^{4}$ Vania Salles menciona como ingreso total al conjunto de ingresos producto de una multiactividad que conforma el sustento. V. Salles. "Una discusión sobre las condiciones de la reproducción campesina", en O. Oliveira, M. PepenLehaulleur y V. Salles. Grupos domésticos y reproducción cotidiana. México, Colmex-Porrúa, 1989.
} 
Los componentes de los procesos de uso de los recursos, si bien hablan de actividades, gestión, acuerdos, control y reglas para llevarlos a cabo, en realidad dependen de las condiciones para el acceso a dichos recursos. Este acceso está enmarcado por la historia regional, las experiencias comunitarias, las intervenciones de distintos agentes, disputas entre pueblos, etcétera; es decir, contiene el centro de las relaciones sociales que se sostienen en el uso de los recursos.

De esta manera, como se señala, el acceso de las comunidades campesinas al agua y a la tierra para su subsistencia y recreación de formas de vida implica tanto la relación y la percepción que estas comunidades mantienen con los recursos, como las relaciones con un conjunto de grupos sociales involucrados con quienes han venido compartiéndolos, disputándolos o resistiendo.

\section{Tierra, agua y desarrollo comunitario}

La tierra y el agua -si bien pueden ser reconocidos como recursos naturales- son igualmente recursos productivos estratégicos para la producción agrícola y recursos culturales para el sostenimiento del territorio de las comunidades campesinas. El conjunto de recursos naturales, reconocidos como todos los elementos bióticos de la naturaleza (plantas y animales) y abióticos que son utilizados por las culturas humanas para diversos fines alimentarios, energéticos, medicinales, rituales, instru- mentales (construcciones), ornamentales o como materia prima para la transformación hacia procesos industriales con estos $u$ otros fines, tiene como sustento al agua y a la tierra. Cada uno de estos dos recursos tiene particularidades que versan entre los significados biológicos, productivos y culturales; se presentan como contenedores de las interfases entre lo ambiental y lo cultural.

El término tierra tiene múltiples acepciones. Primeramente, podemos hablar del sentido material como soporte físico de la vida de plantas, animales, asiento de pueblos, entre otros; esta cualidad se encuentra asociada al soporte biológico, pues es donde se llevan a cabo procesos químicos y biológicos para la vida que sostiene; también cumple una función en el sentido productivo, como suelo, en tanto da lugar al desarrollo de cultivos agrícolas, actividades pecuarias y silvícolas.

Pero tierra tiene otros significados, históricos y culturales. La tierra es el espacio de los pueblos, sobre ella se han construido significados simbólicos y prácticas que la han conformado como territorio. ${ }^{5}$ Esta acepción incluye al paisaje como tal, las habitaciones, las parcelas, los caminos, el monte para recolección de uso común; contiene igualmente largas historias, experiencias, recuerdos, transformaciones cuyo reconocimiento ha generado acciones de defensa, así como procesos de pertenencia, apegos, identidades, en fin, el reconocimiento que la gente tiene como mi tierra.

${ }^{5}$ G. Giménez. Territorio y Cultura. México, Universidad de Colima, mimeografiado, sin fecha. 
Los pueblos actuales cuentan con tierra como producto del proceso de reparto agrario iniciado en la década de los años veinte en México. Esto les ha posibilitado establecer en ella una actividad agrícola, propia de su vocación cultural. Este vínculo se ha modificado a lo largo de las décadas, pues mientras se mantiene por parte de unos grupos la demanda permanente de petición o ampliación de tierra, para quienes han logrado contar con ella és ta ha sido la base de su seguridad alimentaria, a pesar de no ser suficiente en algunos casos; otros buscan venderla o rentarla para poder comprar distintos bienes o posibilidades. Así, la tierra en este sentido confronta historias culturales, necesidades inmediatas y proyectos de distinta índole.

Por su parte, el agua también carga un complejo de elementos materiales y simbólicos; representa el insumo básico de la vida, el disolvente universal de las reacciones químicas, sin ella no hay subsistencia de ningún tipo. Es el soporte y medio de una parte de la vida de la Tierra, que incluye una gran diversidad de especies animales y vegetales con usos fundamentales para muchos grupos, incluyendo campesinos y pescadores, tanto de mar como continentales.

De igual modo, al tenerse como fuente de agua las lluvias y los cuerpos naturales, el conocimiento de sus ciclos y gradientes en el ambiente ha sido parte conformante de las culturas campesinas, e incluso ha sido forjador de cultura. El manejo y uso del recurso implica conocimiento y experiencia amplia y detallada, para usarla dentro del temporal de lluvias, manejar escurrimientos, almacenarla, conducirla, etcétera, pero también ha despertado grandes disputas por el control y ha estado en medio de historias de diferenciación social.

Las limitaciones hídricas principales en la actualidad se refieren a la escasez y a la contaminación, y en los dos casos tienen que ver las disputas entre los usuarios rurales y con otros sectores de la sociedad (ciudades, industrias, fraccionamientos) y entre los pueblos mismos.

La tierra y el agua constituyen dos elementos básicos para la actividad agrícola campesina. Sin ellos no se podría llevar a cabo y aun en condiciones de escasez e incertidumbre son utilizados para efectuarla. Es decir, la agricultura se ha adecuado a las limitaciones y posibilidades de los recursos, pero también a las transformaciones constantes, debido a que representa la seguridad alimentaria de los grupos campesinos y la recreación de espacios culturales que posibilitan la reproducción campesina frente a una estructura social en la que ocupa lugares de marginación, por lo que se puede considerar que, incluso, gesta espacios de poder.

\section{Morelos}

El problema de los recursos ambientales se centra, actualmente, en las posibilidades, limitantes o tendencias que marcan o definen el desarrollo en cada región, y en particular en las comunidades campesinas, poniéndose en juego un conjunto de factores como las potencialidades materiales y biológicas de los propios recursos naturales, las historias de uso, las culturas construidas, las percepciones de las comunidades campesinas y los procesos 
de apropiación que se confrontan en las relaciones sociales en cuestión.

De esta manera, el agua y la tierra, como recursos naturales y productivos para las comunidades campesinas, son asunto tanto de abordajes antropológicos desde el acercamiento a los sujetos y su relación cultural con el ambiente y recursos; como del enfoque de desarrollo rural, como visión interdisciplinaria que centra específicamente a los grupos y comunidades campesinas como los sujetos del desarrollo regional y local, quienes se encuentran vinculados a otros actores mediante relaciones sociales que definen el uso y el acceso a los recursos naturales y productivos.

Se requiere, entonces, reconocer qué actores están involucrados con el uso y el estado actual de los recursos tierra y agua, cuáles son los ejes de encuentro o disputa, los elementos de poder de cada uno, y profundizar en las posibilidades y el acceso a los recursos que están definiendo, en especial, las comunidades campesinas. Este enfoque concibe a los territorios como contenedores de relaciones sociales en el uso de recursos naturales, desde donde se plantea el sentido actual del desarrollo, en tanto el uso y procesos sobre los recursos definen posibilidades y limitaciones estratégicas para el ejercicio y poder de ciertos actores.

Por ejemplo, en Morelos en cada región los actores sociales se confrontan de acuerdo con los intereses dirigidos por el acceso a los recursos disponibles y a las condiciones de desarrollo construidas. En términos muy generales, a manera de ilustración, podemos decir que:
En la región de los Altos de Morelos (Tlalnepantla, Tlayacapan, Totolapan, Atlatlahucan y Yecapixtla) existe una fuerte presión a los recursos dirigida por el crecimiento de fraccionamientos de uso urbano-residencial que disputan la tierra, al ir induciendo el cambio de uso del suelo, pero igualmente definen acceso y restricción al agua hacia otros usuarios, como las comunidades campesinas.

Hacia el centro y centro sur, entre los municipios de Yautepec, Tlaltizapan, Ayala y norte de Tlaquiltenango, el eje de la disputa es el agua, ya que es la región con mayor concentración de agua superficial y freática, en donde se le ha dado prioridad a usos turísticos y privados, que restringen la disponibilidad de agua en el balance general del sistema hidrológico del estado.

En el oriente, entre los municipios de Tetela del Volcán, Ocuituco, Zacualpan, Temoac, Jantetelco y Jonacatepec, existe una fuerte disputa entre los pueblos de la cuenca del río Amatzinac por el agua de la corriente fluvial de la región, que se sobrepone a las desigualdades en el acceso a la tierra y a las posibilidades de usarla, ante el riego posible.

En la zona de riego del oriente, entre los municipios de Cuautla, Ayala y Jonacatepec, el acceso a este recurso dirige la presión de comerciantes por rentar las tierras ejidales para el cultivo comercial de hortalizas, desencadenando relaciones sociales entre empresarios, intermediarios, campesinos, jornaleros, y otros.

En el poniente de Morelos, la minifundización parcelaria y la dependencia del agua a la disponibilidad de acuerdo con el temporal, dirigen las 
posibilidades productivas y las necesidades de multiactividad para sostener el desarrollo de las comunidades.

En el sur del estado, así como en Huitzilac -al norte-, municipios pertenecientes a reservas de la biosfera, los procesos de acceso a los recursos pasan por las concepciones de conservación que se dan entre las reglamentaciones oficiales y las necesidades y decisiones de las comunidades.

El crecimiento urbano en la región CuautlaCuernavaca-Jojutla (municipios de Temixco, Cuernavaca, Cuautla, Jiutepec, Emiliano Zapata, Xochitepec, Zacatepec y Jojutla) está dirigiendo la disponibilidad y uso de suelo y agua e induciendo transformaciones importantes en las actividades y relaciones entre los habitantes en las zonas rurales aledañas a éstas.
El planteamiento de cada caso puede ser el eje para indagar las condiciones de la relación entre las comunidades campesinas y los recursos naturales y productivos, con una perspectiva amplia que contemple las condiciones generales de los recursos, las posibilidades de acceso, las visiones y la transformaciones que existe desde las comunidades campesinas frente a conflictos específicos por los recursos. Problematizar de esta manera nos puede dar pautas para entender las tendencias, potencialidades y alternativas frente a las limitaciones de acceso o los procesos de deterioro existentes en las comunidades campesinas, de tal manera que se puedan proponer alternativas para que los recursos naturales puedan erigirse como elementos productivos estratégicos que contribuyan a la seguridad, subsistencia y desarrollo de los grupos. 


$$
1
$$




\title{
La investigación interdisciplinaria en diseño arQuitectónico
}

\author{
- Andrea Martín \\ Juan de Dios González
}

A lo largo de los dos últimos siglos en la arquitectura, como en otras prácticas profesionales liberales como la medicina, el derecho y la ingeniería, se ha venido produciendo una separación creciente entre sus diferentes funciones. Baste citar que muchas de las funciones implicadas en el diseño de edificios - tradicionalmente correspondientes a la arquitectura- se han independizado, con el consiguiente desarrollo de especialidades y profesionales dedicados a esas áreas. En el derecho ha ocurrido un proceso similar: se han separado de las facultades de jurisprudencia varias disciplinas tales como la sociología, la ciencia política, las relaciones internacionales y el trabajo social.

Con el desarrollo de la teoría de las estructuras, la ingeniería se convirtió en una práctica independiente, y junto con los ingenieros calculistas, surgieron también los de construcción, los de control térmico, de ventilación, acústicos o eléctricos. ${ }^{1}$ Así, por un lado, la función del arquitecto se ha ido restringiendo quedándole fundamentalmente aquellas tareas del diseño de los espacios que son más difíciles de ser cuantificadas; por otro, los retos que el arquitecto tiene que resolver en la actualidad, además del proceso mismo de diseño ${ }^{2}$-tales como la satisfacción de necesidades biopsicológicas y sociales del hombre relacionadas con nuestra interdisciplina científicoartística y, las implicaciones que las relaciones hombre-edificio-entorno tienen sobre el diseño-, han adquirido nuevo valor y se han hecho mucho más complejo para su comprensión y análisis.

En la segunda mitad del siglo XX surgieron nuevas disciplinas y técnicas que apoyan el diseño arquitectónico con grandes logros técnicos y gran avance de la investigación aplicada al diseño. Sin embargo, para enfrentar los retos del nuevo milenio necesitamos salir de nuestras viejas disciplinas para lograr una investigación multidisciplinaria. ${ }^{3}$

\section{La investigación}

A partir del siglo XX se desarrolla la investigación aplicada en diseño y se formalizan escuelas especializadas. En los años veinte se fundaron la Bauhaus y la Deutscher Werkbund, que buscaban un racionalismo en la actividad proyectual. El diseño debía contener una serie de parámetros objetivos

${ }^{1}$ G. Broadbent. Diseño arquitectónico. Arquitectura y ciencias humanas. Barcelona, Gustavo Pili, 1976. p.13.

2 "El proceso de diseño es la secuencia íntegra de acontecimientos que lleva desde la primera concepción de un proyecto hasta su realización total”. G. Broadbent, et al. Metodología del diseño arquitectónico. Barcelona, Gustavo Gili, 1971. p. 22.

${ }^{3}$ F. Pérez. Ciencias y artes para el diseño. UAM-X. México, 1998, p. 51. 
(adaptación al medio ambiente, función, estandarización de los materiales), subrayando la importancia de sus funciones estructurales con soluciones concretas y económicas.

Durante la Segunda Guerra Mundial se formaron grupos multidisciplinarios (ingenieros, diseñadores industriales, psicólogos, fisiólogos, estadísticos) para rediseñar armas, de modo que éstas pudieran ser utilizadas de forma más eficiente por soldados de características muy distintas de diversas razas y nacionalidades. Así surgió el Operational Research (Investigación Operativa, I.O.), que se desarrolló en Inglaterra a partir de una visión científica aplicada a la solución de los problemas, con particular referencia a la matemática de las probabilidades. Posteriormente, la búsqueda de métodos que permitieran el manejo más objetivo de los factores que influyen en los proyectos llevó a un acercamiento con la ingeniería, con el método científico y con el I.0. ${ }^{4}$

La idea de identificar distintos intereses de diferentes especialistas y combinarlos para perseguir un mismo objetivo, contribuyó a la formación de otros grupos interdisciplinarios y al desarrollo de otras disciplinas como en el caso de la ergonomía (en 1949 se formó la Ergonomics Research Society con anatomistas, fisiólogos, funcionarios médicos de la industria, higienistas industriales, ingenieros de iluminación y otros especialistas). ${ }^{5}$

Alrededor de 1956 los profesores de la escuela de Ulm, la Hochschüle für Gestaltung, se libraron del legado de la Bauhaus para orientarse hacia una línea más rigurosa y científica.

Al iniciar los años sesenta "varios hechos indicaban la emergencia de una nueva metodología de diseño, como una disciplina de derecho propio"6 y durante esta década y la siguiente se dio gran auge en la discusión y proposición de los métodos de diseño desde varios institutos y universidades y se formalizaron algunos grupos de profesionistas con el propósito de buscar mejores caminos o estrategias para resolver el problema del diseño y de la construcción de viviendas en gran escala. Tal es el caso en 1964 del Stichting Architecten Research, una fundación de arquitectos holandeses para la investigación en su campo.

Hasta la fecha se han formado gran variedad de grupos, algunos de los cuales operan internacionalmente, centrados en el diseño arquitectónico con distintos enfoques e intereses particulares. Sin embargo, pocos grupos han tenido éxito en provocar la integración en el mundo de la investigación teórica y la práctica, sobre todo en una investigación más compleja y multidisciplinaria.

\footnotetext{
4 "La aplicación de las técnicas I.O. a la toma de decisiones administrativas, al final de los cincuentas, fue un modelo que los pioneros de los métodos de diseño usaron para justificar el desarrollo de nuevas técnicas para la toma de decisiones en el proceso de diseño". N. Cross, en L. Rodríguez Morales. Para una teoría del diseño. México, UAMAzcapotzalco-Tilde editores, 1989, p. 30.

${ }^{5}$ G. Broadbent. Diseño arquitectónico... op. cit., p.245. “En esta segunda época (1962-1966) -la época del diseño científico- de Ulm, el arte y la intuición sobre los que Bill había puesto acento, fueron reemplazados por la metodología analítica".

"Ibid., p. 245.
} 
Podemos afirmar que el caso de la pobreza de la investigación en diseño arquitectónico en México se demuestra por la falta de éxito global interdisciplinario significado por las escasas aportaciones a la arteciencia arquitectónica universal. Esto pareciera que en Latinoamérica es la regla y no la excepción.

Esta falta de aportaciones mexicanas al desarrollo del conocimiento artecientífico arquitectónico universal, puede tener su origen en algunas de las siguientes causas:

el divorcio entre la actividad que desarrollan los arquitectos dominantemente prácticos (los que se dedican a la práctica profesional y que confunden generalmente a esta creativa actividad de aplicación de conocimientos, técnicas y experiencias con la investigación arteciencia arquitectónica de frontera) y la que realizan los arquitectos fundamentalmente teóricos (los que se dedican a la academia);

la separación, incomprensión o incomunicación entre lo que algunos autores identifican como artisticidad y cientificidad -conocimientos, intuiciones, imaginación, creatividad, métodos, percepciones, sensibilidades, reflexiones, actitudes y actividades que se necesitan conjugar en la arquitectura- genera mucha confusión en la investigación en diseño arquitectónico;

en los escasos grupos de investigadores en este campo, generalmente faltan objetivos comunes $y$ valores artísticos y científicos que combinen intereses y acciones de diferentes especialistas;

además, nos encontramos con que los arquitectos que se dedican a la práctica profesional, están sometidos a los tiempos y contratiempos políticos y económicos de la demanda de obras. También están expuestos a una constante presión para la experimentación empírica o aplicativa, generada por el rápido desarrollo de nuevas tecnologías y de materiales de construcción.

Esta dinámica difícilmente propicia el análisis y la evaluación posterior de esta experimentación, sobre todo la que se refiere al uso y operación de los edificios. Las evaluaciones que generalmente se llevan a cabo se hacen desde un enfoque económico o constructivo.

Los arquitectos que se dedican fundamentalmente a la teoría y a la enseñanza de la arquitectura, frecuentemente disponen de más tiempo y recursos para hacer investigación en diseño arquitectónico, pero, al contrario de los que ejercen la arquitectura como una profesión liberal, tienen pocas oportunidades para experimentar en la práctica.

La escasez de recursos para evaluar y difundir algunos de los resultados de esta experimentación minimiza el impacto que éstos pudieran tener en el mundo real. Estas investigaciones se traducen, la mayoría de las veces, en ejercicios meramente académicos sin aportaciones teóricas o prácticas en el campo de la arquitectura.

En la parte científica y cuantitativa del diseño arquitectónico ha habido logros técnicos cada vez más sofisticados, derivados de la investigación operativa y del análisis de sistemas; sin embargo, en la parte artística y creativa estas técnicas cualitativas no resuelven el problema fundamental consistente en integrar ciencia y arte en el quehacer arquitectónico de frontera, dando por resultado espectaculares avances 
lidad humana que es la base de todo conocimiento y que sus marcos teóricos actúan como prisiones que les impiden apreciar la realidad. ${ }^{9}$

La dictadura de la razón es combatida por el conocimiento artístico, mientras que, por su parte, el científico lucha o cree combatir al imperio de los engañosos sentidos o de la considerada como la loca de la casa: la imaginación o fantasía.

Consideramos que ello es un falso problema, pues ambos se pueden enriquecer y apoyar mutuamente. De este modo, sin creatividad científica no puede haber avances en las ciencias y ésta exige imaginación e intuición aparte del trabajo metódico y disciplinado.

Una carencia que afecta a la investigación es lo epistemológico, consistente en el que se confunda la obra, ser, cosa, ente, edificio, departamento, casa, residencia o espacio arquitectónico o la actividad arquitectónica con el conocimiento de lo arquitectónico, el no distinguir el ser del conocer de ese ser, para no mencionar la ignorancia de lo epistémico, es decir, el saber o conocimiento del conocimiento arquitectónico. Subrayamos que se confunde el ser con el conocer de nuestro campo. Así es como se pretende - por ignorancia o resistencias conscientes o inconscientes- desaparecer el tercer nivel cognitivo o epistémico, con lo que la creatividad artecientífica se ve impedida.
También se confunde interdisciplinariedad con multidisciplinariedad. Mientras que en la primera existe una comprensión y enriquecimiento cognitivo mutuo, en la segunda sólo estamos ante la presencia de diversas disciplinas que actúan sobre objetos, sujetos o procesos; sobre los materiales, mas no sobre el hombre y su capacidad lógica y reflexiva, sin que la multidisciplinariedad permita que se genere un espacio cognitivo común.

Ocurre en el caso de los arquitectos dominantemente prácticos que necesitan recurrir a diferentes especialistas para poder llevar a cabo la construcción de sus obras, sin que se construya el espacio interdisciplinario o transdisciplinario cognitivo, ${ }^{10}$ quedándose cada experto preso de su campo disciplinario.

Gremialmente, lo contrario sería lo que en tiempos de guerra se llama fraternizar con el enemigo, lo que es castigado por los códigos militares con severas penas y el rechazo social.

La construcción de lo interdisciplinario y lo transdisciplinario encuentra en la sociología del conocimiento, lo epistémico o el conocimiento de tercer momento o nivel, ${ }^{11}$ un apoyo para desarrollar investigación en la arteciencia arquitectónica.

En la práctica liberal profesional se tiene que trabajar de manera multidisciplinaria, debido a las

\footnotetext{
${ }^{9}$ Arthur Kissinger escribe en sus Memorias que antes de realizar las pláticas secretas con los dirigentes vietnamitas en París, consultó a los máximos expertos sobre guerra, historia e idiosincrasia de sus adversarios y para su sorpresa se encontró con que fue el escritor Andre Malraux quien le proporcionó la mejor asesoría, y así, escribió: “es sorprendente cómo un artista gracias a su intuición puede superar al intelectual mejor informado".

${ }^{10}$ Empleamos a este último concepto bajo el supuesto que contiene a lo epistémico o metacognitivo.

${ }^{11}$ En E. Lamo de Espinosa, et al. La sociología del conocimiento y de la ciencia. Madrid, Alianza Universidad, 1994, pp. 19-20.
} 
exigencias que plantea todo el equipo que participa tanto en el diseño de un edificio como en su construcción (ingenieros calculistas, electricistas, técnicos y expertos de control de clima, decoradores, entre otros).

Las técnicas particulares para optimizar el trabajo en equipo generalmente son desconocidas por unos y por otros, los que sólo pueden ver los resultados finales pero no conocerlas y menos dominarlas.

Para mejorar la calidad de la investigación en diseño arquitectónico en la universidad, debemos tener programas de superación para impulsar el trabajo interdisciplinario y transdisciplinario en equipo.

Podemos señalar como medio eficaz para impulsar lo anterior empezar por identificar aquellos intereses comunes que existen entre investigadores de distintas disciplinas, las actitudes que se presentan, y el conocimiento mutuo que se tiene sobre las ciencias y artes del diseño y las ciencias sociales.

Afectan de igual manera los prejuicios, los mitos y las fantasías de cada ciencia junto con sus paradigmas, así como los prejuicios o recelos con que unos a otros nos observamos y calificamos, y el cómo y por qué nos evaluamos o autoevaluamos.

Ello se aplica tanto a los que hemos identificado con fines académicos como arquitectos, tanto prácticos como teóricos, dentro del mismo equipo de trabajo.

La existencia de distintos tipos de investigación y alcances dentro del equipo de investigación, se puede enriquecer de acuerdo con los intereses personales y la experiencia de cada investigador como miembro de una comunidad científica.

El paso de un grupo de trabajo a otro como grupo científico implica como prerrequisito un cambio de actitud, empezando por la manera como se valora el conocimiento: mientras en el primer grupo éste se convierte en un instrumento de trabajo, en el segundo es una materia prima que empieza con los últimos conocimientos de frontera para desde ahí comenzar la labor creativa.

Lo importante es producir conocimientos; no sólamente proyectar, diseñar o construir edificios, sino construir conceptos, categorías, metodologías y marcos teóricos que permitan tanto el avance del conocimiento como el de la práctica arquitectónica y del diseño. 


\section{La administración educativa de los menores infractores}

- Ladislao Reyes

$\mathrm{L}$ a multiplicidad de problemas que configuran la administración educativa del menor infractor en México, constituye un vasto tema de estudio que reclama mayores acercamientos analíticos desde los distintos campos del conocimiento. Los incipientes esfuerzos de interpretación a los cuales se suma este trabajo, ${ }^{1}$ requieren ser sustancialmente incrementados si se desea mejorar en algún sentido la compleja situación que se vive en México en materia de administración educativa de los menores infractores.

Son escasos los estudios sobre el proceso educativo de los menores infractores. Quizá debido a que éstos son atendidos por la Secretaría de Seguridad Pública a nivel federal y en las entidades por las instancias de readaptación social. Es un ámbito donde la Secretaría de Educación Pública tiene escaso poder de decisión.

\section{De lo educativo a lo punitivo}

Históricamente eran asunto de la administración educativa las casas de maternidad y de niños expósitos hasta las universidades, colegios, seminarios, prisiones y correccionales. Así, la Secretaría de Estado y del Despacho de Relaciones Interiores y Exteriores era una institución centralizada que se hacía cargo de los diferentes y muy diversos cometidos del gobierno, como es el control del Ministerio de Instrucción y Justicia.

En el Ministerio de Instrucción y Justicia, se encontraba una gran variedad de órganos administrativos, como las Escuela Básica y la Escuela Correccional; entes limitados que pretendían la formación de menores para transmitir valores y cultura.

Las primeras disposiciones formales que trataron de controlar socialmente las conductas del menor en México se remontan a 1825. En ellas, se establecía implícitamente que la educación de los menores estaba a cargo de la familia y de los profesores. Así, en el Bando de policía y buen gobierno del 7 de febrero de 1825 se instituyó en su numeral 18 que: "También se le exigirá irremisiblemente o se le dará un destino correccional por el alcalde o regidor del cuartel, a cualquier persona de ambos sexos que contra las reglas del pudor y la

\footnotetext{
${ }^{1}$ La Administración de Justicia de Menores abarca el Consejo de Menores (órgano jurisdiccional) y los Centros de Tratamiento (donde se intenta adaptar a los menores). Es pertinente aclarar que aquí sólo se presenta una parte de la Administración de Justicia de Menores infractores: Las Escuelas Correccionales, actualmente Centros de Tratamiento.
}

- Profesor-Investigador, Facultad de Derecho y Ciencias Sociales 
decencia, se ensuciare en las calles, plazuelas y parajes públicos, como también contra el que en ellos pusiere o derramare vasos de inmundicia; haciéndose extensiva esta providencia a los padres de familia y maestros o maestras de escuelas o amigas, que no impidan a los niños salgan a ensuciarse en las calles, por cuyo descuido se les hace responsables, y sufrirán la exacción de la misma multa". ${ }^{2}$

Existen indicios claros de que en marzo de 1828 se creó el primer tribunal a cargo de las infracciones de menores, que no sólo juzgaban precisamente las violaciones al código penal, sino que sancionaba conductas antisociales, como la vagancia y las faltas a la moral cometidas por los menores. El proceso para juzgar al menor se llevaba a cabo en una sala especial llamada Sala Capitular, y por lo general eran procesos que no se realizaban públicamente. El órgano jurisdiccional se llamaba "Tribunales de vagos en el distrito y territorios", que fueron quizá el antecedente de los tribunales de menores, este tribunal era similar - al menos jurídicamente- a un promotor fiscal, persona que realizaba las tareas de un “Juez paternal”. La vagancia ${ }^{3}$ era uno de los múltiples delitos que perseguía la Administración de Justicia de menores, y por lo general no existían casas de corrección, ${ }^{4}$ como se puede apreciar en los bandos que emitía la Administración Pública. El lugar más común donde se recluía al menor para pagar su delito era la prisión.

\section{Escuela correccional}

La original Secretaría de Estado y del Despacho de Relaciones Interiores y Exteriores se fue dividiendo en múltiples secretarías, con tareas administrativas diversas y especializadas. Se creó una Secretaría de Justicia e Instrucción Pública. Sin embargo, el menor infractor quedaba bajo la tutela de los órganos jurisdiccionales que aplicaban penas punitivas, sin ninguna diferenciación entre adultos y menores. Incluso, purgaban sus condenas en los mismos lugares. Estas condiciones fueron percibidas por diferentes personas preocupadas por el menor. ${ }^{5}$ En 1841, Manuel Eduardo Gorostiza estableció una casa correccional anexa al Hospital de Pobres, con fondos de la administración municipal.

El 7 de diciembre de 1871, el Congreso expidió un decreto con el objeto de que se pusiese en observancia un Código Penal, el cual, en el artículo 13 de su ley transitoria, ordenaba que los establecimientos conocidos con los nombres de

\footnotetext{
${ }^{2}$ M. Dublán y J.M. Lozano. Legislación Mexicana. Tomo I. México, Espasa Calpe, 1988, p. 766.

3 J.L. Soberanes. "Memoria presentada el 22 de mayo de 1830", en Memorias de la Secretaría de Justicia. México, UNAM, 1997, p. 70. El secretario Juan Ignacio Espinoza escribe que "los vagos son unos verdaderos zánganos y polilla de la república. Todos los legisladores los han perseguido, porque siendo ociosos de profesión están siempre dispuestos a toda clase de desórdenes contra la sociedad en que viven".

${ }^{4}$ Ibid.

5 J.L. Soberanes. “Memoria presentada el 22 de mayo de 1830”, op. cit., p. 57.
} 
Tecpan de Santiago ${ }^{6}$ y Hospicio de Pobres fuesen destinados para la corrección penal y para la educación correccional de los jóvenes delincuentes. ${ }^{7}$ Formalmente, desde esta fecha a los menores se les ubicó en el sistema penal. Tan es así, que desde 1884 los menores que infringían la ley eran enviados al Ex Convento de San Pedro y San Pablo. En ese colegio, se les internaba para su reeducación, aunque menores que cometían delitos más graves eran llevados a la prisión de Belén, a donde se les encerraba con delincuentes adultos, los que pervertían en mayor grado a los menores en las trampas del robo y el asesinato. En este contexto, la administración, en sentido amplio, en noviembre de 1891 empezó a dividir sus atribuciones, modificadas por la necesidad de establecer y fortalecer sus instituciones administrativas. Las atribuciones fueron modificadas por el decreto del 8 de mayo de 1891. En esa época se definieron con mayor precisión las atribuciones especializadas de la Administración Pública; se establecieron la Secretaría de Hacienda Crédito Público y Comercio, la Secretaría de Fomento, la Secretaría de Comunicaciones y Obras Públicas, la Secretaría de Justicia e Instrucción Pública, la Secretaria de Relaciones Exteriores y la Secretaría de Gobernación. ${ }^{8}$
La multiplicidad de tareas encomendadas a la Secretaría de Justicia e Instrucción Pública no permitió que se hiciera más eficaz administrativamente. Se requirió dividirla con personal especializado para cada una de ellas, por lo que, por decreto del 16 de mayo de 1905, el ramo de la Instrucción Pública fue separado de la Secretaría de Justicia. ${ }^{9}$ Esta división administrativa tuvo como finalidad atender con mayor eficacia cada uno de los rubros de la formación de los menores. Sin embargo, los incipientes lugares donde se recluía al infante no fueron contemplados para que estuvieran a cargo de la nueva Secretaría de Instrucción Pública, a la cual le correspondía por ser menores en formación. Las razones no se encuentran inventariadas, pero suponemos que los menores que infringían una disposición no eran percibidos como niños normales que estaban en proceso de educación.

\section{La realidad}

Insertados los menores infractores en la administración de justicia, quedaron entre el umbral de lo ontológico y lo deontológico; entre finalidades reales y aparentes ${ }^{10}$ del sistema penal y no del educativo. El 30 de septiembre de $1908,{ }^{11}$ se propuso crear un órgano jurisdiccional exclusivo

\footnotetext{
${ }^{6} \mathrm{~J}$. Ma. del Castillo Velasco. Ensayo sobre el Derecho Administrativo Mexicano. México, UNAM, 1994, p. 388.

7 J.L. Soberanes. "Memoria que el encargado de la Secretaría de Justicia e Instrucción Pública presenta al Congreso de la Unión en 15 de septiembre de 1873", en Memorias de la Secretaría de Justicia. México, UNAM, 1997, p. 304.

8 Instituto Nacional de Administración Pública. La organización de la administración pública en México. México, Limusa, 1999, p. 11.

${ }^{9}$ Ibid., p. 11.

${ }^{10}$ R. King Merton. Teoría y estructuras sociales. México, FCE, 1996, p. 267.

11 J.Á. Ceniceros y L. Garrido. La delincuencia infantil en México. México, Botas, 1936. p. 19.
} 
los menores procesados y recluidos en los mencionados establecimientos.

En el mismo sentido, se buscó que fueran jueces cercanos los que juzgaran a los menores, para evitar que éstos fueran trasladados largas distancias y por consiguiente maltratados. Por ello, en la circular "número 189 expedida el 7 de Enero de 1910, dispone que las diligencias que practiquen los Jueces del ramo penal del Distrito Federal en los procesos que instruyan contra menores delin cuentes, recluidos en Establecimientos de Corrección Penal y que estén situados fuera de su jurisdicción, encomienden la práctica de esas diligencias al juez bajo cuya jurisdicción se encuentra la Escuela Correccional". ${ }^{13}$

A pesar de que el Código Penal establecía que los menores debían purgar sus penas en instituciones administrativas especiales como la Reclusión Preventiva en Establecimiento de Educación Correccional, Reclusión Preventiva en Escuela de Sordomudos y Reclusión Preventiva en Hospital, esto sólo formó parte de la teoría. Hasta 1917 fue la Secretaría de Justicia quien se hacía cargo de todo el sistema penal; esta Secretaria proporcionaba recursos humanos y materiales para el correcto funcionamiento de la Administración de Justicia. Como bien lo plantea Omar Guerrero, ${ }^{14}$ su impropia desaparición acarreó deficiencias en el servicio administrativo de justicia.
Decretada su desaparición por el Constituyente de $1917,{ }^{15}$ sus funciones fueron absorbidas por un Departamento Judicial y la Secretaría de Gobernación. Por ello, por Decreto del 1 de mayo de 1917 se sumaron a la Secretaría de Estado los negocios que habían pertenecido a la Secretaría de Justicia, y las instituciones especiales para el tratamiento de los menores infractores quedaron a cargo del Gobierno del Distrito Federal.

A partir de 1917, el sistema que atiende a los menores infractores ha pasado por diferentes Secretarías, como la Gobernación y actualmente bajo la Seguridad Pública. Los cambios para adaptar, reeducar, o formar no han cambiado sustancialmente. Las escuelas correccionales o reformatorios hoy se llaman Centros de Tratamiento, instituciones donde los procesos de educación son los mismos por años y están anquilosados; incluso se han recrudecido en prisiones de alta seguridad como los aplicados en el Centro de Atención Especial Dr. Alfonso Quiroz Cuarón.

\section{El Centro Dr. Alfonso Quiroz Cuarón}

El Centro es una unidad que brinda atención especial. Es una "prisión de alta seguridad para menores" que rompe con los objetivos de las leyes que rigen a los menores. El centro es la antítesis de la adaptación del menor. En él, se recluye en celdas a los menores infractores que son trasladados de otros

\footnotetext{
${ }^{13}$ Ibid., p. 520.

${ }^{14}$ Véase más ampliamente la obra de Omar Guerrero.

${ }^{15}$ Constitución Política de los Estados Unidos Mexicanos. Transitorio Art. 14.
} 
Centros de Tratamiento, que tuvieron principalmente problemas de conducta graves con otros compañeros o con el personal de la institución, alta agresividad, elevada posibilidad de reincidencia, alteraciones importantes del comportamiento pre-vio a la comisión de la conducta infractora, falta de apoyo familiar, ambiente social criminógeno o conducta que altere gravemente el orden del Centro.

En estos casos, el director levanta un acta administrativa y turna el caso al Consejero Técnico, mismo que rinde un informe al Comité Técnico Interdisciplinario, quien comunica al Consejo Unitario, para que resuelva si es procedente enviar al menor al Centro de Atención Especial. ${ }^{16}$ Antes de recluir al menor en el Centro Dr. Alfonso Quiroz Cuarón, se le da vista a la Unidad de Defensa de Menores, quien podrá impugnar la decisión.

Recluido el menor en el Centro Dr. Alfonso Quiroz Cuarón, generalmente nunca se les notificaban sus derechos, obligaciones, correcciones disciplinarias ni los procedimientos de aplicación de las sanciones. Al ingresar, se resguardan sus valores y objetos personales previo registro. La correspondencia que recibe el menor se abre en presencia de una autoridad del Centro, a efecto de comprobar que por ese conducto no se le envíen objetos cuya introducción esté prohibida. ${ }^{17}$

La capacidad de internamiento del centro es de veinticuatro menores. La población generalmente oscila de quince a veinte menores. En cierto sentido es una población pequeña. Ello no significa mejor trato o atención.

El centro ocupa una superficie aproximada de 2 mil 326 metros cuadrados. Consta de tres dormitorios, dos módulos de seguridad, área de gobierno, dos patios con una cancha deportiva cada una, aduana de personas, área de calderas y estacionamiento.

Los tres dormitorios, ${ }^{18}$ conocidos como A, B y C, corresponden a una etapa del tratamiento. Las etapas se denominan fases. La fase I es la más restrictiva en actividades. En las fases II y III, al menor se le conceden derechos y mayor tiempo para que disfruten de ciertos privilegios. Pero dichas fases son flexibles. ${ }^{19}$ Cuando el menor infractor ingresa al centro es ubicado en la fase $\mathrm{I}$, donde permanecen un mínimo de seis meses. Es la fase más restrictiva, ya que realizan escasas actividades. Las actividades son: deportes, aseo personal, pedagogía, trabajo social, psicología, psiquiatría y “aseos programados”, que consisten en realizar la limpieza del pasillo tres veces al día,

\footnotetext{
${ }^{16}$ Reglamento Interno del Centro de Tratamiento para Varones. Expedido en el Diario Oficial de la Federación. Tomo DLXI, núm. 8, lunes 12 de junio de 2000. Art. 54; y "Reglamento Interno del Centro de Atención Especial 'Dr. Alfonso Quiroz Cuarón'”, en Diario Oficial de la Federación. 26 de enero de 2000. Art. 3.

${ }^{17}$ Entrevista realizada el 22 de junio de 2004.

18 “Reglamento Interno del Centro de Atención Especial 'Dr. Alfonso Quiroz Cuarón'”, op. cit. Art. 36. I. Fase uno: Inducción al Proceso de Resocialización. II. Fase dos: Adaptación al Programa y Resocialización III. Fase tres: Integración a la Comunidad.

19 “Recomendación 50/97”, op. cit., p. 106.
} 
después del desayuno, la comida y la cena. En la fase $I$, se realizan las actividades ${ }^{20}$ enlistadas en el cuadro inferior.

A pesar de que estos programas intentan mejorar la adaptación del menor, son contradictorios con las declaraciones de los menores, quienes manifiestan permanecer la mayor parte del tiempo encerrados en sus celdas; incluso desean ser trasladados a un reclusorio de adultos, toda vez que tantas horas de encierro les provoca desesperación. ${ }^{21}$ Las suspensiones de las actividades técnicas son frecuentes, sin siquiera poder ir a las regaderas. El director del centro expresa que a estos muchachos se les suspenden sus actividades porque "mientan la madre", ${ }^{22}$ orinan o arrojan comida al personal.

Para cambiar de fase se requiere la determinación previa del Consejo Técnico Interdisciplinario. Autorizada la fase II, el tratamiento consta: de aseo personal, pedagogía, trabajo social, psicología, deportes, televisión, mecanografía y psiquiatría. En esta fase, según observaciones de la Comisión Nacional de Derechos Humanos, existen irregularidades, ya que hay menores que están en fase I y gozan de la fase II, y viceversa. ${ }^{23}$

En la fase III se proporcionan mayores estímulos a los menores: salen en grupo a hacer deporte;

\begin{tabular}{|c|c|c|}
\hline Actividad & Periodicidad & Duración \\
\hline Deportes & $\begin{array}{l}\text { Dos veces por día } \\
\text { De lunes a sábado }\end{array}$ & 30 minutos \\
\hline Aseo personal & Todos los días & 10 minutos \\
\hline Pedagogía & Lunes a viernes & 1 hora \\
\hline Trabajo social & Lunes a viernes & 1 hora \\
\hline Psicología & Lunes a viernes & 1 hora \\
\hline Psiquiatría & Lunes a viernes & 1 hora \\
\hline Aseo programado & $\begin{array}{l}\text { Una vez por semana, } \\
\text { tres veces al día }\end{array}$ & 30 minutos \\
\hline Televisión & Sábados & 1 hora \\
\hline Recreativas & $\begin{array}{l}\text { Sábados } \\
\text { Domingos }\end{array}$ & $\begin{array}{c}3 \text { a } 4 \text { horas } \\
5 \text { horas }\end{array}$ \\
\hline Visita familiar & Domingos & 4 horas \\
\hline Visita religiosa & Domingos & 1 hora \\
\hline
\end{tabular}

Fase I

\footnotetext{
${ }^{20}$ Ibid., p. 108.

${ }^{21} \mathrm{Ibid}$.

22 Ibid., p. 109.

${ }^{23}$ Ibid., p. 106.
} 
tienen permiso para ver televisión, usar grabadoras y equipos de cómputo; participan en actividades dentro del área de gobierno; tienen clases de ajedrez y pueden ser visitados en horarios extraordinarios.

Al Consejo Técnico del Centro no le está autorizado cambiar al menor de fase (aunque de hecho lo hacen). Para hacerlo debe formularse una solicitud ante el Consejero Unitario, quién, con base en el dictamen del Comité Técnico Interdisciplinario, resolverá lo conducente. Además, el Consejo Técnico del Centro de Atención Especial, puede presentar al Comité Técnico Interdisciplinario un rediseño de las medidas de tratamiento, el otorgamiento de estímulos o la terminación de las medidas. Los criterios para ser ubicado en una nueva fase, incluyen que el menor debe acatar las disposiciones del centro, tener disponibilidad al trabajo, contribuir con las autoridades y el personal profesional; que sean respetuosos, ordenados, limpios; que no muestren conductas inadecuadas o irregulares, y que no falten al respeto a sus compañeros.

Es común en el centro que un menor, de facto, regrese a una fase anterior, acorde con el planteamiento conductista. Incluso, estos cambios sirven para que el menor sea amedrentado por parte del personal, lo que genera miedo y angustia.

Los servicios de psiquiatría, psicología y trabajo social -que deberían ser permanentes- les son retirados si las conductas no son las adecuadas, recluyéndolo a su celda hasta nueva orden del Consejo Técnico. ${ }^{24}$ Como complemento a las fases, y como un derecho los menores, deben ser asignados a un taller para su capacitación conforme a sus aptitudes y edad, otorgándoles el acreditamiento que corresponda en áreas que tengan mayor demanda en el mercado de trabajo.

En un nuevo esquema educativo se hace necesario que los custodios desaparezcan y sean sustituidos por profesores de educación básica, psicólogos, pedagogos, trabajadores sociales, psiquiatras, médicos y otros profesionistas que entiendan y comprendan su actuar, y que, además, vivan dentro de los centros.

Pero un cambio de edificio no es suficiente para hacer más eficiente la adaptación de los menores infractores. Es preciso crear programas específicos de educación en un sistema modular de atención, de acuerdo con las tres variables por las que ingresan los menores: causa, escolaridad y edad.

24 “Recomendación 50/97”, op. cit., p. 110. 


\section{Cómo traer un congreso a casa}

- Lauro Zavala

$\mathrm{E}$ studios recientes indican que el mecanismo más redituable para el avance del conocimiento y el intercambio de información actualizada consiste en la participación de los especialistas (de cualquier campo del conocimiento) en congresos internacionales.

Esta participación puede ser en calidad de ponentes o en calidad de asistentes. En cualquier caso, lo importante -señalan estos estudios, realizados en el Instituto de Matemáticas Aplicadas de la UNAM - es participar en las animadas conversaciones que el investigador -o la investigadorapuede sostener de manera informal con los colegas que trabajan en áreas afines.

Si tomamos en cuenta lo anterior, resulta muy útil organizar congresos internacionales en los países - como México- donde los investigadores no siempre contamos con las mejores condiciones para la investigación.

A continuación señalo, con base en mi experiencia institucional, algunas consideraciones que debe to-mar en cuenta el profesor que decida organizar un congreso internacional en nuestro país.

En primer lugar, es importante recordar que en nuestras universidades todavía no existe alguna oficina encargada exclusivamente de apoyar a los académicos que decidan organizar un congreso para atraer a los más importantes investigadores del mundo en su campo de trabajo.

También hay que recordar que en nuestro país no existen campus acondicionados con dormitorios para la residencia de estudiantes y profesores. Por esta razón, el lugar donde se habrá de realizar el congreso y el lugar donde se habrán de hospedar los participantes suelen estar diseñados para reuniones de negocios o para el hospedaje turístico, pero no para el trabajo académico, el cual requiere condiciones específicas, y cuyo costo, en el extranjero, siempre es menor al de un viaje con fines turísticos o de negocios.

Por ello, a pesar de que la organización de estos encuentros sea una actividad importante, es vista, en la práctica administrativa, como algo excéntrico, costoso y poco trascendente. Sin embargo, exactamente lo contrario es cierto: los beneficios en términos de avance del conocimiento son mayores que el costo en tiempo y recursos financieros que se invierten en la publicación de una revista especializada o en la publicación de libros.

Sin embargo, durante todo el proceso de organización de un congreso, hay que estar al pendiente

- Profesor-Investigador, Universidad Autónoma Metropolitana-Xochimilco 
constancias de participación en el congreso; transporte o contratación de fotocopiadoras, líneas telefónicas y oficinas de prensa);

elaboración de un directorio de participantes, entregado a cada uno de ellos al concluir el congreso (éste es un utilísimo material de trabajo para los mismos participantes, y es el punto de partida para la organización del siguiente congreso);

preparación de una bibliografía especializada y actualizada para ser distribuida entre los participantes (esto último no siempre se realiza, por supuesto, pero puede ser un material útil para los ponentes);

realización de recorridos o actividades especiales para los participantes (desde callejoneadas en zonas turísticas hasta despedida con mariachis y tequila).

En esta labor es muy útil tener acceso al correo electrónico. Resulta excelente para recibir abstracts y enviar toda clase de mensajes y disquetes completos de manera instantánea y personalizada. La institución organizadora paga todos los gastos, y de esta manera es posible enviar y recibir mensajes desde la PC doméstica de los organizadores, utilizando un módem que podría ser proporcionado por el propio departamento.

\section{Las ponencias}

Desde un principio conviene tener espacio y tiempo para organizar mesas de no más de tres o cuatro ponentes cada una. Cuando las mesas tienen más de cinco ponentes, ello resulta demasiado cansado y confuso para todos, sin que haya tiempo para discutir ninguna ponencia.

Al organizar estas mesas de discusión con la suficiente anticipación, se puede programar que se realicen varias de ellas simultáneamente. Así se puede dar cabida a cien o más participantes en el congreso, cada uno de los cuales podrá presentar su trabajo en algún momento de la semana, y discutirlo con los colegas más próximos a su propio campo de estudio. De esta manera, un congreso en el que haya más de cien ponentes, podría tener una duración de una semana.

Normalmente hay que pensar en veinte minutos para la exposición y diez minutos para la discusión de cada ponencia, y nombrar a alguien para que coordine el empleo del tiempo en cada mesa de discusión. Esta extensión significa no aceptar ponencias que excedan las seis cuartillas, pues el tiempo de lectura de una cuartilla lleva casi tres minutos, en promedio, considerando todos los contratiempos que surgen durante las presentaciones simultáneas.

La función de coordinación interna de cada mesa de discusión la pueden cumplir algunos profesores invitados, o bien alguno de los participantes de la misma mesa de discusión. Esta notificación deben hacerla los organizadores mucho antes del inicio del congreso - pues de otra manera suele haber confusiones- y así resulta más fácil hacer frente a los cambios de última hora, que siempre es 
necesario hacer debido a que inevitablemente varios de los participantes, por diversas razones contingentes, en el último minuto deciden no asistir al congreso.

La convocatoria deber señalar la extensión de los abstracts (de ciento cincuenta a doscientas palabras, y que deben ser enviados seis meses antes del congreso); de la segunda versión (alrededor de mil palabras o cuatro cuartillas, para ser distribuida entre los participantes, y que deber ser enviada seis meses antes del congreso), y la posible orientación temática de las ponencias. Esto último puede darle un cariz especial al congreso, el cual puede incluso proponer un tema específico al que todas las ponencias deberán sujetarse.

Por otra parte, deber reservarse en el diseño de las actividades a realizar durante el congreso -además del tiempo dedicado a tomar los tres alimentos- un tiempo especial para las sesiones plenarias, en las que se podrán programar las presentaciones magistrales, o se discutirán asuntos que interesan a todos los participantes.

También es conveniente, de ser posible, elegir un lugar aislado y agradable, de preferencia alejado de las grandes ciudades, como la Ciudad de México, con lo cual todos los participantes se concentran exclusivamente en escuchar y discutir las ponencias. Así, por ejemplo, el Sexto Encuentro Internacional Mijaíl Bajtín se realizó en la Antigua Hacienda de Cocoyoc, en el estado de Morelos.

\section{Difusión}

Hay que pensar en la difusión más conveniente, previa y simultánea al encuentro, lo cual puede incluir el diseño de un cartel, la realización de entrevistas en la radio universitaria, educativa o comercial, el aprovechamiento del espacio disponible en el boletín interno de la universidad o del departamento, y el envío de información oportuna a revistas gremiales de las asociaciones profesionales en las que se inscribe el congreso. Esto último hay que hacerlo con mucha anticipación (alrededor de dos años antes de la realización del congreso) para que la información se publique a tiempo y llegue a los posibles participantes provenientes del extranjero, pues éstos deben programar sus salidas con varios meses de anticipación, generalmente hacia mediados de año. Otros elementos relacionados con la difusión son los siguientes: la conveniencia de solicitar al área de extensión universitaria la programación de conferencias de prensa; la elaboración de boletines de prensa para la fuente especializada; el diseño de un logotipo especial para el congreso, y la impresión de la papelería que se piensa entregar a los participantes (cuaderno de notas, pluma, gafete, separadores); la instalación de una oficina de prensa o una exposición con materiales específicos durante el congreso.

\section{Publicaciones}

El momento de la planeación general es también el más adecuado para programar las fechas críti- 
cas del proceso editorial para las publicaciones que serán presentadas durante el encuentro, y las que se derivarán de él. Estas publicaciones especiales, realizadas con motivo del congreso, pueden incluir algún número monográfico de una revista prestigiosa, dedicado al tema del congreso; la traducción de estudios relevantes para el campo estudiado, y las ponencias del congreso anterior, cuando de trata de congresos realizados con cierta periodicidad.

Entre estas publicaciones es muy útil para los participantes contar al empezar el congreso con una reproducción en fotocopia de los abstracts enviados por los ponentes. Estos materiales sirven a los participantes para tener una idea más precisa del contenido de cada ponencia, y además permite a los participantes regresar a sus centros de trabajo con los materiales bajo el brazo, para estudiarlos y compartirlos en su propio espacio.

También conviene programar la posibilidad de publicar un libro con los materiales presentados durante el encuentro, para lo cual normalmente se requieren de tres a cuatro años de trabajo después del congreso. Una estrategia editorial que puede resultar conveniente es programar esta publicación como coedición con una editorial comercial, pues ello garantiza la distribución del libro fuera de los guetos universitarios.

Después de concluir la organización de un congreso, siempre queda la sensación de que se pudo haber realizado mejor si en las universidades del país existieran espacios diseñados para esta clase de actividades. Pero, al igual que ocurre en muchos otros campos de la actividad profesional -y personal- en nuestro país, también se tiene la sensación de haber realizado algo que en un principio parecía casi imposible.

En el fondo, esa diferencia es la que termina por hacer sentir a los extranjeros que aquí se les trata de manera especial. $\mathrm{Y}$ es cierto. 
$P 1$ 


\section{Reforestar o restaurar para la recuperación ambiental}

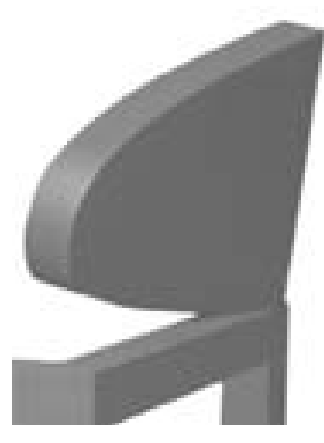

- Óscar Dorado

Dulce María Arias

$\mathrm{U}$ no de los problemas ambientales más graves en México es el de la desforestación, la cual es considerada como la remoción de la cubierta vegetal de un sitio o región. Actualmente, la Organización de Agricultura y Alimentación (FAO, por sus siglas en inglés) estima que en nuestro país se desforestan $631 \mathrm{mil}$ hectáreas por año (1.07\% del total), lo que coloca a México como el quinto país que más superficie vegetal pierde. ${ }^{1}$

En Morelos se ha frenado en gran medida la desforestación, sin embargo, muchos ecosistemas se encuentran fuertemente deteriorados. La deforestación produce consecuencias negativas sobre los ciclos biogeoquímicos e hidrológicos, lo que a su vez provoca una aceleración en la pérdida de nutrientes de los ecosistemas vegetales. Las actividades antropogénicas como la agricultura, la ganadería y los asentamientos humanos son los principales agentes de disturbio. Un disturbio es un evento discreto en el tiempo que elimina o daña a uno o a más individuos, creando espacios abiertos para que los colonicen nuevos organismos. Los disturbios pueden ser pequeños como la caída de un árbol o grandes como incendios forestales de miles de hectáreas. Los incendios son provocados principalmente por prácticas agrícolas tradicionales de apertura y preparación de campos de cultivo conocidas como roza, tumba y quema. Esta técnica consiste en el corte de árboles, arbustos y hierbas, con la subsiguiente quema de ese material. Posteriormente, los campos se abandonan para su regeneración natural. El fuego también se usa para estimular el crecimiento de pastos de los que se alimenta el ganado, por lo que es frecuente que estas actividades se salgan de control, principalmente durante la época de sequía, ocasionando incendios forestales.

Los disturbios originan procesos de dinámica sucesional de las comunidades y generan cambios en su estructura, composición y función, los cuales son conocidos como perturbaciones, que pueden ser medidas por los cambios en riqueza, diversidad y composición de especies que contiene una comunidad.

La pérdida de estos sistemas biológicos lleva consigo, entre otros muchos efectos negativos, la pérdida de la biodiversidad, por lo que su conservación es uno de los temas más importantes en la actualidad, debido a los niveles de destrucción que presentan, pues están rebasando a las grandes

1 J. Agee. Fire ecology of pacific northwest forest. Washinghton, D. C., Island Press, 1993.

- Profesores-Investigadores, Centro de Educación Ambiental e Investigación Sierra de Huautla 
extinciones que se han presentado en la historia de la Tierra. ${ }^{2}$ Del total de la biodiversidad mundial, la mayor parte se concentra en 17 países llamados megadiversos $^{3}$-como México-; sin embargo, estos países (la mayoría tropicales) presentan los problemas más serios de deforestación y fragmentación de ecosistemas.

La biodiversidad proporciona múltiples beneficios a la humanidad: medicinas, hongos, frutos comestibles, forraje, resinas, gomas, aceites, fibras, maderas, entre otros. Además, proporciona un gran número de servicios ambientales, entre los que destacan la purificación del agua y del aire, la regulación de los ciclos hidrológicos y de la temperatura local del aire, la formación y protección de suelo fértil, el control de inundaciones, la protección contra el viento, entre otros. En términos generales, la mayor parte de la población humana desconoce estos beneficios y únicamente lo hace cuando han desaparecido. La falta de una cultura ambiental nos ha impedido valorar la biodiversidad como parte del patrimonio natural que nos ofrece nuestro país.

Los recientes y frecuentes daños que han sufrido los ecosistemas han reducido los beneficios que proporcionaban a la sociedad. Además, nuestro país tiene cada vez menos capacidad para producir recursos naturales renovables y el problema aumenta con la tasa de incremento de la población humana. De este modo, el principal reto para recuperar la sustentabilidad es revertir la tendencia de daño a través de su restauración y rehabilitación ambiental. De ahí la necesidad de tomar medidas efectivas que eviten la desaparición de los ecosistemas y promuevan su conservación, su recuperación y su posible sostenibilidad.

La restauración ecológica tiene como objetivo proporcionar las bases científicas para la reconstrucción y el funcionamiento de los ecosistemas deteriorados y proporcionar sistemas autosostenibles. ${ }^{4}$ Consiste en acciones para la recuperación parcial o total de la estructura y el funcionamiento de los ecosistemas que han sido alterados, generalmente por disturbios producidos por actividades antropogénicas. La restauración dirige un ecosistema a través de acciones encaminadas hacia un ecosistema de referencia, acelerando o saltando etapas de la sucesión. El proceso de sucesión en la comunidad se desarrolla a través de etapas conocidas como serales. Durante el proceso sucesional el suelo evoluciona aumentando su profundidad y complejidad estructural. Asimismo, conforme avanzan las etapas serales no sólo cambia la fisonomía, diversidad y estructura de la vegetación,

\footnotetext{
${ }^{2}$ F. Bazzaz, G. Ceballos, et al. "Ecological Science and the human predicament”, en Science. Vol. 282. 1998, p. 879. ${ }^{3}$ R. Mittermeir. "Primate diversity and the tropical rain forest: case studies from Brazil and Madagascar and the importance of megadiversity countries", en E. Wilson (ed.). Biodiversity. Estados Unidos, National Academic Press, 1988, pp. 145-154.

${ }^{4}$ K. Urbanska, N. Webb y P. Edwards. Restoration ecology and sustainable development. Cambridge, Cambridge University Press, 1997.
} 
sino que también se incrementa la diversidad de la fauna (dispersores de semillas, polinizadores, descomponedores, herbívoros, carnívoros, etcétera) y de otras formas de vida.

En las últimas décadas el método de restauración más empleado ha sido el de reforestación; aunque generalmente carece de un respaldo científico y no tiene como objetivo la recuperación del funcionamiento original del ecosistema. Es por eso que en México se han utilizado incorrectamente especies exóticas, consideradas como especies que están presentes en un sitio pero que no son nativas o propias del lugar (i. e., los eucaliptos y las casuarinas, ambas de origen australiano). Debido a que las especies exóticas no están adaptadas a las condiciones locales, la reforestación tiene poco éxito, pero cuando lo tiene, afecta de manera negativa la diversidad de las especies nativas y las características del suelo. Generalmente, estas especies son utilizadas por su resistencia a plagas, sequía e infertilidad del suelo; además, presentan un crecimiento rápido. Por ejemplo, las especies de Eucalyptus han sido utilizadas de forma constante en programas de reforestación, ya que tienen gran relevancia en la producción de celulosa (aunque en nuestro país no se explote), presentan un crecimiento rápido, se pueden regenerar vegetativamente, tienen pocos requerimientos nutricionales, son altamente competitivas y tienen pocos depredadores. A pesar de esto, no son buenas especies para la restauración ecológica debido a que: producen hojas que se degradan muy lentamente, ocasionando inundaciones y no permitiendo que el agua de lluvia se filtre a los mantos freáticos; las hojas tienen un bajo valor nutritivo; son organismos que liberan sustancias alelopáticas, las cuales inhiben el establecimiento y desarrollo de especies cercanas; el suelo permanece desnudo, lo que favorece su erosión y la pérdida de nutrientes; y alteran el ambiente, haciéndolo inadecuado para que las especies nativas de flora y fauna se desarrollen.

Sin embargo, cada vez es más frecuente encontrar especies nativas dentro de los 480 viveros administrados por instituciones federales, estatales, municipales o comunitarias. Actualmente, en México se utilizan alrededor de 30 millones de árboles para reforestar anualmente una superficie de 200 mil hectáreas.

Para la obtención de resultados satisfactorios en el uso de especies nativas en programas de restauración ecológica es necesario incrementar los esfuerzos en el estudio de la historia natural, ecología, germinación, establecimiento y manejo de las especies disponibles, con la finalidad de mejorar las técnicas de propagación. Además, es importante tomar en cuenta la utilidad que los pobladores de la localidad le dan a las especies propuestas para restaurar; lo anterior, permitirá incrementar el éxito en la conservación de las áreas restauradas.

Es importante que las especies utilizadas en los programas de restauración cumplan las siguientes características: fácil propagación; tolerancia a las limitantes ambientales como la baja fertilidad del suelo, compactación de suelos, sequía, salinidad, 


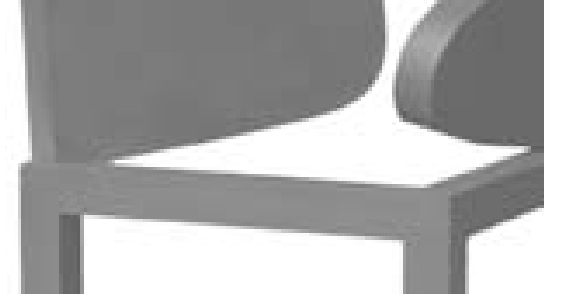

entre otros; rápido crecimiento; alta producción de hojarasca y fácil descomposición de ésta; no tener tendencia a propagación malezoide incontrolable; presentar asociaciones micorrísicas o nódulos fijadores de nitrógeno que compensen el empobrecimiento del suelo (bajos niveles de nitrógeno, fósforo, nutrientes); presentar algún beneficio para la población humana, para que no sean eliminadas; y que tiendan a facilitar el establecimiento de flora y fauna nativa al restablecer el microhábitat y proporcionar alimento. Se espera que con el tiempo la comunidad pueda recuperar de forma natural su estructura y funcionalidad acercándose gradualmente a las condiciones que tenía antes del disturbio.

\section{Restauración ecológica}

Actualmente el Centro de Educación Ambiental e Investigación Sierra de Huautla (Ceamish) de la Universidad Autónoma del Estado de Morelos trabaja en el proyecto “Restauración Ecológica de la Selva Baja Caducifolia (SBC) en el Estado de Morelos”.

La creciente preocupación por conservar la flora y fauna de Morelos, ha llevado a la comunidad científica, a la sociedad y al gobierno a impulsar la formación de Áreas Naturales Protegidas (ANP). Actualmente, se cuenta con nueve ANP, resguardando una superficie de 131,924 hectáreas, equivalente al $26.7 \%$ del territorio estatal, ubicando a Morelos en el cuarto lugar con mayor proporción de superficie protegida.

Debido a la gran importancia que tiene la SBC en Morelos se creó la Reserva de la Biosfera Sierra de Huautla, con un área de 59,030 hectáreas, ubicada en la Cuenca del Río Balsas, constituyendo un rico reservorio de especies endémicas. Cuenta con una topografía accidentada cuyo intervalo altitudinal varía de los 700 a los 2,240 m conteniendo una amplia representatividad de ecosistemas.

La región Sierra de Huautla proporciona recursos hidrológicos de gran valor, y su cubierta forestal protege represas, canales y obras públicas que permiten el florecimiento de las actividades productivas para una amplia región del estado de Morelos, especialmente en los municipios de Amacuzac, Puente de Ixtla, Jojutla, Tlaquiltenango y Tepalcingo. La reserva contiene zonas con diferentes etapas sucesionales debido a disturbios de tipo antropogénico

En los últimos ocho años la UAEM, en particular el Ceamish, ha incrementado esfuerzos por colaborar de una manera más estrecha con el gobierno estatal y con la creación del Programa Estatal de Restauración Ecológica de la Selva Baja Caducifolia y el compromiso de fortalecer las políticas ambientales. Este proyecto tiene como objetivo general establecer estrategias de restauración ecológica que faciliten los procesos de sucesión vegetal de los ecosistemas de la Reserva de la Biosfera. En particular, en una primera fase, se elaboran mapas de distribución geográfica y patrones fenológicos de las especies vegetales; se zonifica y jerarquiza el territorio de acuerdo al grado de deterioro; se determinan las especies vegetales potenciales para ser empleadas en programas de restauración ecológica; y se evalúan las especies vegetales 
que aceleran los procesos de sucesión secundaria. En esta primera etapa se están inventariando las especies vegetales disponibles, resaltando estudios sobre la historia natural de la especie y sus usos potenciales, entre los que destacan: distribución geográfica, determinación taxonómica, usos, historia natural, épocas de floración y fructificación, estadios de desarrollo más susceptibles y tolerancia a suelos pobres.

Además, se cuenta con la Unidad de Restauración Ecológica, ubicada en el Campus Sur de la UAEM, en el municipio de Jojutla, donde se llevan a cabo investigaciones básicas y aplicadas, así como talleres de restauración. Asimismo, cuenta con un grupo heterogéneo de investigadores (especialistas en restauración, ecólogos, taxónomos, etnobotánicos, educadores ambientales, biólogos moleculares, entre otros) que permiten un enriquecimiento en los temas de estudio.

La creciente preocupación por la destrucción de los recursos naturales ha llevado a la sociedad y al gobierno a impulsar alternativas dirigidas a la conservación de los ecosistemas naturales, así como al uso y explotación adecuada de la biodiversidad. La restauración ecológica recientemente es muy aceptada por los éxitos que ha tenido. En Morelos los ecosistemas en estudio presentan diferente grado de perturbación, por lo que, en ellos se debe actuar de acuerdo con objetivos específicos, ya sea para mantener la diversidad, la captación de agua, la fijación de $\mathrm{CO}_{2}$, la generación de oxígeno, o las actividades recreativas. Asimismo, Morelos cuenta con lo necesario para emprender un programa estatal de restauración ecológica utilizando especies nativas, ya que tiene abundantes especies de herbáceas, arbustos y árboles nativos; un conocimiento científico y empírico de la historia natural de muchas especies vegetales; instituciones de investigación; viveros y personal con experiencia en la propagación de especies; un ambiente ampliamente heterogéneo, así como una gran diversidad de especies vegetales.

Es importante impulsar programas de restauración ecológica para favorecer la utilización de especies herbáceas, arbustivas y arbóreas nativas que tengan como característica el establecerse y crecer rápidamente en ambientes con alto grado de disturbio y que, con el tiempo, favorezcan la formación y la fertilidad del suelo, así como la recuperación de los ciclos hidrológicos y de un microclima similar a los de un estado de predisturbio, facilitando la recuperación de al menos alguna parte de la flora y fauna nativa que aún se encuentra en sitios aledaños. Por otro lado, si la reforestación continúa realizándose con especies exóticas, ocasionará paisajes verdes pero desolados, con individuos que inhiben el establecimiento de la gran mayoría de las especies de flora y fauna de la localidad. Además, generalmente se hace con muy pocas especies, lo cual incrementa un empobrecimiento del suelo y una pérdida en la diversidad biológica. 


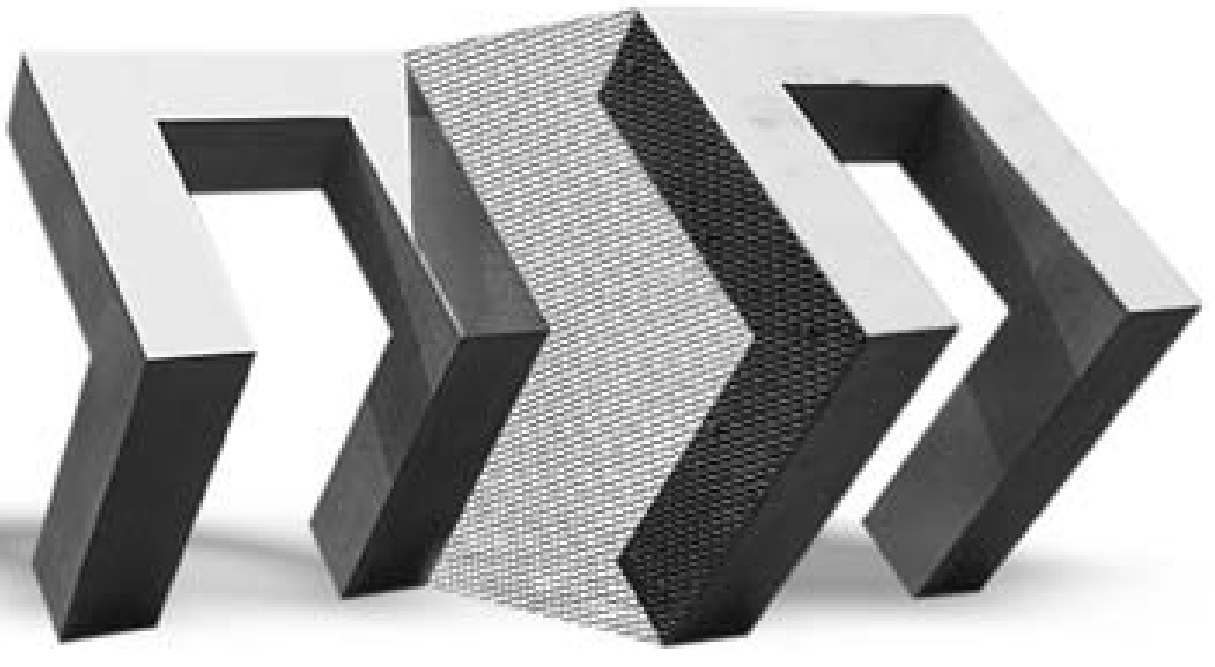

Translado, 1998 


\section{Astrobiología, una nueva disciplina científica}

- Sandra I. Ramírez

Horacio Terrazas
A I encontrarnos bajo un cielo nocturno adornado con millones de estrellas titi-

lantes, pareciera como si el Universo nos mirara desafiante a través de sus estrellas, y éstas, con ojos retadores, invitaran a la especie humana -casi imperativamente- a adentrarse en sus misterios, convertidos en preguntas desde tiempos muy remotos y que gracias a los avances científicos y tecnológicos podemos explorar de una manera más eficaz. Pues bien, la astrobiología ha aceptado ese desafío.

El firmamento que podemos observar en alguna noche oscura y despejada nos provoca la sensación de saber que somos impresionantemente diminutos dentro de un Universo majestuoso, inmenso, quizás interminable. Un segundo pensamiento que nos embarga es el de imaginar los millones de astros posibles con los que compartimos ese Universo, ¡cuántas miles de galaxias, planetas, lunas, estrellas habitando el mismo espacio! Inevitablemente emerge la pregunta: ¿estamos solos en el Universo?

Para decepcionar un poco a los fanáticos hollywoodenses, la astrobiología no tiene como objetivo encontrar hombrecillos verdes tomando el té o ¡bebiendo un refresco de cola en Marte! No, la astrobiología está consciente de que si se descubriera vida extraterrestre, tendría que ser vida microbiana; al menos por ahora.
Es una nueva disciplina científica que investiga la vida en nuestro planeta y fuera de él. Estudia origen, evolución, distribución y destino de la vida en el Universo. Constituye un área de investigación multidisciplinaria, pues es el esfuerzo combinado de muchas áreas: química, biología, astronomía, física, geología, ingeniería, astrofísica, matemáticas, inclusive filosofía.

El término astrobiología se deriva del vocablo exobiología. La idea que se asociaba a este término en los años cincuenta permitía identificar los estudios de búsqueda de vida fuera de la Tierra, por ejemplo en Marte. Los científicos espaciales de la desaparecida URSS fueron quienes propusieron el término. Recordando aquella vieja rivalidad entre el bloque socialista y el bloque capitalista, particularmente en lo relativo a la carrera espacial, era de imaginarse que Estados Unidos no compartiera el término soviético y que ellos acuñaran su propio vocablo. En 1995, Wesley Huntress Jr. convirtió la astrobiología en un programa multidisciplinario de la Agencia Espacial Norteamericana (NASA) centrado en las ciencias espaciales y biológicas. Tres años más tarde, la NASA instituyó el primer centro de investigaciones astrobiológicas, el NASA Astrobiology Institute (NAI), cuyas entidades constitutivas actualmente se encargan de promover, conducir y liderar la investigación en astrobiología y 
la formación de nuevos investigadores. Además de este centro virtual con sede en EU, existen otros especializados en estudios relacionados con la astrobiología en el mundo, destacando el Centro de Astrobiología (CAB) creado por el gobierno español, el Centro Australiano de Astrobiología (ACA) y la Red Europea de Astrobiología (EANAL).

En México, la astrobiología se reconoce como una disciplina de reciente instauración. En 2001 se instituyó la Sociedad Mexicana de Astrobiología (Soma), con sede en la Ciudad Universitaria, en la Ciudad de México, como resultado del esfuerzo compartido de diversos científicos e investigadores que colaboran en aportar respuestas a las interrogantes y objetivos de la astrobiología, desde sus centros de investigación.

\section{El concepto vida}

Paradójicamente, a pesar de sabernos organismos vivos y de interactuar en un ambiente repleto de seres animados, no estamos aún en posibilidades de presentar una definición genérica de vida completamente aceptada por todas las disciplinas científicas que la han adoptado como objeto de estudio. Ya lo comentaba la astrobióloga Leslie Mullen en algún ensayo: “intentar definir vida no es sólo un ejercicio filosófico; debemos comprender qué es lo que separa a las criaturas vivas de la materia sin vida antes de poder proclamar que hemos encontrado vida en cualquier lugar del Universo".

Al intentar definir vida, asociamos ideas como los procesos de respiración, alimentación, reproducción, excreción, etcétera; sin embargo, muchos de los rasgos que consideramos como propios de los seres vivos se encuentran presentes en el mundo inerte. Por ejemplo, sin ser propiamente un organismo, un cristal tiene la facultad de crecer y de multiplicarse; por lo cual es necesario aclarar que existen organismos que consideramos vivos a pesar de que ni siquiera desarrollan procesos de respiración, como el caso de las bacterias anaerobias que ignoran durante toda su vida la presencia de oxígeno. Intentado clarificar este dilema, los biofísicos Claus Emmeche y James Doyne Farmer han propuesto una lista de las características mínimas necesarias presentes en cualquier organismo para poder considerarlo como vivo: autoconservación: capacidad del organismo para asegurar su existencia en el Universo; autorreproducción: capacidad de reproducir organismos semejantes a él mismo; almacenamiento de información: información genética almacenada en el DNA/RNA; respiración-fermentación: metabolismo convertidor de la energía y materia del exterior en energía y compuestos útiles para el organismo; estabilidad: mediante la creación y el control de su propio ambiente interno, todas las criaturas permanecen estables frente a las perturbaciones del medio exterior; control: las distintas partes que integran un organismo contribuyen a la supervivencia del conjunto; evolución: debido a mutaciones en el material hereditario y a la selección natural, el organismo logra alcanzar una adaptación a su medio ambiente; muerte: etapa final de toda criatura viviente.

A lo largo de miles de generaciones, el ser humano ha asociado a la vida con los procesos bioquímicos, incluso con los sistemas vivientes, plantea- 
miento que, según el biólogo Nasif Nahle, ha sido un error crucial: "la vida y los seres vivientes no son lo mismo que la reproducción, la evolución, el orden estructural y el crecimiento. Estas últimas son características de los seres vivientes, no de la vida". Un poco llevados por este planteamiento, pudiéramos explicarnos por qué el ser humano no ha sido capaz de crear a ningún ser vivo a pesar de los experimentos realizados en laboratorio colocando todos los elementos necesarios, incluyendo los factores físicos que se pensaba habían generado a la vida. Según Nasif Nahle, la vida es un estado físico, no el organismo en sí.

\section{Origen de la vida}

Una de las mayores inquietudes de la astrobiología se centra en el estudio de la aparición de la vida en nuestro planeta, pretendiendo comprender los procesos químicos, bioquímicos y evolutivos que dieron origen a lo que hoy denominamos vida. Desde tiempos muy remotos han surgido un sinfín de intentos para explicar el origen de la vida en la Tierra, que van desde aspectos mitológicos y culturales hasta científicos. Según la ciencia, una de las hipótesis mejor aceptadas se basa en un origen endógeno, es decir, que la vida se originó en la Tierra misma.

Tales eran los pensamientos de Alexander Oparin, bioquímico ruso, y de John Sanderson Haldane, genetista británico, quienes en la década de los treinta propusieron un escenario en el cual a partir de compuestos de carbono y nitrógeno relativamente simples se crearon las primera moléculas orgánicas de importancia para la vida; todo esto formado sobre la superficie terrestre en una atmósfera reductora. En 1953, los químicos estadounidenses Stanley Miller y Harold Urey llevaron a cabo un histórico y sorprendente experimento que provocó asombro en el ámbito científico. Inspirado en las ideas de Oparin y Haldane, en un matraz esférico Miller depositó una mezcla de hidrógeno $\left(\mathrm{H}_{2}\right)$, metano $\left(\mathrm{CH}_{4}\right)$ y amoniaco $\left(\mathrm{NH}_{3}\right)$ y vapor de agua $\left(\mathrm{H}_{2} \mathrm{O}\right)$, constituyentes de lo que se creía había sido la atmósfera de la Tierra primitiva. Esta mezcla fue sometida a descargas eléctricas y tras dos semanas de irradiación, el resultado fue realmente sorprendente: Miller comprobó que se lograron formar al menos dos aminoácidos presentes en todos los organismos vivos: la glicina y la alanina, además de algunos otros aminoácidos y compuestos químicos fundamentales para los seres vivos. ${ }^{1}$ A partir de aquel experimento, muchos investigadores han seguido sus pasos, con aportaciones más sofisticadas, partiendo de la misma base experimental, pero obteniendo mayor complejidad en los resultados.

El desarrollo del pensamiento científico en materia del origen de la vida prevaleció guiado por la hipótesis endógena durante algunos años. Sin embargo, conforme las investigaciones avanzaban, comenzaron a surgir también diversos problemas importantes referentes a la teoría de

${ }^{1}$ S. Miller. A Production of Amino acids Under Posible Primitive Earth Conditions, en Science. Núm. 117. Estados Unidos, 1953, pp. 528-529. 


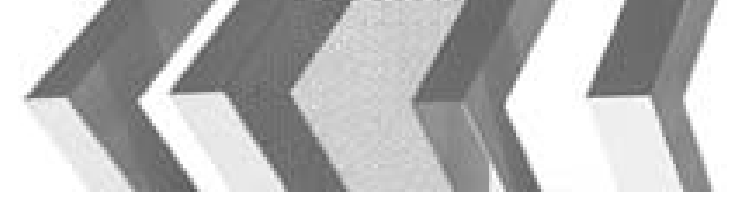

Oparin-Haldane, que evidenciaban que los procesos bióticos no pudieron llevarse a cabo en las condiciones ambientales de la Tierra primitiva propuestas por ellos, además de algunos otros inconvenientes que se iban detectando; dos de los principales fueron:

1) Miller y Urey suponían que la atmósfera terrestre primitiva era altamente reductora, es decir, que existía muy poco oxígeno libre en la misma y que ese ambiente permitía la formación de moléculas orgánicas. Esto se había demostrado fácilmente en el laboratorio mediante los experimentos realizados por Miller. Sin embargo, actualmente se cree que la atmósfera primitiva era medianamente oxidante, o sea, que los elementos carbono (C), nitrógeno $(\mathrm{N})$ y oxígeno $(\mathrm{O})$, no estaban presentes en sus formas más reducidas ricas en hidrógeno sino que el carbono, por ejemplo, estaba presente como monóxido de carbono (CO) y el nitrógeno como nitrógeno molecular $\left(\mathrm{N}_{2}\right)$. Una atmósfera simulada en el laboratorio formada por estos gases, no permitía la formación inmediata de moléculas orgánicas como las que había encontrado Miller en su propuesta experimental;

2) por otro lado, los investigadores se encontraron con la dificultad de que una vez sintetizadas las moléculas biológicamente necesarias para explicar el origen de la vida, algunas de ellas -como lo ácidos nucleicos $\left(\mathrm{ADN}^{2}\right.$ y $\left.\mathrm{ARN}^{3}\right)$ y las proteínas- resultaban ser muy inestables para las condiciones de la Tierra primitiva. La propuesta del biólogo molecular Walter Gilbert ${ }^{4}$ de su mundo primitivo del $A R N$ evidencia con más profundidad esta dificultad. Si el mundo del ARN de Gilbert es cierto, entonces hay que resolver el detalle de la estabilidad de moléculas como ese ácido. Así lo hizo Fred Hoyle, ${ }^{5}$ astrofísico y escritor británico, formulando una hipótesis arriesgada y desconcertante para su época, sugiriendo que la vida pudo haberse originado en el espacio exterior y no aquí, en la Tierra. Según Hoyle, la vida pudo venir del espacio y sustenta su propuesta -conocida como panspermia- en los meteoritos.

Existe evidencia contundente de que en el espacio exterior así como en cometas, meteoritos y polvo interestelar se forman algunas de las moléculas orgánicas indispensables para los seres vivos, que incluyen alcoholes, aminoácidos y carbohidratos. Esto es posible, ya que en el espacio exterior el agua líquida se encuentra en cantidades mínimas - principalmente congelada-, el oxígeno libre $\left(\mathrm{O}_{2}\right)$ existe en cantidades mínimas y por lo tanto se tiene el ambiente reductor ideal para la formación de macromoléculas, y la temperatura oscila entre -260 y $-270{ }^{\circ} \mathrm{C}$, valores extremadamente bajos. Se mencionan a continuación elementos más concretos que apoyan a la propuesta exógena: muchas enzimas necesitan del metal molibdeno (Mo) para

\footnotetext{
2 Ácido desoxirribonucleico.

${ }^{3}$ Ácido ribonucleico.

${ }^{4}$ Walter Gilbert. The RNA World, en Nature. Núm. 319. Estados Unidos, 1986. p. 618.

${ }^{5}$ F. Hoyle y N. C. Wickramasinghe. Astronomical Origins of Life: Steps Towards Panspermia. Estados Unidos, Kluwer Academic Publishers, 2000.
} 
funcionar; el molibdeno es un elemento escaso en la Tierra pero muy abundante en el Universo; el $50 \%$ de la masa de un cometa es agua congelada; la vida requiere de agua para mantenerse; en 1969 cayó en Australia un enorme meteorito que tras ser analizado reveló que contenía grafito (una forma alotrópica del carbono), carburo de silicio (CSi), 74 aminoácidos, casi 250 hidrocarburos diferentes y las cinco bases nitrogenas del ADN, todo formado genuinamente en el espacio; en 1986, cuando la sonda Giotto se encontró con el cometa Halley, se detectaron compuestos como ácido cianhídrico ( $\mathrm{HCN})$, formaldehído $(\mathrm{HCOH})$ y polímeros de estos compuestos; en 1996, científicos de la NASA, al estudiar un meteorito proveniente de Marte que aterrizó en la Antártica hace 13 mil años, encontraron estructuras carbonatadas de forma globular que podrían ser fósiles de bacterias con más de 3 mil 600 millones de años de antigüedad.

Las especulaciones son muchas y variadas. ¿Cómo saber quién tiene la razón? Nunca se sabrá con certeza, pero la ciencia confía en que con base en los resultados de las actuales investigaciones, con sustento en los adelantos tecnológicos y apoyándose en descubrimientos futuros, pueda conformarse una respuesta satisfactoria. El origen de la vida en nuestro planeta no está resuelto, queda mucho trabajo para saber de dónde proviene.

\section{Organismos extremófilos}

El descubrimiento de vida terrestre en sitios y condiciones extremos es cada vez más sorprendente. Al parecer, la vida puede subsistir más allá de los límites pensados como normales por la mayoría de nosotros. Hoy se sabe de la presencia de microorganismos animados que viven bajo condiciones de extremo frío o calor, en ausencia de oxígeno o de luz, en ambientes altamente ácidos o alcalinos; es decir, en lugares inhóspitos antes impensables como adecuados para la vida. A este tipo de organismos capaces de soportar tales condiciones extremas y subsistir exitosamente en ellas, se les ha denominado extremófilos. La presencia de dichos organismos en la Tierra nos invita a pensar que dado que las condiciones y ambientes extraterrestres son considerablemente extremos, cabría esperar que estos extremófilos puedan adaptarse y subsistir en mundos con ambientes análogos a los ambientes terrestres a los que han conseguido adaptarse aquí en nuestro planeta.

El descubrimiento de los organismos extremófilos es de trascendental importancia dentro de la astrobiología, pues se sabe que si se descubriese vida fuera de la Tierra es muy probable que se encontrase algún organismo parecido a ellos, por lo que a nivel experimental se están realizando numeroso proyectos que simulan ambientes espaciales para determinar las posibilidades de vida bajo tales condiciones. Por ejemplo, Fred Hoyle confirma que la especie de bacterias denominada Streptococcus mitis, logró sobrevivir a lo largo de dos años, sometida a condiciones experimentales semejantes a las de la Luna.

\section{En dónde buscar vida}

Con una mejor idea de las posibles formas de vida que se esperaría encontrar en el espacio exterior, el siguiente paso consiste en definir los mejores 


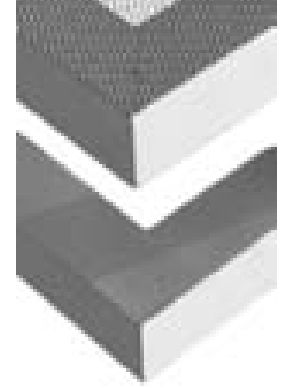

lugares para iniciar la búsqueda, es decir, ¿en dónde esperamos que sea posible encontrar las condiciones adecuadas para la existencia de ese fenómeno indescriptible y a la vez maravilloso que llamamos vida?

La literatura, el cine y la imaginación del ser humano se han encargado de poblar fantásticamente los astros más cercanos y los no tanto de humanoides verdes provistos de inteligencia, con los que nos sería posible comunicarnos. La astrobiología es más pesimista: la exploración del Sistema Solar ha eliminado, uno tras otro, a casi todos los astros que forman parte de él. Algunos de los mejores candidatos como Marte, Titán, Europa o Calisto han comenzado a ser explorados en detalle pero en ninguno de ellos se espera encontrar formas de vida superiores a las microscópicas.

Las condiciones mínimas que un planeta debe presentar o un satélite para poder tener esperanza de encontrar alguna forma de vida en él no están del todo claras. Sin embargo, Carl Sagan especuló acerca de los requerimientos químicos, físicos y biológicos básicos que debería poseer algún posible astro para que la vida pueda ser sustentada en él. Dichas condiciones mínimas son la presencia de agua líquida, de moléculas orgánicas simples y de fuentes de energía suficientes para la vida. La superficie de la Luna, por ejemplo, resulta un medio demasiado hostil. En un mismo día, la temperatura puede variar de $-170{ }^{\circ} \mathrm{C}$ a casi $130{ }^{\circ} \mathrm{C}$. La Luna, además, está desprovista de una atmósfera, gracias a la cual la luz ultravioleta y las partículas cargadas del Sol penetran libremente con toda su intensidad hasta su superficie. ${ }^{6}$

La búsqueda de cuerpos planetarios que pudieran tener las condiciones necesarias que permitan el surgimiento de la vida, está centrada en aquellos que por su temperatura, tamaño, posición relativa a su estrella principal, disponibilidad de agua líquida y de nutrientes o elementos a partir de los cuales se pueda obtener energía, se asemejen a la Tierra. A partir del gran hallazgo -en 1996- de microorganismos fosilizados en el meteorito ALH84001 proveniente de Marte, se piensa que dicho planeta pudo haber albergado vida primitiva millones de años atrás. Recientemente se ha demostrado la presencia de valles en la superficie marciana; dichos valles presentan características similares a los de la Tierra y se sospecha que se formaron como consecuencia de precipitaciones pluviales. Dicho argumento permite especular acerca de la presencia de agua líquida hace más de 3 mil millones de años sobre la superficie de Marte. También se sugiere la presencia de un campo magnético intrínseco ancestral, comparable en fuerza con el de la Tierra. A pesar de la actual superficie fría y seca del planeta rojo, se sabe de la presencia de cristales de hematina -mineral formado a base de sistemas acuosos de altas temperaturas-, lo que implica una evidencia más de que el agua líquida alguna vez estuvo presente en ese planeta. En contraste, Venus, debido a su

${ }^{6}$ A. Rukl. Estrellas y planetas. $2^{a}$ edición. España, Susaeta, 1997. 
efecto invernadero, ha disipado toda esperanza de haber albergado o de albergar vida, pues alcanza temperaturas extremadamente altas, además de que está desprovisto de una capa de aire frío que impida el ascenso de las nubes hasta la estratosfera - a diferencia de la Tierra-, lo que provocaría la evaporación de potenciales océanos de agua en tan sólo unos pocos millones de años.

Actualmente, la tecnología avanza a marchas forzadas trabajando en la búsqueda de planetas habitables fuera de nuestro Sistema Solar. Una de las técnicas usadas consiste en la búsqueda de sistemas planetarios relativamente cercanos a estrellas rojas gigantes, pues en ocasiones estas estrellas presentan un foco demasiado intenso de emisión de radiación milimétrica de la molécula de monóxido de silicio $\left(\mathrm{SiO}_{2}\right)$, que sólo puede explicarse por la presencia de un planeta.

Pero no sólo los planetas son capaces de albergar vida. Datos recientes han permitido saber que los ambientes presentes en ciertas lunas de nuestro Sistema Solar pudieran cumplir con las condiciones mínimas necesarias para ser habitables. Tal es el caso de Titán, el satélite más grande y más misterioso de Saturno, que, se sugiere, posee condiciones geológicas semejantes a las de nuestro planeta en su etapa temprana. Esta luna cuenta con un diámetro de 5 mil 510 km de diámetro, y es el único satélite del Sistema Solar que cuenta con una atmósfera densa, compuesta principalmente de nitrógeno y metano; la temperatura de la superficie de Titán es de aproximadamente $-180^{\circ} \mathrm{C}$. En 1980, la nave Voyager 1 detectó, al sobrevolar el satélite, la presencia de numerosas moléculas orgánicas en su atmósfera, como etano, propano, acetileno y ácido cianhídrico. Después de siete años de viaje, el 14 de enero de 2005, la sonda Huygens entró en la atmósfera de Titán, recabando extensa y muy variada información a lo largo de los 150 minutos que duró su descenso hacia la superficie. La misión resultó todo un éxito, ya que permitió conocer con mayor detalle la composición química, las condiciones ambientales, aspectos del paisaje y mucha más información que científicos se esfuerzan por descifrar. Existe otra luna llamada Europa, un satélite de Júpiter, que representa otro de los focos de atención para los astrobiólogos. Europa presenta un diámetro de $3 \mathrm{mil} 138 \mathrm{~km}$, y una atmósfera muy tenue. La superficie de Europa está cubierta con una capa de hielo, probablemente de 75 a $100 \mathrm{~km}$ de espesor, bajo la cual, se postula, existe un océano subterráneo posiblemente de agua salada que pudiera alcanzar varios kilómetros de profundidad, en donde, se sugiere, pudiera existir la presencia de algún tipo de vida microscópica.

Estas investigaciones han permitido adentrarnos en mayor detalle al conocimiento de algunos de los objetos de nuestro Sistema Solar, pero no debemos olvidar la presencia de otros sistemas planetarios cuyo número es enorme, ya que sólo en nuestra Vía Láctea existen más de 100 mil millones de estrellas. Actualmente, un gran número de científicos e investigadores trabajan en la detección de planetas extrasolares o exoplanetas en el Universo. Hasta ahora, los astrónomos han detectado más de 130 exoplanetas y se espera que en los próximos años la cifra se incremente. La detección de planetas 
extrasolares se logra gracias a la observación minuciosa de las estrellas a través de grandes telescopios, buscando en ellas un ligero movimiento periódico que representaría la presencia de algún planeta que dicha estrella mantuviera en órbita. Las estrellas atraídas por el planeta invisible se acercan y se alejan del astro periódicamente, hecho observable mediante la lectura del movimiento de una estrella.

Los astrónomos tienen la esperanza de captar la luz de un planeta de las dimensiones de la Tierra que gire alrededor de una estrella miles de millones de veces más brillante que nuestro Sol. Para los cazadores de planetas, el reto consiste en bloquear la luz de la estrella para poder ver el planeta. En un sistema planetario detectado lejos del nuestro, los planetas gigantes - como Júpiter- pueden, a una distancia determinada, proteger a los planetas interiores de los residuos espaciales, incluso ayudarlos a seguir trayectorias definidas. Identificar a esos gigantes es un paso en la búsqueda de otras tierras. Estos nuevos planetas no son todavía un lugar para la vida tal y como la conocemos ahora. Los astrónomos están convencidos de que pronto hallarán sistemas planetarios en los que planetas pequeños y templados como la Tierra puedan originarse y donde algún tipo de vida tenga quizá la posibilidad de florecer. Los ingenieros trabajan en tecnologías capaces de registrar el tenue brillo de un planeta junto a la deslumbrante luz de su sol, como es el caso de la futura misión de más de mil millones de dólares denominada Buscador de Planetas Terrestres (TPF), un proyecto conjunto de las agencias espaciales norteamericana y europea que iniciará en 2014 y cuya misión será detectar luz de planetas del tamaño de la Tierra y buscar señales que indiquen su habitabilidad. A su vez, el astrónomo estadounidense William Borucki planea una misión espacial denominada Misión Kepler, la cual consiste en un telescopio espacial que será lanzado en 2007 y buscará detectar un oscurecimiento que indique la presencia de planetas del tamaño de la Tierra. La NASA espera lanzar otra ambiciosa misión en el 2009, la Misión de Interferometría Espacial (SIM), cuyo proyecto se basa en combinar la luz de múltiples telescopios para explorar estrellas y buscar planetas casi tan pequeños como la Tierra.

También existe un programa de búsqueda de inteligencia extraterrestre llamado Search for Extra Terrestrial Intelligence (SETI), centrado en detectar señales electromagnéticas enviadas por formas de vida inteligente y tecnológicamente avanzadas de otros mundos mediante una serie de radiotelescopios distribuidos en la Tierra, destacando entre ellos el ubicado en Arecibo, Puerto Rico, el más grande del mundo. En 1984 se fundó el Instituto SETI en California, EU, que opera bajo la dirección del astrónomo estadounidense Frank Drake. Aunque hasta ahora los proyectos SETI no han encontrado evidencia de civilizaciones extraterrestres, los científicos confían en obtener próximamente resultados favorables. ${ }^{7}$

\footnotetext{
${ }^{7}$ M. Alcubierre. ¿Solos en el Universo?, en ¿Cómo ves? Año 7, núm. 73, México, UNAM, 2004, pp. 10-17.
} 
El destino de la vida en el Universo constituye un tema de gran interés, expectación y hasta controversia en nuestra sociedad. ¿Quién hubiera imaginado hace ochenta años el surgimiento de un área científica exclusivamente dedicada a descubrir nuestros orígenes o vestigios de vida en la Tierra, o, más aún, la posibilidad de que la vida tal como la conocemos ahora pudiera continuar su existencia en algún otro objeto planetario diferente al nuestro?

La astrobiología es una ciencia joven, cuya tarea actual es sentar las bases que permitan un mejor manejo y entendimiento del Universo para su óptimo aprovechamiento en un futuro cercano. No sólo desde el punto de vista del enriquecimiento académico, también para encontrar nuevos materiales originados en el espacio, o acaso para encontrar diferentes fuentes de energía; además, por supuesto, de la posibilidad de encontrar formas de vida no basadas en el ADN o quizá ni siquiera basadas en la química del carbono como la vida terrestre.

Si echamos a volar nuestra imaginación, ¿por qué no pensar que la astrobiología está sentando las bases para que en un futuro no tan lejano, cuando la existencia de vida ya no sea posible en el planeta Tierra, se pueda trasladar o producir vida hacia algún astro del Universo? Imaginemos el impacto que originaría en la sociedad el saber que la Tierra no es el único planeta que alberga vida; el comprender que la vida en el Universo no es una característica exclusiva de nuestro planeta, sino que solamente formamos parte de un Universo animado en donde la Tierra simplemente es un planeta más con condiciones habitables. Desde el punto de vista científico, esto sería un avance gigantesco, pues se abre la posibilidad de estar en contacto con distintas formas de vida; incluso de llegar a tener comunicación con algún tipo de vida similar a la nuestra.

Mientras tanto, la astrobiología avanza a pasos agigantados mediante diversos proyectos e investigaciones que pretenden descubrir de dónde venimos y hacia dónde vamos en este misterioso Universo, así como poder saber si realmente estamos solos en él. Nos ofrece, además, la posibilidad de modificar nuestro concepto de lo que hoy conocemos como vida y probar si este concepto es universal; así como visualizar el destino de la vida terrestre en algún otro cuerpo planetario del Universo.

La próxima vez que te encuentres bajo un oscuro cielo repleto de estrellas, quizá valga la pena que alces la vista al firmamento y te preguntes: ¿estamos solos en el Universo? 


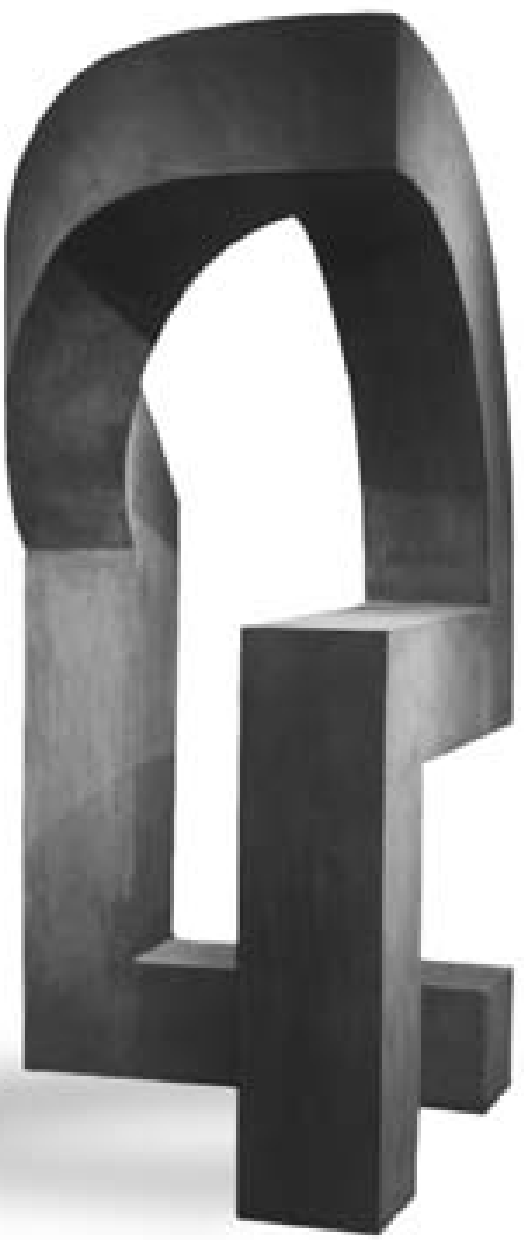

Grom, 1996 


\section{Insecticidas alternativos para el control de plagas en granos almacenados}

- María Idalia Cuevas

$\mathrm{E}$ n el área agropecuaria y más específicamente en el sector agrícola rural aún existe un atraso tecnológico bastante notorio, que, sin embargo, se considera no es debido a la falta de capacidad científica sino a la insuficiencia de recursos económicos para su aprovechamiento. Esta situación se ve reflejada sobremanera en la alta pérdida de los granos almacenados ocasionada por el ataque de plagas insectiles en regiones del país en donde todavía se cultivan básicos para autoconsumo, considerándose mermas de acuerdo con la FAO de entre 10 y $25 \%,{ }^{1}$ pudiendo elevarse hasta 30 y $50 \%$ sobre todo en zonas rurales más alejadas de los focos de desarrollo.

Es evidente que si en estas zonas se emplearan los productos químicos necesarios las pérdidas se reducirían substancialmente, pero, como se considera actualmente, estos beneficios se verían empañados por la contaminación al medio ambiente y al hombre, ya que los productos utilizados hoy día son cada vez más tóxicos, elaborados así dada la habilidad de los insectos de crear resistencia a los mismos. Por esta razón en algunas regiones del planeta han tomando auge los cultivos orgánicos, que tienen como característica el no emplear ningún producto químico tanto en su producción como en su almacenamiento. Es decir, se utilizan, por ejemplo, abonos orgánicos en lugar de fertilizantes químicos. Lo mismo sucede con los insecticidas: para prescindir de ellos se recurre al empleo de diferentes métodos como el control biológico de plagas, la utilización de productos naturales o bioinsecticidas y métodos físicos, entre otros, procurando en todo momento desarrollar un cultivo ecológico.

Modelos de cultivos orgánicos se dan actualmente en Europa, en donde países como Italia han incrementado a 1 millón de hectáreas la superficie destinada a este tipo de cultivos. Frutas, verduras, cereales y aceitunas identificados como orgánicos son cada día más frecuentes en los supermercados de ese país, mientras que más de la mitad de las harinas usadas por los italianos para fabricar pastas son del mismo origen.

Algo similar ocurre en España desde 1991, ya que las áreas especializadas en cultivos orgánicos

1 T.F. Torres. El sistema poscosecha en la alimentación nacional: el sistema poscosecha de granos a nivel rural. problemática y propuestas. Programa Universitario de Alimentos. México, UNAM, 1995, pp. 181-200.

- Profesora-Investigadora, Centro de Investigaciones Biológicas 


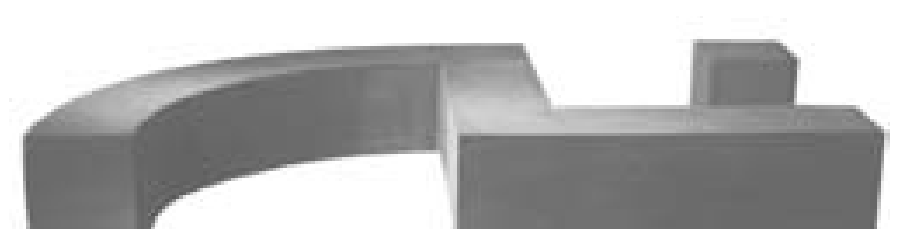

se multiplicaron por 60 y suman en la actualidad unas 270 mil hectáreas sembradas con frutas y verduras, de las que su gran mayoría se exporta a distintos países de la Unión Europea. Por otra parte, en sólo 13 años la superficie destinada a la producción orgánica certificada y apoyada por las autoridades de la Unión Europea se ha multiplicado por 30, pasando de unas 100 mil hectáreas en 1985 a más de 2.8 millones a finales de $1998 ;^{2}$ en tanto que para 2002 en el ámbito mundial la Federación Internacional de Movimientos por la Agricultura Orgánica (IFOAM) reporta una superficie superior a 22 millones de hectáreas, de las cuales el 21.4\% se encuentran en América Latina y de éstas sólo el $0.13 \%$ corresponden a México.

En este ámbito, Argentina y Uruguay son los países latinoamericanos con la más alta proporción de tierras dedicadas a la producción orgánica, convirtiendo al Mercado Común del Sur (Mercosur) en el segundo bloque comercial con la mayor superficie después de la Unión Europea. No obstante, poco a poco nuestro país comienza a despegar en este sentido, en parte influido por el Tratado de Libre Comercio, en el que se exigen normas de sanidad muy estrictas y otro tanto por las cada vez más altas ganancias que produce este tipo de agricultura.
A este respecto, la IFOAM calcula que en 2003 las ganancias obtenidas de productos orgánicos oscilan para el mercado europeo entre 10 y 11 mil millones de euros, seguidos por el Reino Unido, Italia y Francia con más de 1,000 millones de euros. El otro gran mercado es el de Estados Unidos, con ganancias que van de 10 a 11 mil millones de dólares, seguido del de Canadá, con 850 a 1,000 millones de dólares. ${ }^{3}$ Como se aprecia, la agricultura orgánica, incluyendo el almacenamiento de granos, mantiene una tendencia ascendente, nos obliga a preguntarnos por qué si los campesinos que practican la agricultura de subsistencia no cuentan con la asistencia técnica ni con la infraestructura necesaria para ejecutar los controles necesarios para la conservación de sus cosechas, no se les acercan y reavivan los conocimientos tradicionales ya perdidos o distorsionados por el paso del tiempo y se coadyuva a la práctica de cultivares orgánicos.

Por lo expuesto, en el Insectario del Laboratorio de Entomología del CIB se desarrolla una línea de investigación denominada "Búsqueda de productos naturales para el control de insectos plaga de los principales granos almacenados”. La idea de orientar las investigaciones hacia el área de los granos almacenados radica, como se ha señalado,

2 FAO. $22^{\text {a }}$ Conferencia Regional de la FAO para Europa. Inocuidad y Calidad de los Alimentos en la Región con la Agricultura orgánica. Oporto, Portugal, 24-28 de julio de 2000.

${ }^{3}$ E. Gudynas. Producción orgánica en América Latina. Uruguay, Centro Latino Americano de Ecología Social, 2003, pp. 1-6. 
en que éstos representan una parte importante de la dieta del pueblo mexicano, concretamente de aquellos que viven en zonas rurales.

Por esta razón es crucial efectuar una reivindicación de las técnicas ancestrales, estudiarlas detalladamente, complementarlas y tratar en lo posible de adecuarlas e incorporarlas a nuestra agricultura; persiguiendo junto con las técnicas actuales un manejo integral de los granos almacenados -especialmente los de primera necesidad- teniendo como fin desarrollar una agricultura sustentable más acorde con nuestro derredor biológico y social, reduciendo con ello la peligrosa contaminación de nuestros ecosistemas. Lo anterior conllevaría además de una alimentación más sana, una sensible reducción en los costos de producción, sobre todo y particularmente en las zonas rurales más alejadas.

Ejemplos de las técnicas o prácticas tradicionales, algunas de las cuales todavía se llevan a cabo, son la exposición de los granos al sol para la eliminación de diversos tipos de insectos, ya que éstos generalmente no toleran temperaturas superiores a $40{ }^{\circ} \mathrm{C}$. Además, con esta acción se disminuye la humedad excesiva del grano protegiéndolo del ataque de hongos. Otra práctica aplicada por los campesinos de regiones rurales es la de almacenar sobre plataformas elevadas de madera la mazorca del maíz sin desgranar para hacer pasar posteriormente humo a través de ellas, con la finalidad de mantener los granos secos y protegidos contra invasiones de insectos plaga. Otros acostumbran guardar la cosecha sin desprender las hojas del maíz, dado que éstas le dan cierta protección al ataque de insectos debido a que les impiden llegar, posarse, copular, ovipositar y dañar al grano.

Aunado a lo anterior, se reporta que algunos agricultores mezclan arena, ceniza de carbón vegetal y algunos otros materiales con los granos para evitar la reproducción de insectos; al parecer, éstos lesionan por fricción su cutícula haciendo que pierdan humedad y si el grano está completamente seco se deshidraten y mueran. Finalmente, por tradición en muchos lugares del mundo, incluyendo México, los agricultores mezclan plantas locales con el grano que se almacena. La información de qué especies vegetales y qué parte de éstas son las que se combinan con los granos se transmiten verbalmente de generación en generación. Algunas de las plantas utilizadas en estas prácticas son la semilla de chile guajillo (Capsicum sp.), el epazote morado (Chenopodium ambrosoides), el ajo (Allium sativum ) y la ruda (Ruta graveolens), entre muchas otras.

Por la importancia de lo planteado, en el Laboratorio de Entomología del CIB se ha llevado a cabo un sinnúmero de bioensayos en los que se ha experimentado tanto con materiales inertes como con un buen número de plantas (más de 70 en diferentes formulaciones, dosis y con diversas partes de su estructura, para la elaboración de insecticidas botánicos); algunas reportadas con ciertas 
propiedades insecticidas, en tanto que otras seleccionadas por presentar alguna otra característica en particular.

\section{Experimentación}

Por mencionar sólo algunas plantas y materiales inertes evaluados podríamos citar los siguientes. En cuanto a plantas se han probado: huizache (Acacia farnesiana); cebolla (Allium cepa); ajo (Allium sativum); chicalote (Argemone sp.); oreja de liebre (Asclepias glaberrima); lirio acuático (Eichhorrnia crassipes); parota (Enterolobium cyclocarpum); chile guajillo (Capsicum sp.); epazote (Chenopodium ambrosioides); coatecomate (Crescentia alata); colorín (Eritrina americana); noche buena (Euphorbia pulcherrima); albahaca (Ocimum basilicum); piracanto (Piracantha coccinea); guamúchil (Pithecellobium dulce); ruda (Ruta graveolens); mala mujer (Solanum amazonicum); quitamanteca (Solanum sp.); siete dedos (Syngonium podophyllum); pericón (Tagetes lucida); valeriana (Valeriana officinalis); hoja elegante (Xanthosoma robustum); mafafa (Xanthosoma sp.); hierba del sapo (Estilingia celallensis) y tripas de judas (Cuscuta tintorea), entre otras. En lo que respecta a los materiales inertes probados, tenemos tierra de diatomeas, cal, ceniza, carbón vegetal, arena y sal.

Todos estos productos se han evaluado para el control de algunas de las plagas más importantes de los granos almacenados, como el gorgojo pinto del frijol (Zabrotes subfasciatus), el gorgojo del maíz (Sitophilus zeamais) y el gorgojo del garbanzo (Callosobruchus maculatus).

Del cúmulo de información generada se han obtenido resultados altamente prometedores, que pueden ser ya incluidos dentro de un control integral de plagas de granos almacenados. Por ejemplo, para controlar al gorgojo del maíz se ha concluido que la semilla molida de chicalote a dosis de $1 \mathrm{gr}$ de producto por 100 gr de maíz, provoca el $98.9 \%$ de mortalidad y reduce a $0 \%$ las emergencias de nuevas generaciones y el daño al grano. Idénticos resultados se han generado con la raíz molida de valeriana a la misma dosis, en tanto que con hojas y tallos molidos de ruda se ha logrado el $43.3 \%$ de mortalidad y $0 \%$ de emergencias y daño al grano. Resultados un poco menos eficientes han sido obtenidos con la hoja molida del huizache que ocasiona el $33 \%$ de mortalidad, reduciendo las emergencias de nuevas generaciones en 15\% y disminuyendo el daño al grano en $30 \%$. En cuanto a los materiales inertes se ha concluido que la utilización de la cal es un excelente medio para controlar al gorgojo del maíz y al gorgojo pinto del frijol. La dosis ideal para que se ejerza un buen control es también de 1 gr de producto por 100 gr de grano (maíz o frijol).

Con estos resultados nos damos cuenta de que aún existen alternativas de control económicas para los agricultores de zonas rurales o para quienes deseen realizar cultivos ecológicos. Esto es, que tanto el huizache como el chicalote, la valeriana 
y la ruda, son plantas con propiedades insecticidas que pueden disminuir considerablemente algunas de las plagas más importantes de almacén. Las especies señaladas se pueden emplear sin restricción, ya que no causan daño al hombre ni a los animales, a excepción del chicalote, considerada una planta tóxica por lo que tal vez pudiera emplearse únicamente en el tratamiento de semilla destinada a la siembra. No obstante, con esta planta en particular, hace falta realizar más estudios para poder recomendar su empleo.

Por otra parte y aunado a estos excelentes resultados, un elemento más que destaca por su efectividad es la cal, producto de uso bastante común en las antiguas regiones agrícolas pero que desafortunadamente en la actualidad ha sido desplazada por los fumigantes.

Sin embargo, en estos experimentos ha quedado de manifiesto que la cal sigue siendo un elemento imprescindible para el control de plagas de granos almacenados (empleada en dosis y formulación correcta). Lo expuesto muestra sin lugar a dudas la posibilidad de retornar a la agricultura ecológica u orgánica, en donde se emplean medios de control más acordes con el medio ambiente y que repercuten indiscutiblemente en la notoria reducción de los residuos tóxicos.

Finalmente, y como una pequeña aportación de estas investigaciones, se presentan a continuación las etapas que se precisan llevar a cabo para la obtención de los polvos insecticidas y la forma correcta de aplicarlos. En principio, si se decide por utilizar algunas de las plantas mencionadas, es importante realizar los pasos expuestos a continuación.

\section{Preparación y aplicación}

Si se piensa emplear alguna de las plantas recomendadas (o alguna otra) se debe seguir el siguiente procedimiento general:

Secado de las plantas: El almacenamiento de plantas, como es natural, no puede ser indefinido, ya que a través del tiempo éstas comienzan a perder sus principios activos. Por lo tanto, las plantas secas duran en óptimas condiciones seis meses y hasta un año; después, es necesario efectuar un reemplazo por producto nuevo o fresco. Las plantas recién colectadas y libres de impurezas se pueden poner a secar de diversas formas: colgadas en manojos en un cuarto seco y limpio; extendidas entre dos pedazos de tela; guardadas en bolsas de tule o jarcia como las que se usan para ir al mercado, las cuales se cuelgan para que circule el aire libremente entre ellas y no sean atacadas por hongos o insectos. El cuarto de secado debe asearse diariamente evitando colgar plantas cerca de paredes húmedas. Las plantas que presenten aromas fuertes deben secarse separadas de las demás; las hojas y semillas se secan a la sombra; las flores necesitan secarse rápida mente al resguardo de la luz; raíces, cortezas y frutos, deben secarse al sol cortándolos en trozos pequeños; no se deben tocar las hiervas durante 
el proceso de secado y nunca deberá mezclarse el material seco con el fresco.

Almacenamiento: Una vez secas las hierbas, se ponen en frascos de vidrio, madera $u$ hojalata perfectamente secos. Para guardarlas se pueden: rallar: con un utensilio común de cocina; cepillar con garlopa de carpintero para las cortezas o troncos; quebrar con mano o martillo; cortar con un cuchillo; pulverizar con molcajete, mortero o molino de mano (formulación ideal para las plantas recomendadas en esta investigación).

Medidas de prevención: Para reducir al mínimo la posibilidad de que la cosecha se vea infestada por plagas o contaminada por enfermedades en el almacén, es conveniente aplicar algunas medidas de prevención como las siguientes: para ahuyentar insectos plaga y evitar enfermedades es aconsejable asolear el grano por lo menos durante cuatro días. Se recomienda por el hecho de que en muchas ocasiones los granos ya vienen infestados desde el campo; se debe de limpiar perfectamente el grano antes de almacenarlo tratando de eliminar paja, tallos, piedras, etcétera, así como los granos rotos o perforados. Nunca se deberá revolver la cosecha nueva con restos de la anterior; y tener en primer lugar el almacén o el lugar destinado para guardar los granos perfectamente limpio y libre de desechos de la cosecha anterior. Si no se cuenta con almacén o granero es recomendable guardarlos en bolsas de plástico, las cuales se introducirán en costales para evitar que se rompan; o bien, se puede almacenar en tambos con tapa para poderlos cerrar herméticamente teniendo siempre la precaución de colocarlos en un lugar fresco, seco y bien ventilado.

Aplicaciones: La aplicación de los polvos obtenidos de cualquiera de las plantas recomendadas (valeriana, ruda o huizache) se lleva a cabo de la siguiente manera: se mezcla, antes de guardar el grano, cualquiera de las plantas sugeridas a razón de 500 gr de planta molida por cada $50 \mathrm{~kg}$ de grano. Si se desea emplear cal la dosis es la misma. Es importante realizar muestreos periódicos del grano tratado para que, ante cualquier infestación, se vuelvan a realizar las aplicaciones pertinentes. 


\title{
Adolfo Sánchez Vázquez, una veta para la educación valoral
}

\author{
- María Teresa Yurén
}

$\mathrm{E}$

n los últimos años se han realizado diversos esfuerzos por construir la historia de las ideas filosóficas desarrolladas en México en la segunda mitad del siglo XX. A este esfuerzo he pretendido contribuir al hacer un análisis de la obra del filósofo Adolfo Sánchez Vázquez, en el cual he buscado destacar su vigencia y pertinencia. En este artículo examino una veta de la obra de Sánchez Vázquez poco explorada. Me refiero a un conjunto de herramientas conceptuales que o bien pueden utilizarse como instrumentos analíticos o bien pueden emplearse con un sentido praxeológico, es decir, como teoría que puede orientar una praxis y elevar la racionalidad de ésta. Trabajando con este herramental teórico es que he organizado un metamodelo de educación valoral cuyos rasgos centrales presento a continuación.

El documento se estructura en cuatro apartados. En el primero expongo las ventajas que tiene para la educación valoral la posición dialéctica en torno al valor que asume el autor analizado; en el segundo argumento la necesidad de atender en la educación valoral la indisoluble relación entre moral y política; en el tercero aludo a las orientaciones que se desprenden de la obra de Sánchez Vázquez en lo que se refiere a la formación de un talante democrático; finalmente, en el cuarto apartado me refiero al tipo de praxis educativa que se requeriría para favorecer la educación valoral, desde una perspectiva filosófica como la que sostiene este filósofo.

\section{Valores y moral en la perspectiva dialéctica}

Frente al subjetivismo y al objetivismo axiológicos, la perspectiva dialéctica que sostiene Sánchez Vázquez tiene un enorme potencial formativo. Por una parte, porque nos previene de centrar el proceso educativo en las preferencias y actitudes de los sujetos sin tomar en cuenta suficientemente las repercusiones sociales de éstas. Este olvido ha llevado en no pocos casos a aberraciones en la historia, como cuando un pueblo ha cultivado la preferencia de la pureza racial por encima de los derechos de otros pueblos.

Por otra parte, nos previene también de la tentación metafísica de pensar que los valores están inscritos ya en el ser de las cosas y que son necesarios, inmutables y universales. Esta idea nos coloca en la situación de clasificar a las personas en dos posiciones: la de quienes conocen los valores y son dueños de la sabiduría moral y la de quienes no conocen los valores y se mantienen en una especie de maldad no culpable que hay que tolerar (en el sentido de soportar), pero sólo durante el tiempo razonable para sacar del error a las almas perdidas.

- Profesora-Investigadora, Instituto de Ciencias de la Educación 
El enfoque dialéctico de este autor nos coloca en una posición que favorece el pluralismo y la democracia porque considera que el valor surge de la unidad indisoluble del sujeto y el objeto. Esa relación no es ahistórica, por el contrario, siempre es concreta, singular; se da en un tiempo y en un espacio determinados. Refiriéndose al campo del arte, Sánchez Vázquez alude a la situación estética en la que se realiza esa unidad sujeto-objeto. ${ }^{1}$ Con base en esta idea y considerando al valor en general, he denominado situación axiológica a aquella en la que se da la relación y mutua dependencia entre el elemento subjetivo del valor -la preferencia- y el elemento objetivo - una cualidad o propiedad objetiva-. El valor está sustentado en ciertas propiedades reales que no son valiosas por sí mismas, pero que llegan a ser valiosas cuando un sujeto las pone en relación consigo mismo, con sus intereses y necesidades. En palabras de Sánchez Vázquez, "el valor no lo poseen los objetos de por sí, sino que éstos lo adquieren gracias a su relación con el hombre como ser social. Pero los objetos, a su vez, sólo pueden ser valiosos cuando están do-tados efectivamente de ciertas propiedades objetivas". ${ }^{2}$

Una consecuencia que de aquí se deriva es que el valor existe idealmente en la situación axiológica, pero sólo puede existir realmente cuando media la praxis. Es el ser humano - dice Sánchez Vázquez-, como ser histórico social y con su actividad práctica, el que crea los valores y los bienes en que se encarnan, al margen de los cuales sólo existen como proyectos u objetos ideales. ${ }^{3}$

Entre valores y moral hay también una estrecha relación, pues la preferencia y la realización del valor forman parte de la estructura del acto moral. En efecto, según este autor, los elementos que dan estructura al acto moral son: el motivo (aquello que impulsa a actuar o perseguir un fin); la conciencia del fin que se persigue (anticipación ideal del resultado por alcanzar); la elección de un fin entre otros (lo cual implica ponderar los valores de los distintos fines y determinar que uno de ellos es preferible a los demás, es decir, es más valioso que los otros); la decisión de realizarlo (la voluntad de hacer efectivo el acto, asumiendo las consecuencias que tendría el realizarlo), y la realización del acto moral (el empleo de los medios adecuados para hacer el resultado efectivo, con sus respectivas consecuencias). ${ }^{4}$

La moral es algo más que preferencias y realización de valores. En la perspectiva de Sánchez Vázquez, la moral surge cuando el ser humano forma parte de una colectividad. ${ }^{5}$ Consiste en un

\footnotetext{
${ }^{1}$ A. Sánchez Vázquez. Invitación a la estética. México, Grijalbo, 1992, p. 105.

${ }^{2}$ A. Sánchez Vázquez. Ética. 22a ed. México, Grijalbo, 1979, p. 118.

${ }^{3}$ Ibid., p.123.

${ }^{4}$ Ibid., pp. 66-68.

${ }^{5}$ Ibid., p. 33.
} 
conjunto de normas y reglas de acción destinadas a regular las relaciones de los individuos en una comunidad social dada ${ }^{6}$ e implica no sólo el conjunto de principios, valores y prescripciones que se aceptan como válidos (dimensión normativa), sino también los actos concretos que se realizan conforme a esas normas, principios y valores (dimensión fáctica). ${ }^{7}$ Además de estas dimensiones que señala expresamente este autor, podemos inferir otra que hace referencia a la "aceptación libre y consciente de esas normas" ${ }^{8}$ y que podemos llamar dimensión personal.

De esas distinciones se derivan algunos aspectos que es indispensable atender en la educación valoral, cuando se trabaja desde una perspectiva dialéctica. Por una parte, hay que considerar el conjunto de prescripciones y valores o ideas de la vida buena (sintetizadas en el término eticidad) que por la vía de la socialización y la enculturación se trasmiten de una generación a otra; por otra, hay que atender a los procedimientos en virtud de los cuales un sujeto pondera valores y construye principios conforme a los cuales juzga normas y se adhiere o no a ellas. Además, es indispensable estimular el desarrollo de la capacidad práctica del sujeto para realizar los valores que ha considerado preferibles y para actuar conforme a las normas y principios a los que se ha adherido. En suma, una educación valoral de corte dialéctico debe atender a la eticidad que se internaliza y a los procedimientos de juicio moral, 9 pero sobre todo, a la capacidad práxica del agente moral. Esto último es especialmente importante en un momento como el actual en el que, como dice Bauman, los sujetos han perdido capacidad de agencia ${ }^{10}$ por efecto de la lógica instrumental que se impone en todos los órdenes de la vida.

\section{De la actuación moral a la actuación política}

La obra de Sánchez Vázquez permite también superar una posición que no por frecuente en el ámbito de la educación valoral deja de contradecir la función de esta forma de educación. Me refiero al hecho de ignorar que en sociedades en las que se ejercen diversas formas de dominación, explotación y exclusión, las cuestiones morales son también cuestiones políticas en la medida en la que las normas, los principios y valores prevalecientes suelen justificar la dominación o el ejercicio del poder de unos sujetos sobre otros. Este velo que suele desplegarse para ocultar la dominación hace inaceptable lo que, en cambio, resulta deseable

${ }^{6}$ lbid., p. 35.

${ }^{7}$ Ibid., p. 57.

8 Ibid., p. 55.

${ }^{9}$ Estos dos aspectos corresponderían a forjar la personalidad moral en lo que J. Puig denomina identidad sustantiva $e$ identidad procedimental. Cfr. J. Puig. La construcción de la personalidad moral. Barcelona, Paidós, 1992. (Papeles de Pedagogía 30).

${ }^{10}$ Z. Barman. En busca de la política. Tr. M. Rosenberg. $2^{\text {a }}$ ed. México, FCE, 2002, p. 14. 
desde una perspectiva dialéctica: que la actuación moral se traduzca en actuación política para reivindicar derechos individuales y sociales.

El filósofo llama la atención sobre tal ocultamiento ideológico de la dominación y sobre la necesidad de no aceptar sin más las normas morales. Esto conduce necesariamente al criterio pa-ra juzgar dichas normas. Al respecto, no cabe duda de que Sánchez Vázquez valora el principio formal kantiano que exhorta a considerar siempre al ser humano como un fin y no como un medio, hasta el punto de afirmar que un indicador del progreso moral es la conducta de los sujetos que hacen efectivo dicho principio en actos concretos. ${ }^{11}$

Sin embargo, su perspectiva dialéctica le obliga a superar la posición puramente formalista para bus-car un principio material. Éste aparece de manera implícita en toda su obra y podemos denominarlo principio de emancipación. Una posible enunciación de este principio sería: “Tiene validez moral una norma o un principio cuya aplicación en actos concretos favorezca la emancipación de los seres humanos, entendida como la superación de la dominación de unos sobre otros". Este principio se concreta en las normas que aporta nuestro autor para juzgar la validez de las normas morales. Una norma tendrá: 1) justificación social si corresponde efectivamente a necesidades e intereses sociales; 2) justificación práctica si existen condiciones reales para su aplicación; 3) justificación lógica si la norma demuestra coherencia con las demás normas del código moral del que forma parte; 4) justificación científica si su contenido es compatible con los resultados de los conocimientos científicos; y 5) justificación dialéctica si aporta elementos susceptibles de enriquecerse e integrarse en una moral universalmente humana. ${ }^{12}$ En consecuencia, resulta moralmente deficiente una norma que no satisfaga esos criterios en su conjunto, como sucede con las normas que favorecen de alguna manera la dominación o la explotación.

Según Sánchez Vázquez el carácter político de una norma radica en la medida en que favorece el ejercicio del poder de ciertas fuerzas sociales, en tanto que su carácter moral reside en la aceptación consciente y libre de esa norma por parte de los sujetos. La política está imbricada íntimamente con la moral, pues toda política supone cierta moral y toda moral una política. ${ }^{13}$ Tanto una como otra responden a necesidades e intereses sociales: “la moral como peculiar regulación normativa de las relaciones entre los hombres; la política como actividad práctica social, como lucha de clases". ${ }^{14}$ Por eso, desde el punto de vista de un proyecto

\footnotetext{
${ }^{11}$ A. Sánchez Vázquez. Ética, op. cit., p. 47.

${ }^{12}$ Ibid., pp. 206-212.

${ }^{13}$ A. Sánchez Vázquez. "Notas sobre la relación entre moral y política”, en Thesis. Núm. 5, abril 1980. México, UNAM, Facultad de Filosofía y Letras, pp. 17-19.

${ }^{14}$ Ibid., p. 17.
} 
emancipatorio, contribuir a la transformación de un mundo en el que persisten la explotación y la opresión es una opción política y también una exigencia moral.

Así, frente a la posición que sostiene una política sin moral o la que sostiene una moral sin política, nuestro autor plantea una interdependencia entre política y moral. Por una parte, dice, cuando de lo que se trata es de transformar el mundo (finalidad política), la moral está al servicio de la política; pero esto sólo en cuanto al contenido (sistema normativo dictado por el interés de clase), más no en cuanto a la forma (como regulación normativa de las relaciones entre los hombres asumida por ellos consciente, libre y voluntariamente). Si la subordinación llegara a darse en los dos aspectos, la moral se convertiría en sierva de la política ${ }^{15}$ y ésta última perdería su índole emancipatoria.

Decir que una actuación moral tiene un carácter político no quiere decir que se convierta necesariamente en una praxis política. Esta última tiene su especificidad pues consiste en una actividad desarrollada para llevar a cabo la transformación de la sociedad mediante la conquista del poder político. La praxis política implica también la unidad de factores subjetivos (fuerzas sociales con cierto grado de conciencia y organización) y objetivos (nivel de desarrollo histórico social que hace posible la transformación radical), así como la unidad de pensamiento y acción. ${ }^{16}$ Cuando se logra esta unidad y la actividad se enmarca en un proyecto de creación de una sociedad que permita acceder a la verdadera emancipación del ser humano, la política adquiere un carácter revolucionario.

El verdadero revolucionario debe ser un sujeto moral y, como tal, tender a la extinción de toda forma de dominación. Por esta razón no extraña que Sánchez Vázquez retome la tesis marxista que afirma que el mejor Estado es aquél que prepara las condiciones para su propia extinción y, en congruencia con esto, sostenga que la mejor política es la que tiende a su propia negación. Así, la política revolucionaria ha de conducir a la extinción del Estado que se erige como aparato de coerción y dominación y, por tanto, ha de conducir a la desaparición de la política, entendida como lucha por el poder, como relación entre dirigentes y dirigidos. ${ }^{17}$ Desde este punto de vista, la política revolucionaria se subordina a la moral porque su función es la de contribuir a que se cumpla lo que, en opinión de este autor, es el destino futuro y final de la moral: afirmarse frente al derecho y la política.

Lo anterior significa que para lograr una transformación radical de la sociedad no es suficiente sustituir un poder con otro poder, una función represiva con otra función represiva. El proceso

\footnotetext{
${ }^{15} \mathrm{Ibid}$.

${ }^{16} \mathrm{lbid}$.

${ }^{17}$ A. Sánchez Vázquez. Ensayos marxistas sobre historia y política. México, Océano, 1985, pp. 81-92.
} 


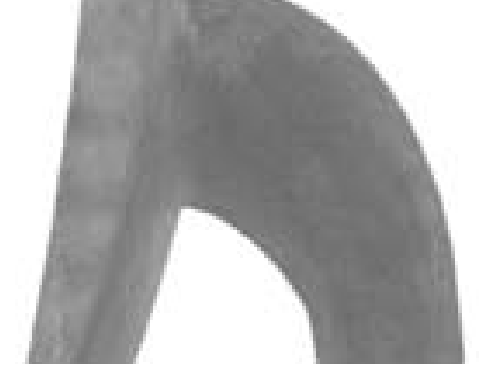

es más complejo y exige que, una vez instaurado un poder revolucionario, éste comience a crear las condiciones de su propia abolición como dominio. Sólo un poder como este, afirma, “abrirá el acceso a eso más allá [del poder como dominación] que consiste en la autodeterminación del individuo y la sociedad y, por tanto, a la verdadera realización de la libertad". ${ }^{18}$ En síntesis, la praxis política es una actividad que, después de abolir al poder como dominación, ha de conquistar el poder propio que es la autodeterminación.

En este aspecto, nuestro autor asume como válidas varias tesis marxistas. En primer lugar, la que sostiene, a diferencia de la posición hegeliana, que el Estado constituye una esfera de enajenación que se opone a la emancipación humana y que el poder político, estatal, no tiene un carácter universal sino particular, de clase. ${ }^{19}$ Asimismo, sostiene la tesis de que lo político se funda en lo social; sin embargo, reconoce que lo político tiene una autonomía relativa dentro del todo social, por lo que, cuando se trata de la conquista del poder, la primacía corresponde a la práctica política.

En torno al problema de la conquista del poder, Sánchez Vázquez atribuye a Gramsci el mérito de haber sentado las bases para una estrategia tendente a superar los dilemas sintetizados en la disyunción reforma o revolución; el acceso al poder es, entonces, fruto de la obtención del consenso social, de la lucha política y de la reforma intelectual y moral que hay que librar antes de alcanzarlo. ${ }^{20}$ Sin embargo, nos previene de que la búsqueda del consenso no debe ignorar la naturaleza del poder político entendido como violencia organizada; hay que considerar que, independientemente de la forma como se ejerza el poder, existe siempre una relación intrínseca entre éste y la violencia. ${ }^{21}$

\section{Responsabilidad,} autodeterminación, democracia

El tránsito del poder como dominación al poder como autodeterminación implica, en el contexto de la obra de Sánchez Vázquez, la dialéctica sujeto-objeto, libertad-necesidad, a partir de la cual el autor se opone tanto a posiciones voluntaristas y subjetivistas, como a aquellas que sostienen el curso de una historia sin sujeto. ${ }^{22} \mathrm{Si}$ bien la situación objetiva engendra los posibles caminos y, en este sentido, condiciona al sujeto, dicha situación no engendra directamente la decisión a favor de una de las opciones posibles. Lo que determina esa opción son factores subjetivos; por ello, los

\footnotetext{
${ }^{18}$ Ibid., p. 124.

${ }^{19}$ A. Sánchez Vázquez. "La cuestión del poder en Marx. Sobre el poder”, en Sistema. Núm. 92, septiembre 1989. Madrid, pp. 4-11.

${ }^{20}$ Ibid., p. 12

${ }^{21}$ Ibid., p. 10-11.

${ }^{22}$ A. Sánchez Vázquez. Ensayos marxistas sobre historia y política, op. cit., pp. 59-64.
} 
agentes históricos no están exentos de responsabilidad moral y política. Esto lo dice Sánchez Vázquez refiriéndose especialmente a los gobernantes y a los dirigentes políticos, ${ }^{23}$ pero puede extenderse a todos los seres humanos que, en tanto agentes históricos, tenemos responsabilidad política y moral.

En efecto, esta responsabilidad es imputable a todos aquellos que ejercen su libertad en el seno de la sociedad, y esto se da cuando el agente político-moral "lejos de excluir la necesidad, supone necesariamente su existencia, y actúa en el marco de ella". ${ }^{24}$ La libertad se manifiesta como capacidad de elección, decisión y acción; capacidad que constituye, a su vez, el presupuesto de la responsabilidad. ${ }^{25}$

Es atendiendo a la dialéctica libertad-necesidad que nuestro autor afirma -siguiendo a Marx- que los seres humanos hacen la historia, en condiciones dadas que los hacen a ellos y en las que ellos la hacen. ${ }^{26}$ Es también en este contexto que el autor insiste en el proyecto histórico de emancipación.

Nuestro autor pone énfasis en la responsabilidad que tenemos los seres humanos como agentes históricos de procurar la verdadera democracia que, entendida a la manera marxista, coincide con la emancipación humana. Esta democracia es unidad de lo universal y lo particular y está orientada a la libertad de todos, por ello es democracia para la mayoría y también para las minorías.

Esta democracia exige romper los límites que le impone la sociedad burguesa que sólo admite la emancipación política y que mantiene al individuo replegado en sí mismo, en su interés privado y en su arbitrariedad privada, y disociado de la comunidad. ${ }^{27} \mathrm{La}$ verdadera democracia constituye un fin en sí e implica la subordinación completa del Estado a la sociedad o, lo que es lo mismo, la pérdida del carácter político del Estado. ${ }^{28} \mathrm{En}$ consecuencia, también implica la desaparición de la burocracia, ese grupo social, jerárquicamente organizado, que se separa de la sociedad para ejercer el poder efectivo en nombre de la clase dominante y que encarna lo que Marx denominó universalidad ilusoria. La desaparición de este cuerpo extraño y parasitario -dice Sánchez Vázquez siguiendo a Marx - se hace necesario para dar paso hacia la autogestión social y al control colectivo de decisiones que es, en suma, el núcleo de la democracia. ${ }^{29}$

${ }^{23}$ Ibid., p. 62-63.

${ }^{24}$ A. Sánchez Vázquez. Ética, op. cit., p. 111.

${ }^{25}$ A. Sánchez Vázquez. Ensayos marxistas sobre historia y política, op. cit., pp. 11-32.

${ }^{26}$ Ibid., p. 56.

${ }^{27}$ A. Sánchez Vázquez. “Marx y la democracia”, en Cuadernos políticos. Núm. 36, 1983. México, pp. 31-39.

${ }^{28}$ Ibid., 36

${ }^{29}$ A. Sánchez Vázquez. "En torno al problema de la burocracia en Hegel y Marx", en Investigación humanística. Núm. 3, otoño 1987. México, UAM, pp. 15-26. 
Desde este punto de vista, no basta la transformación de la estructura económica para superar las enajenaciones. Tampoco basta una democracia formal, representativa, puramente política, cuyo espacio se limita a las casillas electorales y se detiene a las puertas de las fábricas, dice Sánchez Vázquez recordando a Bobbio. ${ }^{30} \mathrm{El}$ valor de la democracia radica en que la participación consciente, racional, en la toma de decisiones que afectan a la comunidad, responde a una exigencia de libertad.

Por esa razón, existe la necesidad de extender y profundizar la democracia. Por extender la democracia, Sánchez Vázquez entiende practicarla en todos los espacios en los que se actúa con otros, como puede ser el ámbito laboral, la familia, la escuela, el grupo de amigos, entre otros. Con la expresión profundizar la democracia se refiere al hecho de mejorar cualitativamente las interacciones de manera que se favorezca la participación de todos los sujetos involucrados y el debate sobre los asuntos que les atañen. Extender y profundizar la democracia significa entonces superar los límites que impone el sistema social; es en este sentido que nuestro autor afirma que la democracia tiene un potencial subversivo. ${ }^{31}$

No se trata, entonces, de una simple negación de la democracia formal (política o parlamentaria), sino de avanzar - sin abandonarla - hacia una democracia real, económica y social. Tampoco se trata de elegir entre democracia representativa o democracia directa, sino de enriquecer la democracia en sus dos vertientes. Se trata, en fin, de ampliar los sujetos, los lugares, las formas y los objetos de participación, todo lo cual supone respeto a los demás, tolerancia, solidaridad y presencia de lo colectivo en la toma de decisiones. ${ }^{32}$ La formación del talante democrático al que aluden los escritos de Sánchez Vázquez constituye un reto para la educación valoral.

De la lectura de los diversos trabajos de su autoría se desprende que el verdadero socialismo cultiva la verdadera democracia y, recíprocamente, la verdadera democracia consiste propiamente en la construcción del verdadero socialismo. Este último, asevera, constituye el terreno apropiado para pasar de los buenos deseos a la encarnación efectiva de las reivindicaciones de libertad, igualdad, justicia y democracia. ${ }^{33}$

Por eso, el sujeto plural del cambio a una sociedad verdaderamente democrática, como la socialista, sólo puede serlo si él mismo practica la democracia en sus relaciones externas e internas; si la democracia no se limita a su forma política sino que se extiende a toda la vida social.

\footnotetext{
${ }^{30}$ A. Sánchez Vázquez. "Democracia, revolución y socialismo”, en Socialismo, Núm. 3-4, oct.-dic. 1989, pp. 13-24.

${ }^{31}$ Ibid., 14-15.

${ }^{32}$ Ibid., 16-19.

${ }^{33}$ A. Sánchez Vázquez. "Después del derrumbe: estar o no a la izquierda”, en Sistema. Núm. 108. Madrid, pp. 57-67.
} 
Según Sánchez Vázquez, la democracia es un régimen de convivencia y un método para adoptar decisiones colectivas; por eso la extensión y la profundización de la democracia deben traducirse en un proceso ininterrumpido de participación cada vez más rico y diverso. ${ }^{34}$ Esto último parece ser la clave de la formación del talante democrático pues sólo participando en las decisiones colectivas el sujeto se vuelve tolerante, aprende las ventajas de la pluralidad, se instruye en el respeto a los otros, aun cuando existan disensos, y tiene la vivencia de la solidaridad.

\section{La praxis educativa}

Un último aspecto que conviene destacar en relación con la educación valoral es la forma que tendría que adquirir la tarea del educador para contribuir a la formación del realizador de valores y del talante democrático. Sin duda alguna, dicha tarea involucra una forma de praxis cuando se realiza cabalmente. Según Sánchez Vázquez, la praxis tiene lugar "cuando los actos dirigidos a un objeto para transformarlo se inician con un resultado ideal, o fin, y terminan con un resultado o producto efectivos, reales". ${ }^{35}$ La verdadera educación responde, sin duda, a esta definición. Además, dice nuestro autor, la praxis es expresión de la dialéctica sujetoobjeto porque de la misma manera que la actividad teórica no es de por sí praxis, tampoco lo es una actividad material del individuo, aunque pueda desembocar en la producción de un objeto, si en ella falta el momento subjetivo, teórico, representado por el lado consciente de esa actividad.

La educación valoral es una praxis en el sentido antes apuntado pues implica la unidad de los momentos subjetivo y objetivo para contribuir a la transformación de un objeto. En este punto cabe afirmar que es el educando quien se transforma a sí mismo mediante su actividad, pero ésta es propiciada y favorecida por la praxis educativa. Por ello puede decirse que la praxis educativa es una praxis que desencadena praxis. Es también una actividad que contribuye a lo que Sánchez Vázquez denomina praxis total que no es otra cosa que el proceso de autocreación del ser humano mismo; proceso que tiene lugar cuando, gracias a su praxis, el ser humano humaniza el mundo y se humaniza a sí mismo. ${ }^{36}$

La praxis educativa está emparentada con la praxis social pero es distinta a ella. Ciertamente, la praxis social es aquella en la que el ser humano es al mismo tiempo sujeto y objeto de ella, es decir, es "praxis en la que [el sujeto] actúa sobre sí mismo [...] Dentro de ella caen los diversos actos encaminados a su transformación como ser social y, por ello, a cambiar sus relaciones económicas, políticas y sociales". 37

Como la praxis social, en la praxis educativa el ser humano es al mismo tiempo sujeto y objeto de

\footnotetext{
${ }^{34} \mathrm{~A}$. Sánchez Vázquez. "La cuestión del poder en Marx. Sobre el poder", op. cit.

${ }^{35}$ A. Sánchez Vázquez. Filosofía de la Praxis. $3^{\text {a }}$ ed. México, Grijalbo, 1980, p. 246.

${ }^{36}$ Ibid., p. 260

37 Ibid., p. 259.
} 
ella, pero a diferencia de la praxis social, la praxis educativa no busca de manera inmediata modificar las relaciones económicas, políticas y sociales, sino que busca contribuir a la transformación del ser humano. El educador, además de actuar con la conciencia de los fines y el conocimiento de los medios para lograrlos, utiliza instrumentos y recursos, y prepara las condiciones objetivas para que el educando tenga experiencias formativas. Al hacerlo, no sólo favorece la formación del educando, sino que, a la vez, él mismo se transforma. La educación no es un proceso en el que lo subjetivo (que se concreta en el proyecto del docente) simplemente se inserta en lo objetivo (la actividad que realiza el docente), sino que se trata de un movimiento que estimula la praxis formativa de los educandos, considerando las condiciones contextuales específicas de cada uno de ellos.

Por lo anterior, la creatividad y la autocrítica son rasgos que caracterizan a la tarea educativa entendida como praxis. Lo que opera en sentido contrario a esa praxis creativa es la reiteración o la burocratización de la práctica. Tanto en un caso como en otro, afirma Sánchez Vázquez, hay una ruptura de la unidad de lo subjetivo y lo objetivo. En el caso de la reiteración, el proyecto se concibe como preexistente a la práctica, como si fuese una entidad platónica inmutable y refractaria a la crítica: la práctica sólo trata de ajustarse a ese proyecto. En el caso de la burocratización de la práctica, el proyecto deja de alimentar a la actividad y ésta se realiza de manera semejante a un proceso mecánico. La praxis educativa, en cambio, requiere permanente innovación no sólo en la actividad, sino también en el proyecto, pues cada educando es una totalidad que merece ser considerada -como decía Kant-como fin en sí mismo. ${ }^{38}$

En suma, aplicada a la educación valoral, la filosofía de Sánchez Vázquez orienta una forma de praxis educativa que contribuye a la construcción del talante democrático que se requiere para enfrentar no sólo el poder político estatal propio del mundo moderno, sino las formas sutiles, ambiguas y subrepticias en las que se ejerce el poder en un mundo que lleva la imprompta del globalismo.

${ }^{38}$ Ibid., pp. 312-316. 


\title{
Crítica o creatividad
}

\author{
- Silvia Kiczkovsky
}

$\mathrm{L}$ as ideas que a continuación se desgranan surgieron ante una invitación para llevar a cabo una reflexión sobre la lectura crítica. La lectura es uno de los temas dentro de los cuales desarrollo parte de mi trabajo de investigación en el ámbito de lenguaje y educación. Sin embargo, nunca había trabajado específicamente sobre lectura crítica y el tema despertó mi curiosidad. Recurrí entonces a la internet para buscar información al respecto. Encontré allí la siguiente definición propuesta por Daniel Kurland: "La lectura crítica es una técnica que permite descubrir ideas e información dentro de un texto escrito". Esta definición se complementa con la de pensamiento crítico que se enuncia de la siguiente manera: “El Pensamiento crítico es una técnica para evaluar la información y para decidir qué aceptar y creer". No pude dejar de sentir cierto asombro por esa concepción, tanto de la lectura como del pensamiento crítico, como meras técnicas utilizadas para descubrir y evaluar algo que hay adentro del texto. No quiero concluir que éstas sean las únicas concepciones que existen en torno a estos conceptos. En realidad, más bien me sirven como excusa para introducir el problema, porque pensé entonces que me interesaba más hablar de una lectura o de un pensamiento creativos que de una lectura o un pensamiento críticos y en los párrafos que siguen intentaré explicar por qué.

El lingüista Michael Reddy ${ }^{1}$ ha descrito de manera muy precisa la metáfora del canal desde la cual podemos interpretar las definiciones anteriores. Reddy y otros autores dentro de la lingüística cognitiva plantean que las expresiones lingüísticas nos permiten rastrear los sistemas conceptuales que estructuran nuestra experiencia del mundo. Gran parte de estos sistemas conceptuales son de naturaleza metafórica y mediante estas metáforas vivimos; esto es, no sólo pensamos y concebimos fenómenos, sino que también, actuamos. Reddy rastreó más de cuatrocientas expresiones en inglés (no hay mucha diferencia con el español) y llegó a la conclusión de que, al menos en lo que hace a nuestro sentido común, hemos entendido el significado a la manera de un objeto que es introducido en un contenedor que son las palabras o los párrafos o los textos. Estos objetos que son introducidos en las palabras por alguien que codifica,

1 En M. Reddy. "The Conduit Metaphor-A Case of Frame Conflict in our Language about Language", en A. Ortony (comp.). Metaphor and Thought. Cambridge, Cambridge University Press, 1979, pp. 284-324.

- Profesora-Investigadora, Instituto de Ciencias Sociales y Humanidades-Benemérita Universidad Autónoma de Puebla 
son enviados a través del espacio, por medio de un canal, hacia un receptor que los recibe y desempaqueta, o decodifica los mensajes, sacando los significados de las palabras, párrafos, textos. No hay espacio suficiente aquí para dar ejemplos de todas las expresiones analizadas por Reddy, pero nos basta con regresar a la definición de lectura crítica que di en un inicio: es una técnica que permite descubrir ideas e información dentro de un texto escrito. Como podemos ver, las ideas reificadas tienen una existencia propia y están en el interior de un contenedor que en este caso es el texto. Esta concepción de la comunicación y del lenguaje, nos lleva a una concepción de la lectura que está implícita en la definición presentada. Esto es, dentro de un texto hay cierta información que alguien ha puesto allí y que yo debo descubrir y sacar, en un proceso uno-uno. En función de esto, una vez que he sacado la información, el pensamiento crítico me permite evaluarla y decidir qué creo y qué acepto desde mis propios sistemas de valores y creencias.

A esta metáfora del canal, Reddy contrapone una nueva metáfora creada por él: la metáfora de los toolmakers o constructores de herramientas, desde la cual piensa otra manera de concebir el proceso comunicativo. Y la concibe por medio de una imagen que es una rueda tabicada en cuatro partes. Dentro de cada uno de los espacios creados existe un individuo: A, B, C y D. A su vez, cada uno de ellos sabe de la existencia de los otros pero no puede conocer las características de sus espacios correspondientes porque el tabique no se lo permite.
Viven en una especie de clausura. La única forma de comunicarse entre ellos es a través de un círculo en el interior de la rueda en el cual pueden depositar un mensaje a la manera de una señal. El hábitat de cada individuo es diferente $y$, por lo tanto, sus necesidades también. Un día, A crea una herramienta que puede utilizar en su medio y ante la alegría de la creación de un nuevo instrumento decide comunicarlo a sus vecinos. Cada uno de ellos recibe el mensaje: tal vez un dibujo, de un rastrillo. $Y$ así inician una tarea de interpretación que los lleva a construir una nueva herramienta que se adapta a las necesidades propias de su hábitat, sin saber a ciencia cierta si en realidad coincide o no con la original creada por $\mathrm{A}$, quien en un primer momento se sorprende ante el cambio que producen en sus propias herramientas, pero finalmente termina por entender que es bueno para el funcionamiento de cada quien y, de este modo, se abre un proceso de comunicación creativa que da por resultado instrumentos siempre nuevos. Desde este punto de vista, la comunicación implica una serie de inferencias en un proceso donde se produce continuamente un esfuerzo creativo. El lenguaje en este caso no está reificado, no asume una existencia propia, como si tuviera el mismo tipo de realidad externa de los objetos, sino que se concibe más bien a la manera de señales que son interpretadas de acuerdo con las necesidades propias del individuo y sus circunstancias, dando lugar a algo nuevo. Esta perspectiva cognitiva coincide más con la tradición interpretativa de origen hermenéutico que con la idea de sacar ideas de un texto. 
La mención de la hermenéutica nos permite pegar un salto hacia otra tradición, para seguir reflexionando sobre el proceso creativo. Los talmudistas judíos, especialistas en el Libro -porque la cultura judía es la cultura del Libro- por medio de una de sus reglas interpretativas que es la guematría, que relaciona letras y números, leen en un pasaje que define al Libro, que el Libro es una boca, y esto implica decir que existe un relación íntima entre lo escrito y la boca. El libro es Libro si es el origen de la apertura de la boca, si es creador o generador de palabra. La palabra sólo habla si es creadora de sentido. Por lo tanto, la interpretación no puede ser repetición. Los talmudistas y cabalistas son los encargados de hacer que la Tradición perdure. Sin embargo, consideran que la Tradición no es un mero acto de recepción y transmisión, sino de (re)creación del sentido. Esa recreación, dice Marc-Alain Ouaknin, ${ }^{2}$ refiriéndose a Franz Resenzweig, es Revelación. Y la Revelación no está en la recepción de la palabra revelada, sino en su renovación, que es también Liberación porque saca al ser de su estancamiento en la obviedad.

Walter Benjamin, ${ }^{3}$ quien teorizaba sobre la historia tomando ciertas bases de la Tradición judía, proponía un concepto de historia que concibiera al tiempo como la yuxtaposición de instantes únicos y no como una continuidad lineal donde se establecen relaciones de causa y consecuencia. Esta imagen le permitía hablar de destellos, relámpagos, que podían producir un cambio que no era el resultado de un proceso, sino de un salto en el presente, en el momento en que se vive. Esos relámpagos traen consigo la idea de la Redención. Benjamin dice que para que el pasado siga vivo, la memoria colectiva debe reinventarlo a cada instante; “...para que el futuro no aparezca como una mera proyección hacia adelante de las tendencias del pasado, hay que presentir su novedad radical a través de los armónicos utópicos codificados en la constelación del presente". ${ }^{4}$ Benjamin sabía tomar imágenes muy sugestivas para crear nuevos significados. $Y$ en este sentido, coincide con los talmudistas en la idea de renovación continua del sentido porque de la ruptura temporal nace lo nuevo.

Si pudiéramos establecer una analogía entre historia y discurso, basada en las imágenes del tiempo y el discurso como línea, o como yuxtaposición, entonces sería posible concebir el sentido como la yuxtaposición de instantes únicos, y la lectura puede presentar destellos que no tienen que ver con la linealidad de la causa-consecuencia, sino con lo multidimensional, que emerge en el presente de la lectura en un contexto y en un yo momentáneo que nos evocan algo único y que puede transformarse en un nuevo sentido, en un nuevo mundo de significados, resultado

\footnotetext{
2 En M. A. Ouaknin. El libro quemado. Filosofía del Talmud. Barcelona, Ríopiedras, 1999.

${ }^{3}$ En Stephane Mosès. El ángel de la historia. Rosenzweig, Benjamin, Sholem. Madrid, Cátedra, 1997.

${ }^{4}$ Ibid., p. 85.
} 
de una actitud frente al sentido, una actitud de creatividad.

Los cabalistas atribuyen mucha importancia a la primera enseñanza de la Torá: si el texto del Génesis comienza con el relato de la creación, el hombre debe ocuparse de la Creación y de su renovación. De esta manera, la realidad es concebida como proceso, el foco no está puesto en el ser sino en el devenir; además, cada instante nos permite hacer emerger un mundo nuevo, en la medida en que lo concibamos como único y podamos romper el tiempo de la linealidad. Y si equiparáramos la Revelación con la Redención, entonces la creatividad nos salva.

Curiosamente, transitando hacia otro extremo, de la religión a la ciencia, David Bohm, físico que trabaja dentro del campo de los quanta propone algo similar. En su libro Ciencia, orden y creatividad, ${ }^{5}$ Bohm filosofa dialogando con su colega David Peat en torno a la encrucijada en que se encuentra en este momento la humanidad. La idea central es que cada vez más concebimos y estudiamos la realidad de manera fragmentaria, de modo tal que al profundizar en un aspecto de ella, dejamos de lado todo aquello que la rodea y esto tiene consecuencias negativas en nuestro vivir. Ejemplo de ello es la distancia entre la economía, la política y la sociedad, lo que hace a la naturaleza y al ser humano. La ciencia está involucrada en este tipo de pensamiento fragmentado y la propuesta de Bohm es la necesidad de un cambio tanto en la ciencia como en la cultura y en la sociedad. Este cambio - afirma- se basa en la creatividad. Sin entrar en detalles sobre su teoría del orden implicado y la creatividad, es interesante notar que al hablar de creatividad introduce la noción de metáfora, que bien podríamos equiparar a la desarrollada por aquellos que trabajan en ciencias cognitivas y la conciben como mecanismo constructor de conocimiento. ${ }^{6}$ Esto es, tanto desde el punto de vista perceptual, como conceptual, se trata de establecer una nueva relación entre dos entidades o entre dos dominios, sobre la base de las semejanzas y diferencias que encontramos entre ellos. En realidad, todo el tiempo estamos estableciendo semejanzas y diferencias, pero desde estructuras ya conocidas, rígidas. La mente percibe aquello que está acostumbrada a ver desde sus hábitos de pensamiento mecánicos. Pareciera que hay un filtro conformado por los sistemas conceptuales que ya han organizado nuestra experiencia del mundo en los diversos dominios en los cuales nos movemos y esto crea la ilusión de estructuras fijas de orden en la realidad. Desde esas estructuras pensamos y actuamos en todos los ámbitos de actividades en los cuales nos desenvolvemos. Esto crea bloqueos en la creatividad. Es en el acto del juego libre del pensamiento donde surgen las nuevas

\footnotetext{
${ }^{5}$ En D. Bohm y F. Peat. Ciencia, orden y creatividad. Barcelona, Kairós, 1988.

${ }^{6}$ En G. Lakoff. "The contemporary Theory of Metaphor", en Metaphor and Thought. Cambridge, Cambridge University Press, 1993, pp. 202-250.
} 
ideas que pueden ser luego sometidas a exploración - propone Bohm-y que rompen con los condicionantes impuestos por las estructuras rígidas de pensamiento.

La manera más adecuada de restablecer los procesos creativos, potencial natural del ser humano que se va perdiendo a medida que crece $y$ se ve sometido a las estructuras convencionales y rígidas, es el diálogo libre, concepto muy distinto al de discusión. La discusión generalmente se conceptualiza y transcurre a la manera de una guerra, recordando a Lakoff y Johnson en Metáforas de la vida cotidiana. Por el contrario, podríamos concebir al diálogo como un libre juego de significados entre la gente que se comunica, muy a la manera de la metáfora de los toolmakers que mencionamos anteriormente. Para Bohm es necesario que los que comunican establezcan una suspensión de juicio, que permita una atención plena a los significados puestos en juego. Esta suspensión de juicio implica la suspensión de las estructuras de pensamiento o sistemas conceptuales, tanto individuales como culturales, lo que libera a la mente y le permite moverse en formas nuevas, siendo capaz de responder a nuevas percepciones creativas superando los puntos de vista que se han mantenido en suspensión. Esto crea un instante único, donde el tiempo se rompe, y emerge una nueva dimensión de significados, esto es, un mundo nuevo. Sería maravilloso vivir de instante en instante, nos salvaríamos del aburrimiento y de los lugares comunes. Y no es imposible lograrlo; depende de poder adoptar una actitud que emerja de una manera nueva de concebir el vivir. Pero si no podemos hacerlo de manera continua, al menos podríamos permitir que estos nuevos mundos surjan en los momentos de crisis en los cuales vemos sacudidas nuestra cotidianeidad y las estructuras de pensamiento mediante las cuales vivimos.

He hecho un muy breve recorrido por tres ámbitos muy diferentes desde los cuales se reflexiona sobre la creatividad y los nuevos sentidos que dan lugar a mundos nuevos. He transitado por la lingüística cognitiva, por la filosofía del Talmud y por las ideas de Bohm enunciadas desde un reflexionar sobre la ciencia y la vida cotidiana a través de la física y los sistemas complejos. Por momentos he pensado esta combinación como descabellada y, sin embargo, un impulso en mí me ha movido a hacerla. ¿Será por una necesidad de integrar los mundos fragmentados creando así un universo más amplio donde los diversos ámbitos del vivir no estén reñidos sino integrados? ¿Por qué cada uno de estos ámbitos produce en mí resonancias que me llevan a encontrar analogías, imágenes, puntos de contacto?

La palabra crítica me evoca un mundo de contrarios, de opuestos; un juicio emitido por alguien sobre algo desde una postura diferente. Son dos sistemas de pensamiento en pugna, una lucha desde dos extremos. La palabra creatividad, por el contrario, me permite romper la oposición y encontrar una vía media en la emergencia de mundos nuevos mediante la integración. Si los toolmakers emitieran juicios sobre las herramientas que cada uno de ellos construye, desde las necesidades propias de cada quien, entonces no podrían 
inventar herramientas nuevas. Si los talmudistas y cabalistas leyeran y releyeran el Libro siempre de manera igual para conservar una tradición fundada siempre en los mismos significados perpetuados ad infinitum, el Libro no serviría para pensar el mundo y los seres humanos a lo largo de tanto tiempo. Si no surgieran imágenes o metáforas nuevas en la ciencia, no se abriría el espacio para nuevos paradigmas, para nuevos modelos; es decir, no habría revelaciones, destellos, relámpagos, como los que imaginaba Benjamin en la posibilidad de inventar mundos nuevos.

Entender la lectura y el pensamiento como creativos, entonces, implica traer la presencia de nuevas imágenes. En el texto no hay ideas e información adentro que debamos descubrir como si éste fuera un contenedor y nosotros exploradoes inmersos en él buscando el tesoro escondido, siguiendo la definición que dimos al inicio de este trabajo. Instaurarnos como evaluadores del texto para decidir qué información es creíble o adecuada implica una actitud que es la del juicio que, por otra parte, llevamos a cabo desde un sistema de creencias y valores al cual adherimos y que, además, nos constituye en nuestro ser y nuestro hacer. La crítica nos permite emitir un juicio positivo o negativo para luego seguir en la estructura de pensamiento conocida. En la lectura creativa establecemos un diálogo con el texto, permitimos que el texto nos hable y nos diga cosas, desde una actitud abierta, suspendiendo el juicio, para que en algún instante de revelación emerjan significados nuevos, relaciones nuevas en redes multidimensionales que rompen la linealidad.

Me parece que estas líneas que he escrito son el resultado del libre juego del pensamiento y ahora no me queda más que someterlas al juicio crítico de ustedes, siguiendo con esta idea de la integración. Tal vez la crítica también sea importante en este ejercicio del pensar. 


\section{De la ironía y del juego}

- Rocco Mangieri

$\mathrm{E}$ $\mathrm{n}$ los lenguajes arquitectónicos y urbanos de las ciudades latinoamericanas, salvo algunas pocas excepciones locales se ha producido, luego del advenimiento de la modernidad en el primer tercio del siglo $X X$ y la progresión de los medios de contacto e información social de orden nacional e internacional, un proceso acelerado de confluencias, mixturas e hibridaciones estilísticas y retóricas de todo tipo. No solamente las clases económicamente altas y los grupos sociales intermedios han sido el escenario de una extensa proliferación de usos y reconfiguraciones estilísticas notables sino que sobre todo las clases y los grupos más bajos en la escala socioeconómica han sido los actores y generadores de una producción arquitectónica cuyo valor, lejos de quedarse en la etiqueta general de un aporte a la cultura popular y nacional, abre un espacio para la reinterpretación de los usos sociales y proporciona un campo para la reflexión teórica y proyectual.

Las ciudades latinoamericanas, en forma semejante a las periferias de las grandes ciudades del mundo, están sembradas de objetos semióticos bizarros y sorprendentes, cercanos al kitsch o al pop-art sin que esto implique el hecho de circunscribirlos como simples anécdotas arquitectónicas y urbanas.
Pueden verse más bien como un verdadero campo experimental que produce fuertes efectos y afectos en aquel mismo sentido apuntado por Herman Broch, Abraham Moles y Umberto Eco en los años setenta, al estudiar y reproponer todo un vasto conjunto de lenguajes de objetos y espacios generados en la cultura de masas.

En un primer momento perceptivo y reflexivo parecen sin duda mensajes y signos objetuales que hacen uso de lo inútil, lo falso, lo superfluo, lo excesivo, de lo que ya ha sido dicho o de simulacros retóricos que recurren a tácticas formales para producir efectos provocadores, gestos sociales de salvación y de consolación en relación con el destinatario y el receptor de estos textos arquitectónicos.

\section{Gramáticas y léxicos bizarros}

Casas, edificaciones, espacios amueblados y decorados, objetos, monumentos construidos en diversos tiempos y localidades deben verse como gramáticas bizarras y fuera-de-código, mucho más lexicales que gramáticas en sentido estricto; objetos configurados ex novo, bien sea por la necesidad y el apremio, bien por la elección dentro del exceso y la abundancia o por la aceptación de una estética del juego y del ludus. En muchas ciudades estas quimeras arquitectónicas y urbanas se

- Escuela de Artes Visuales y Diseño. Laboratorio de semiótica y teoría de los lenguajes, Facultad de Artes, Universidad de Los Andes, Mérida-Venezuela 
nos ofrecen a la mirada como ejemplos del gusto o de un buen gusto estético. Hasta cierto punto (retomando a Kant) tanto desde el punto de vista de una gramática de la producción del objeto como desde la recepción y el consumo visual, estas quimeras parecen dominadas por el desinterés casi absoluto en cuanto trazado de algún fundamento o canon de leyes y reglas de construcción y lectura. En todo caso parecen hechos y pensados para llamar al espectador y confabularlo en el tejido de una figura retórica: producen y generan efectos de seducción. Son en apariencia desviantes en su singularidad pero al poco tiempo revelan rasgos sistemáticos y reiteraciones tales como la exhibición radical, la indicación sumaria, la supersaturación, la repetición, la deformación, la acumulación en todas sus formas narrativas, la cita y la inclusión sorpresiva.

\section{Excesos}

Uno de los rasgos semióticos más relevantes es el exceso de la enunciación y la exhibición misma del engaño, del énfasis premeditado en la muestra ostentosa del objeto, de las incrustaciones y citas cultas o populares de la puesta en escena (a veces teatral) de los elementos formales a partir de los cuales el intérprete debe o puede identificar la procedencia: y origen de las gramáticas, el origen o lugar, personal y anónimo en el caso de las soluciones de orden popular y de la pequeña o mediana burguesía.

Los signos o mensajes de la arquitectura se manifiestan en diversos grados del exceso y la abundancia lo que los incluye de algún modo en una táctica local del neobarroco, analizables históricamente como una operación transgenérica: un punto de vista que creo relevante y necesario para analizar y comprender histórica y discursivamente el diseño, la producción, la distribución y el uso de la arquitectura latinoamericana popular.

Este vasto campo sociocultural de producciones, cada vez más extendido en Latinoamérica, no sólo es un ejemplo de contra-código, de dis-topías y de invenciones retóricas y estéticas, sino que ha dejado de verse como periferia cultural sin más para disponerse como centro de un discurso sobre el tema de la identidad, de la producción y de la significación de la arquitectura y del urbanismo, una vez que se ha reconocido que la aplicación pura y simple de la idea de progreso y modernidad no podía considerarse sin recurrir a un modelo más amplio que tomara en cuenta otros universos de sentido, tanto o más poderosos semánticamente para la lectura y la producción de la arquitectura en Latinoamérica: las memorias históricas de orden rural y campesino depositadas en el saber-hacer de los habitantes urbanos, los vínculos de todo tipo con el mundo y las creencias mágico-religiosas, los imaginarios urbanos configurados sobre la base de las interacciones con los medios virtuales y digitales $y$, en fin, las formas (evidentemente no neutrales e inocentes) de contacto cultural con la postmodernidad y el proyecto post-tecnológico europeo y norteamericano.

\section{Códigos inesperados del gusto}

Junto a una casi aceptación y exhibición de lo falso, vistos como maneras de señalar un código del gusto de orden estético, las burguesías medias y altas locales y en forma progresiva desde los años 
cincuenta y sesenta, han trasladado esta forma de manifestación del discurso desde la casa y la vivienda (villa, casa-hogar, quinta, residencia principal aislada o apareada, casa de campo) hacia otros tipos o modelos funcionales y sociales como el conjunto residencial privado, el sector delimitado y controlado, el edificio de apartamentos y otras soluciones tipológicas como el centro comercial y de servicios.

Pero en éstos últimos es posible, a través del mismo proyecto o de decoración y ambientación, introducir e indicar formalmente los signos y figuras retóricas de un mundo representado como mundo posible de quimeras, sueños del éxito inalcanzable, proyecciones simbólicas de orden colectivo, estereotipos ideológicos o verdaderos exotismos externos (el mundo americano, el mundo tropical, el mundo colonial, el mundo asiático, el mundo andino, el mundo postmoderno).

Uno de los rasgos que diferencia el quiero todo de las soluciones medias y a la aparente selección purista y elegante de las soluciones altas con las operaciones retóricas y plásticas de las soluciones bajas y populares es la casi total ausencia de ironía, de parodia y de humor salvo algunas pocas excepciones. Las quimeras elevadas y elegantes de las casas, villas o edificaciones de la arquitectura capitalina y urbana exhiben una desbordante credibilidad que parece moverse entre un triunfalismo doméstico y una resignación estética que posee varios grados pasionales $y$ emotivos: “...no puedo ni debo mostrar-exhibir todo lo que en el fondo desearía mostrar así que debo seleccionar y elegir los signos y emblemas que sean más oportunos..."

\section{Ostentación e ironía lúdica}

Sabemos que la ironía es una figura retórica que, a través de múltiples formas particulares que pueden trasladarse a la arquitectura y al diseño, hace uso de la relación y del efecto de contrariedad, vinculando en un mismo enunciado o mensaje signos, figuras o estilemas provenientes de diversos espacios a veces muy alejados entre sí. El postmodernismo de lo que denomino como la primera época gloriosa (de Bohigas, Moore, Jenks y otros) se fundaba en la producción de la ironía, de una distancia crítica y reflexiva entre lo dicho y lo no dicho, entre lo expuesto en todas sus partes y sus relaciones tensionales a veces de contradicción, entre la forma explícita del diseño y ciertos indicios de que aquello podría haber tenido otra solución, en el énfasis del proceso tensional y contradictorio del proyecto más que en el efecto canónico y tranquilizador de una forma regular, equilibrada y armonizada con todos los factores del entorno. Los juegos irónicos y por ende estéticos del primer postmodernismo iberoamericano y latinoamericano están dotados de revivals benéficos que lograron reintroducir la estrategia de la cita y del dialoguismo en los procesos e instrumentos mismos del proyecto del diseño, de la arquitectura y del urbanismo: se trataba de volver a visitar con distanciamiento brechtiano un pasado imposible de olvidar pero sobre el cual había que ejercer juicios de valor y selecciones contextuales.

La segunda época postmoderna no fue tan feliz y creo que acabó por dejar de lado la ironía y la crítica para ser arropada y luego confundida en el uso de una retórica que (sin dejar de recurrir a la hibridación formal) se volvió algo seria y académica, 
perdiendo el sentido de lo lúdico y de la autocrítica. La frase postmoderna de combate de los ochenta era everythings goes, pero si es tomada en sentido superficial y literal no permite entender en todo caso el potencial significado del goes, el cual es reeemplazado ideológicamente por todo vale.

\section{Exotismos internos, exotismos externos}

Junto al juego de las ironías estéticas del diseño arquitectónico y de los objetos de uso se colocan también las puestas en escena del exotismo: un exotismo interno como en el caso del mundo colonial, el mundo indígena, el mundo andino, el mundo salvaje y tropical; y un exotismo externo como las representaciones y puestas en escena del mundo europeo, el mundo de las maravillas de la antigüedad, el mundo asiático, misterioso, enigmático y profundo, el mundo moderno americano, etcétera. Los textos y discursos objetuales y arquitectónicos nos hablan de estos mundos representados y nos colocan frente a un vasto campo enciclopédico de sentido que se mueve entre la exhuberancia y la economía, la acumulación desbordante y la escasez disimulada de recursos, la ostentación desesperada y el juego plástico que hace un simple guiño de complicidad al observador, entre la indicación silenciosa de la cita extraída con timidez de un código estereotipado hasta la desenfadada exhibición casi pornográfica de un signo considerado enfáticamente como indicio de una posición social y de un saber enciclopédico hipercodificado.

En estos procesos poéticos y retóricos se incluye sin duda la retransmisión, a veces claramente abierta y lúdica de códigos en una nueva clave aberrante y deformada que solicita directamente una respuesta del observador: acumulaciones de citas lúdicas y llamadas enunciativas que aun incluibles en una esfera del desinterés estético producen efectos de coparticipación ciudadana y la generación de procesos simbólicos de identidad y de localización urbana. Aparece un notable grupo de neos latinoamericanos que reciben éstas $u$ otras denominaciones a través de las reinterpretaciones locales que los mismos inquilinos-propietarios o ciudadanos les otorgan tales como: neochino, neobizantino, californianocolonial, colonial-antiguo, egipcio-modeno, bizantino-moderno, rústico, Luis XIV, oriental, entre otros. Estaríamos a nivel de la representación de los códigos del buen gusto de las clases medias y altas en donde una de las metas principales es la ostentación social en varios grados de iconicidad y de profusión formal.

A partir de esta estrategia global de manifestación de exotismos internos y externos se encuentra, en una lectura más detenida y atenta, una serie muy amplia de signos y mensajes particulares a nivel de los espacios menores, los objetos, los ambientes interiores o exteriores. El listado es casi inclasificable si nos atenemos a un tipo de taxonomía clásica: el uso de grandes rocas y piedras, de ruedas y molinos viejos, de objetos e instrumentos del mundo antiguo o colonial para ofrecer una escenografía de las relaciones de identidad y de creencias de mundos; el uso del mundo vegetal y de las plantas haciendo elecciones, recortes ambientales, enfatizando tipos de plantas y su distribución en el frente o fachada, el recurso a la diferencia entre un mundo vegetal 
seleccionado y ordenado casi como una casa de muñecas y la ubicación de ejemplares o especimenes considerados como signos emblemáticos de la nacionalidad y que remiten a mundos rurales, salvajes o primitivos. Las figuras del mundo vegetal son codificadas y distribuidas en la diferencia entre lo rural y lo urbanístico, lo natural y lo cultural, pero a menudo se pierden sus límites y se difumina la separación neta de su sentido (el cambur y el cactus salvaje es domesticado y se entreteje con la vegetación más urbanística y más culta).

\section{Retóricas híbridas y cultura popular}

En este vasto proceso ha predominado el ejercicio casi permanente con algunos altibajos, de una retórica construida a partir de las representaciones del mundo colonial y postcolonial. Al menos hasta los noventa pilones, hamacas, altares y crucifijos, patios, columnas, techos de tejas, ventanales, rejas y la evocación o réplica de la forma de la casa o del edificio, constituyen los signos y los símbolos de un imaginario ciudadano sobre el tema de la identidad social e histórica.

En este sentido, por ejemplo, es notable en Latinoamérica la cita y recurrencia a los signos y figuras del mundo colonial como táctica de identificación y de separación simbólica de clases o grupos socioeconómicos. Aquí reaparece un código de lectura basado en la relación espacial alto/bajo porque de hecho la reivindicación ostentatoria de las formas y los objetos del mundo colonial es un símbolo no sólo de ascenso en el espacio social sino sobre todo de permanencia en otro nivel. El uso y comprensión o manejo simbólico de los signos del mundo colonial se convirtieron en un cierto momento en un signo social de ascenso así como lo fueron después todos los usos y traducciones locales (exitosas o no) de los signos y textos arquitectónicos de la modernidad y la posmodernidad que formaron y forman parte de una historia y de una teoría de la arquitectura y del diseño latinoamericano.

Notamos las múltiples formas y procedimientos a través de los cuales las retóricas híbridas de las casas y edificios de las clases medias y altas oscilan entre las valorizaciones utópicas de mundos posibles exóticos internos, externos o simplemente imaginarios. Estos mundos representados pueden corresponder a verdaderos estereotipos reductores de la significación o, por el contrario, a aperturas imprevistas de soluciones creativas. Pero el espacio donde se manifiesta un ejercicio más deliberadamente lúdico y hasta decididamente provocador es sin duda en el contexto sociocultural de los grupos socioeconómicos más bajos o medios, cuyo diálogo con el componente más vivo y enérgico de la comunicación social y artística vinculada a la tradición y a la creatividad de las culturas populares nunca ha dejado de establecer canales y espacios de contacto.

Los signos kitsch, pop o folk de las casas, viviendas o edificaciones del universo popular $y$ periférico no dialogan casi nunca con la retórica del triunfalismo, de la ostentación radical o de la desilusión y la aceptación de unos límites económicos de la enunciación. Más bien citan el gusto de los otros pero a través de deformaciones estilísticas y morfológicas que acompañadas de valoraciones lúdicas y prácticas hacen del signo visual una suerte de enciclopedia local del gusto basada 


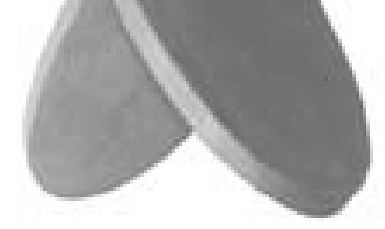

más que en el juego de la interpretación que en la puesta en escena de un emblema de identidad, de posición o de autoreconocimiento.

\section{Originales y réplicas}

En definitiva, si conectamos la mirada desde una semiótica y una poética de la arquitectura con el tema del valor social del original y sus réplicas notamos que la preocupación y el estado pasional y pulsional de acceso a un original valioso es mucho más latente en unos grupos que en otros. De hecho, en el universo de las culturas populares este objetivo es casi nulo y la repetición de morfologías y soluciones se produce con mayor uniformidad y homogeneidad tendiendo a la configuración de lenguajes que permiten variedad en la unidad, sorpresas en la continuidad de un código bastante estable.

El deseo explícito, oculto o semioculto, denegado pero latente, de poseer un original (la mejor casa del arquitecto, la casa emblemática, el edificio más representativo...) o, en su lugar, y haciendo juego con lo anterior, el deseo de tener todo o casi todo, de poseer y de mostrar al otro un ejemplar o un espécimen de todos los trozos de la arquitectura que nos gusta quizás sea una tendencia bastante extendida o universal, y de hecho sabemos la relevancia que han tenido siempre los eclecticismos a través de varios momentos de la teoría y la historia de la arquitectura y del diseño. Pero no me atrevería a confirmarlo, pues creo que se origina y se hace prolífica en los entornos socioculturales presionados por un afán de adquisición y competencia que no puede entenderse como un signo negativo en forma radical pero que no incide satisfactoria y plenamente en los usos-lecturas y producciones simbólicas de la arquitectura y la cultura latinoamericana. Creo que de algún modo las operaciones retóricas y poéticas, bien sean del saber-hacer del diseñador, bien provenientes de los ciudadanos y las comunidades anónimas populares, marginales o elitescas y confinadas, deben suponer un juicio de selección y de valor. Estos valores deben ser colocados antes o después del objeto de diseño y a partir de estas lecturas, algo distanciadas y críticas, poder reconstruir un recorrido genético y localizar causas, relaciones y procesos de formaciones discursivas.

Todo esto no tiene por qué excluir nuestra propia sorpresa estética o estésica en relación con los efectos y los afectos que sin duda producen sobre el mismo analista e investigador colocado frente a la potencialidad significante y comunicativa de estas quimeras arquitectónicas que enriquecen el mundo y nos recuerdan que casi siempre las lecturas y las gramáticas de los usuarios y de los ciudadanos son diversas y transgreden las gramáticas presupuestas en los lenguajes, las tipologías o las soluciones ofrecidas desde el espacio de los especialistas y los profesionales. 


\section{Elementos del patrimonio monumental francés en México*}

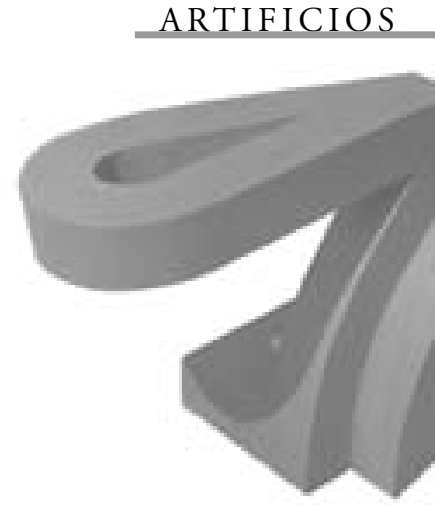

$\mathrm{L}$ a aventura política francesa en México dejó para el recuerdo algunos monumentos realizados no sólo por sus arquitectos sino por artesanos locales. La Revue Générale de l'Architecture (en adelante RGA), da cuenta, en 1872, de algunas obras realizadas en América por artistas franceses, como el Monumento conmemorativo del 2 de mayo de 1886, erigido en Lima (Perú) por E. Guillaume, una columna rostrada de fuste acanelado, flanqueada de cuatro figuras alegóricas y terminada por una victoria alada llevando una espada. La RGA publicó también la Tumba del Général Vernhet de Laumière, concebida para el cementerio de Puebla, donde las tropas francesas fueron derrotadas por la armada mexicana el 5 de mayo de 1863. Fueron los propios oficiales quienes financiaron y supervisaron la realización de este mausoleo construido a la memoria de su general: “Ejecutado en París, según el dibujo de $M$. León Duprè, el monumento fue expedido a México; llegó en el momento mismo en que nuestras tropas se reembarcaron hacia Europa y fue erigido bajo los cuidados del cuerpo de ingenieros militares, en una capilla especial de la Iglesia de Puebla, arriba del féretro donde el general había sido inhumado". ${ }^{1}$

En el mismo panteón, y por los mismos combatientes de 1862-1867, el arquitecto de Bellas Artes, Morin-Goustiaux, asistido por el estatuario Jules Dubois, construirá a finales de siglo un gran arco ecléctico. Auguste Genin, cronista de la historia francesa en México, señala la existencia de otro mausoleo realizado por un francés de Puebla, con bajo presupuesto y con el apoyo de artesanos mexicanos, que el mismo Genin consideró como "nada especial". ${ }^{2}$ En México, el cementerio francés, o Panteón de la Piedad, fue fundado en 1865 con el consentimiento del jefe del cuerpo expedicionario, el Mariscal Bazaine, para dar sepultura a los soldados víctimas de la expedición. Sus cuerpos se encuentran todavía allí, en una fosa mal preservada. El panteón cuenta con un Monumento a los Muertos de la Guerra de 1914-1918, a la que los franco-mexicanos enviaron a un buen número de sus hijos. Construido en hemiciclo, el memorial es obra del arquitecto francés Paul Dubois, radicado en México en los años veinte, quien realizó, entre otros proyectos, el hospital de la Sociedad de Bene-

\footnotetext{
* Traducción de Lucía Martínez Moctezuma.

1 “Tombeau du Général Vernhet de Laumière, protagoniste de la bataille de Puebla, par Léon Dupré, architecte", en Revue Générale de l'Architecture (RGA). XXIX, 1872.

${ }^{2}$ A. Genin. Les français au Mexique, du XVle siècle a nos jours. París, Nouvelles Editions Argo, 1933.
}

- Historiadora del arte, Investigadora asociada al Centro Francés de Estudios Mexicanos y Centroamericanos. Profesora visitante de posgrado, Facultad de Artes 
ficencia Francesa ${ }^{3}$ y la sede del principal consorcio textil de Orizaba, Veracruz, la Cidosa, ${ }^{4}$ heredera de las grandes fábricas franco-belgas creadas durante el Porfirismo. La capilla neogótica de La Piedad se debe también a un arquitecto de origen francés: Èmile Desormes. Instalada en la mira, al fondo de la avenida central, se inscribe en la tradición mexicana de las capillas privadas y participa de su eclecticismo: decorada con una gran flecha central metálica, atípica para las normas de la época. Se podría escribir de diferentes maneras la historia francesa de este bello cementerio romántico, sí, a pesar de que su creación, su gestión y la gran parte de los muertos ahí enterrados son franceses, la estatuaria, el arte de las tumbas y esta arquitectura ya atestiguaban un devenir americano de las formas europeas.

Dos modestas pirámides, todavía en pie, fueron construidas en la Isla de Sacrificio, Veracruz, y en el cementerio de Ciudad del Carmen, Campeche. Monumentos precarios para los cuales los cónsules regionales reclamaron a su ministerio que mostrara más interés en su cuidado y que en la actualidad siguen en el olvido de las autoridades diplomáticas. Una placa sobre la estela de Campeche dice lo siguiente:

“A la memoria de los marinos de la artillería La Grenade, muertos de fiebre amarilla en su paso por El Carmen. Expedición de México, 1862. En recuerdo de sus camaradas. 2 de febrero 1863.

El comandante de La Grenade, R. Rocquart”
En el poblado de Camarón, en el estado de Veracruz (Cameron en francés, como para borrar las connotaciones triviales del nombre de origen), se quedó en el imaginario postcolonial francés como el mítico lugar de la derrota en México, donde quedó como testimonio un mausoleo a la memoria del pequeño grupo que fue exterminado en plena resistencia. Por el cual México ha construido también un monumento con el fin de que la historia no sea leída de una sola manera.

En 1854, el industrial Antonio Escandón ofreció a la Ciudad de México una gran fuente de hierro colado fabricada por la fundidora francesa Le Val d'Osne, reclamando el reembolso de los gastos de expedición que seguramente fueron bastante elevados. ${ }^{5}$ Será el primero de una larga lista de pedidos hechos a Le Val d'Osne para decorar la Alameda, debido al Movimiento Verde de los años ochenta que incitará a perfeccionar los decorados urbanos. Posteriormente llegarán algunas alegorías de las estaciones del año producidas por el mismo conjunto de empresas, un Mercurio alado según Gianbologna, seguido de dos fuentes; El Manantial (La Source), modelada por el escultor Sauvageot; y Las Musas de la fuente por Albert-Ernest Carrier Belleuse (1824-1887), gran especialista de esas obras de arte industrial y una personalidad artística de la triunfante III República.

Un segundo ejemplar de Las Musas se encuentra en la antigua hacienda de Manuel González, hoy Universidad Agrícola de Chapingo, en el Estado de

\footnotetext{
${ }^{3}$ Exactamente Sociedad de Beneficencia Francesa y Suiza, que devino de Sociedad Francesa, Suiza y Belga de Beneficencia y Prevención, a simplemente Beneficencia.

${ }^{4}$ Compañía Industrial de Orizaba S. A.

${ }^{5}$ Archivo Histórico de la Ciudad de México (en adelante AHCM). Paseos en general. Libro 1885. Expediente 110, 1854.
} 
México. González lo adquirió junto con una serie de obras metálicas por la intermediación de su arquitecto, Antonio Rivas Mercado. En 1890, un Nacimiento de Venus de Mathurin Moreau (18221912) fue instalado en una de las últimas glorietas de la Alameda que aún quedaban sin decorar, en perjuicio de la opinión de la prensa conservadora, molesta frente a la inquietante desnudez de la Venus. ${ }^{6}$ Finalmente, un Neptuno de Vital-Gabriel Dubray (1813-1892), embelleció desde 1889 una fuente ofrecida a los ediles mexicanos por un grupo de negociantes franceses que deseaban construir y explotar en la Alameda un café restaurante, el Pabellón Parisino. Hicieron el pedido del plano y los materiales de construcción a Francia $^{7}$ pero dos naufragios sucesivos les impidieron recibir los elementos de la estructura. La pérdida del fierro obligó a los concesionarios a la anulación del contrato, "un caso fortuito o de fuerza mayor" que aminoró las diferencias que para entonces ya existían entre ellos. ${ }^{8}$ De esta manera, el Ayuntamiento conservará el Neptuno pero perderá la oportunidad de tener en el centro de la Ciudad de México un edificio francés, por el nombre, el estilo, el fierro y el origen de los propietarios. Durante este tiempo, en un prado vecino, un especialista del arreglo de los jardines, Víctor Fournier, construyó un invernadero. Mínimo ejemplo, cuando se sabe de la importancia del fenómeno paisajista francés en América.

Tres monumentos nacionales fueron marcados por la idea o incluso por la factura francesa. Como el monumento a Cristóbal Colón que Ramón Rodríguez Arangoiti (1832-1884) debía realizar y que Antonio Escandón decidió confiar al escultor francés Charles Codier (1827-1905), asociado con el arquitecto Charles-Francois Rossigneux (18181909). Constituido por un pedestal macizo en mármol rojo de los Vosgos, soportando a Colón y a cuatro monjes evangelizadores de la Nueva España, el memorial fue presentado en los Campos Elíseos antes de viajar a México en 1877. Originalmente debía colocarse frente a la Estación de Ferrocarril de Buenavista pero se instaló en el centro de una de las glorietas de la Avenida de Reforma, siguiendo el orden de las procesiones hacia el parque de Chapultepec, detrás del Caballito de Tolsà y previo al Monumento a Cuauhtemoc, obra maestra del neoprehispanismo. En un panfleto editado por cuenta del autor, Rodríguez Arangoiti criticará la parte arquitectural e iconográfica de este monumento, en el cual los capitalinos nunca llegarán a reconocerse.

El Monumento hipsográfico, encargado en 1877 por el General Vicente Riva Palacio, desde el ministerio de Fomento, se debe en parte a la Francia.

\footnotetext{
6 "La estatua de la Alameda. Malicias de los mochos" en El Partido Liberal, México, viernes 17 de enero 1890, citado en Ida Rodríguez Prampolini. La crítica de arte en México el siglo XIX. México, UNAM-IIE, 1964, pp. 243-244.

7 "La construcción se hará en hierro y cristal sobre bases de cantería labrada y circuito de plantas escogidas y preciosas flores. Actualmente la distinguida concurrencia que asiste a la Alameda carece de un sitio en donde descansar o tomar algún refrigerio, separándose del movimiento general de la multitud, pues que los cafés y salones se encuentran muy distantes de aquel paseo". AHCM. Paseos y Jardines. Libro 3590. Expediente 344, 1889.

${ }^{8}$ Socios (Achille Weil, B. Biquard et Cìa. Eduardo Schweitzer) contra fiadores (Leon Honorat, Leon y Antonio Signoret), ibid.
} 
Riva Palacio quería celebrar las obras del Drenaje del Valle de México a través de la figura del ingeniero Martínez, que evocaba su dimensión herculeana. “La estatua que deberá rematar el Monumento, es una alegoría de la Ciudad de México en el acto de depositar una corona sobre una piedra votiva, con la inscripción: Enrico Martínez". ${ }^{9}$ Concebida por el escultor Miguel Noreña, la grande Matrona será realizada en bronce por los hermanos Thiébaud cuya Casa en París fundirá los relieves a semejanza de los dioses y héroes del panteón mexica, que diseñó Jesús Contreras (1866-1902) para decorar el pabellón de México en la Exposición Universal de 1889. Contreras de regreso a México creará en 1892 su propia fundidora de bronce, la Fundición Artística Mexicana, de donde saldrá la estatuaria metálica de los principales monumentos públicos de la última etapa del porfirismo.

La Fundidora Artística producirá numerosas copias de obras antiguas y del Renacimiento que fueron distribuidas por toda la ciudad, y para la Alameda realizará una copia en bronce de una "estatua en carne" del escultor suizo James Pradier (1790-1852), cuyo original pertenecía a las colecciones de la Academia.

En 1910, una gran estatua de Pasteur fue ofrecida a la Ciudad de México por la comunidad francesa para celebrar las Fiestas del Centenario, misma que se instaló sobre una plazoleta reservada en el Paseo de la Reforma, donde de manera simultánea se plantó un ahuehuete, el árbol del centenario. La estatua era una copia de la realizada a principios del siglo XX por Jean Antonin Carles (18511919) para la ciudad natal del biólogo Dôle en el Jura. Fue fundida por Durenne.

Otro aspecto que debe tomarse en cuenta es la esporádica intervención de los gabinetes franceses de arquitectura que fueron solicitados para la construcción de casas, un caso poco frecuente, a pesar de que el imaginario nacional encuentra en ello una razón principal del afrancesamiento de la arquitectura porfiriana. Cuando se hacían estos encargos, ¿los arquitectos franceses hacían el viaje a México? Seguramente no. Cuando concibió los planos del gran edificio de los barcelonetas, Las Fábricas Universales, fundado en 1893 e inaugurado en 1909, Eugène Ewald muy probablemente no salió de París. Se encargó de la construcción Miguel Ángel de Quevedo, quizás beneficiándose de algunos planos preexistentes del arquitecto. La reticencia de Emile Bénard por finiquitar personalmente sus pedidos americanos revela un fenómeno de la época: el viaje seguía siendo un negocio de aventureros, los profesionales experimentados se resistían al desplazamiento.

De hecho, ¿qué quedó del Palacio Legislativo concebido para la Federación por Emile Bénard?, su obra "magistralmente sin terminar", según una biógrafa francesa. ${ }^{10}$ Un "siniestro ejercicio... un templo, un aborto de arquitectura monumental"

\footnotetext{
${ }^{9}$ Memoria del Ministerio de Fomento. Colección Industria y Comercio. Condiciones del monumento Hipsográfico. Documentos Anexos, núm.1, México, 1882.

10 S. Chouard. Emile Bénard, un inspirateur méconnu (1844-1929). Memoria de maestría. Universidad de Paris IVSorbona, Instituto de Arte y Arqueología, 1995.
} 
(esta misma biografía juzgando el nuevo empleo que se hizo de la estructura metálica de la cúpula, única manufactura realizada antes de la Revolución). De hecho, se trata de un ejercicio de recuperación simbólica, manifiesto de los años de realismo socialista y confiado a uno de los devotos del periodo, el arquitecto Obregón Santacilla (1896-1961). La estatuaria imaginada por Bénard para decorar su Palacio y confiada por él a cuatro escultores franceses será distribuida felizmente en la ciudad. El par de leones en bronce concebidos por Georges Gardel (1863-1939) para el pórtico, se instalarán a la entrada del Parque de Chapultepec, y dos grupos realizados por André-Joseph Allar (1845-1926); La edad viril y La Juventud, cariátides para el frontón, serán integrados a la fachada del Palacio de Bellas Artes para el que parecen haber sido realizados. ${ }^{11}$ Cuando construye su casa en Mixcoac, a los alrededores de la Ciudad de Mexico, Emile Bénard concibe una residencia con materiales como el tabique y el tezontle (lava volcánica) que es necesario comparar con las casas normandas que realizó, pero sobre todo confrontar con el estilo porfiriano. Pierre Bénard, su hijo, creará en Tlalnepantla una fábrica de azulejos de cerámica, para la cual Èmile proporcionará algunos bellos dibujos. ${ }^{12}$ Él había seguido en Bellas Artes una formación paralela de pintor y deja una obra convencional de donde emergen vistas mexicanas romanizadas.

La investigación sobre el patrimonio monumental francés en México no carece de obstáculos, pues la crónica del siglo XX se complació exageradamente en reconocer una paternidad francesa a las realizaciones durante el siglo de la Independencia. La historia constructiva fue particularmente manipulada. Así es el caso de la iglesia metálica de Santa Rosalía, en Baja California, que por razones mediáticas fue atribuida a Gustave Eiffel (padre, por antonomasia de todos los edificios de fierro), cuando los directivos del centro minero El Boleo la compraron a otro constructor, el brasileño Bibiane Duclos, por cierto formado como ingeniero en Francia e instalado en este México. ${ }^{13}$

En cuanto al afrancesamiento de la arquitectura porfiriana, en sí, es un tema construido por la posrevolución para caracterizar al régimen de Díaz, mostrando que estaba sometido al poder de representaciones y modelos extranjerizantes. ${ }^{14}$

\footnotetext{
${ }^{11}$ Ibid.

${ }^{12}$ Expediente iconográfico, $2^{\mathrm{a}}$ sección, "Emile Bénard pintor”, ibid.

${ }^{13}$ F. Dasques. “¿La iglesia de Santa Rosalía: un edificio Eiffel?”, en México en el Tiempo, mayo-junio 1995.

${ }^{14}$ La terminología se debe a José Villagrán García, siguiendo a Manuel Gamio (Forjando Patria), ambos actores de esta construcción mental.
} 


\title{
La libertad de articulación
}

\author{
- Lydia Elizalde
}

$\mathrm{E}$ I análisis semiótico de las variables visuales permite explicar los fenómenos artísticos contemporáneos. En una escultura se identifica la constitución de la materia con la que el autor trabaja. Se relacionan los elementos de la sustancia de la expresión, el color del material, su textura física, la visual, para aislar un sistema de relaciones de nivel físico-técnico del semántico. La configuración de las formas, aunque sean reducciones es reconocible, son formas que proponen significados.

Estas se constituyen a nivel del signo, a pesar de que no puedan ser codificadas ni definidas claramente. En estas formas existen idiolectos, tendencias, que unen las variables del código físico individualizado. Umberto Eco afirma que en casi todas las obras de arte contemporáneas se destaca la fundación de un código individual.

Al insertar las esculturas en un espacio público abierto, se crea un sistema de articulaciones entre ellas y el entorno: jardines, explanadas, vestíbulos, recorridos peatonales, que formulan nuevos mensajes y denotan otros sistemas de funciones.

Los cambios climáticos y de luz y la colocación de las obras en estos espacios proporcionan al receptor un indicio de formas codificadas que se integran en áreas transformadas previamente por el humano. Las esculturas de Pawel Anaszkiewicz, en este espacio recreado, son signos en relación a sistemas.
Las instalaciones de este artista son otra propuesta escultórica donde presenta obras que por su disposición, escala y dirección expresan diversos significados en un espacio cerrado para ser transitado y experimentado por el receptor. Espacio donde la escultura es reconstruida. Aquí, el autor confiere a estas formas una nueva significación al interrelacionarlas entre sí y resignificar su discurso por medio de la yuxtaposición de las características plásticas de los materiales que utiliza -acero oxidado, galvanizado e inoxidable- hierro, resinas epóxicas y de poliuretano.

El código gestáltico de la escultura geométrica y de la composición escultórica en la instalación comprende además los contornos recreados, la definición de los planos y líneas de perspectiva; y contiene las connotaciones culturales para su interpretación, alternativas de lectura, de juego, de indicio a partir de formas, imágenes y luces, y en ocasiones de sonidos.

Los objetos tridimensionales que conforman estas instalaciones tienen influencias de un medio artístico, de estilos y tendencias, del momento histórico en que se realizaron y de su economía, así como del lugar para el que fueron creadas o donde se encuentran, y de las cualidades comunicativas para transmitir una experiencia emocional o conceptual.

- Profesora-Investigadora, Instituto de Ciencias de la Educación - Facultad de Artes 


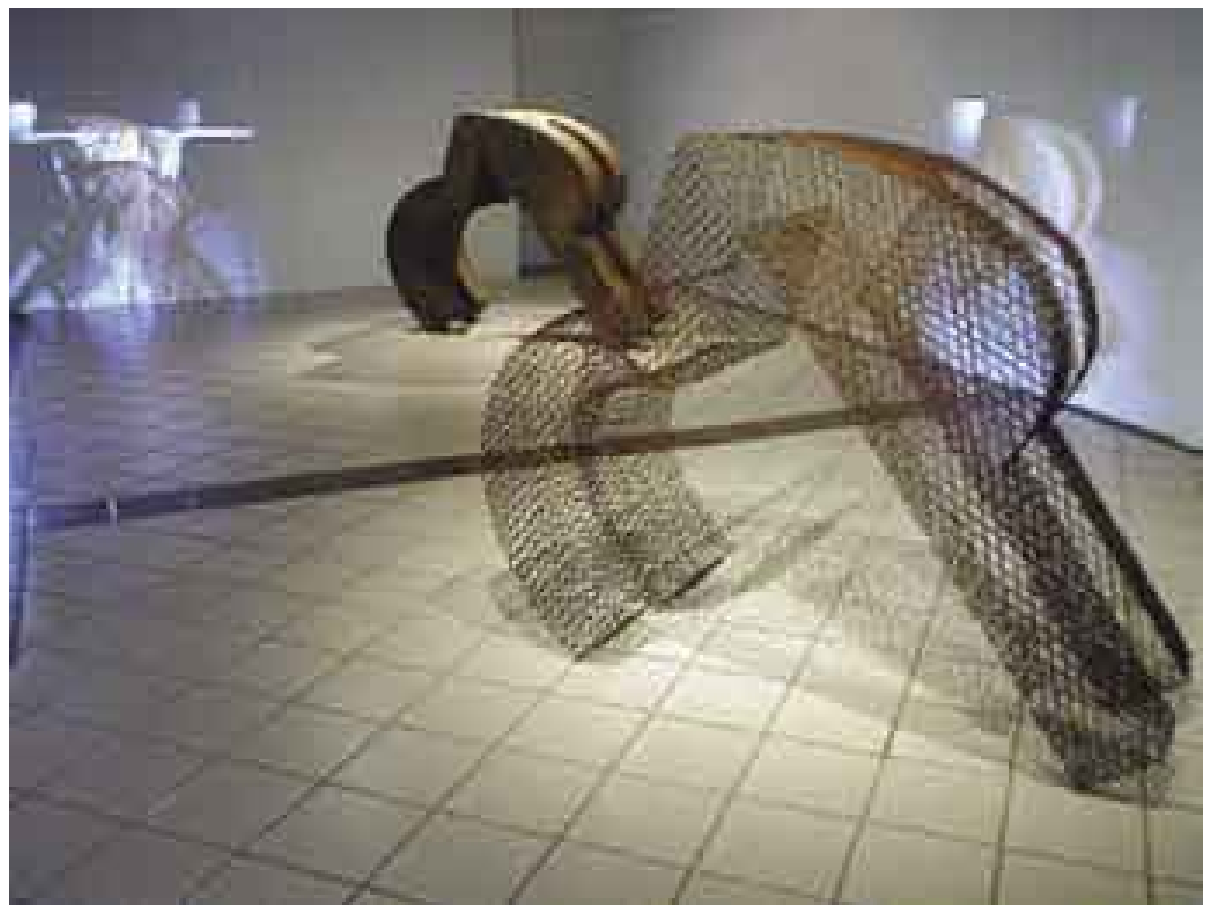

En virtud de lo actual, instalación esculturas-videos, Jardín de las Esculturas, Jalapa, Veracruz, 2003

- Pawel Anaszkiewicz, profesor de Escultura en la Facultad de Artes 


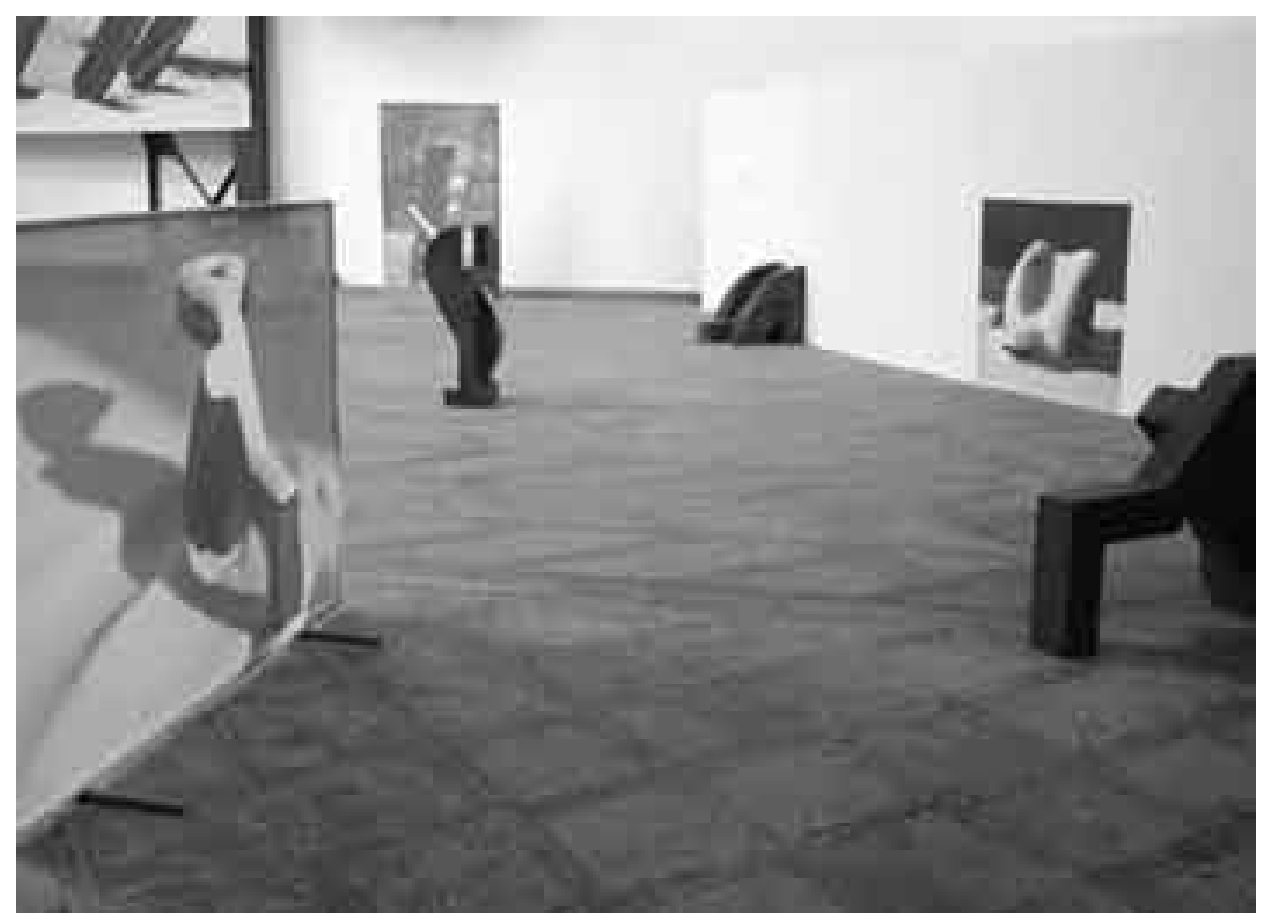

Exposición Memoria blanca de los nahuales, Museo Universitario del Chopo, Ciudad de México, 2002 


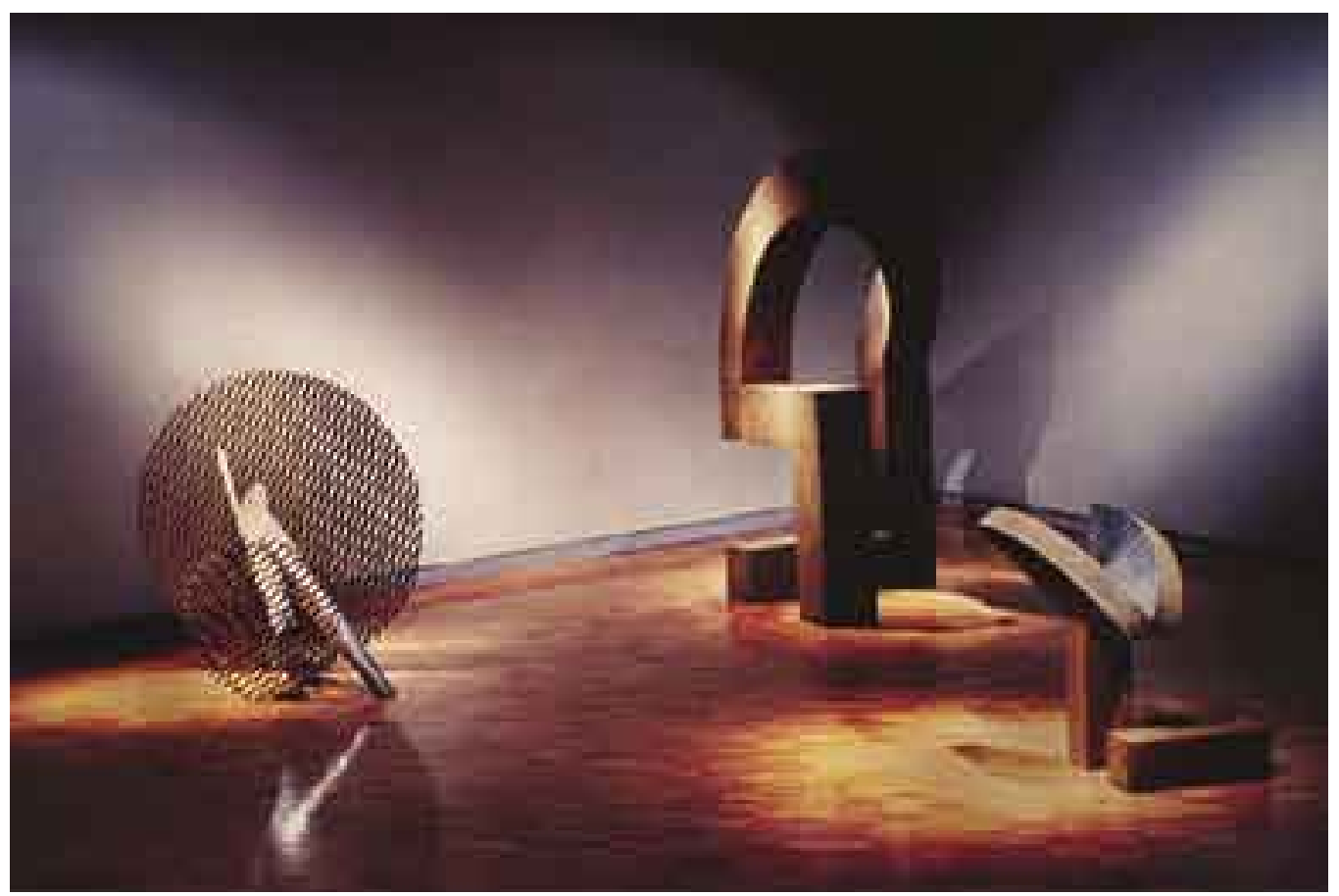

Exposición en el Museo de Arte Moderno de la Ciudad de México, 1998 


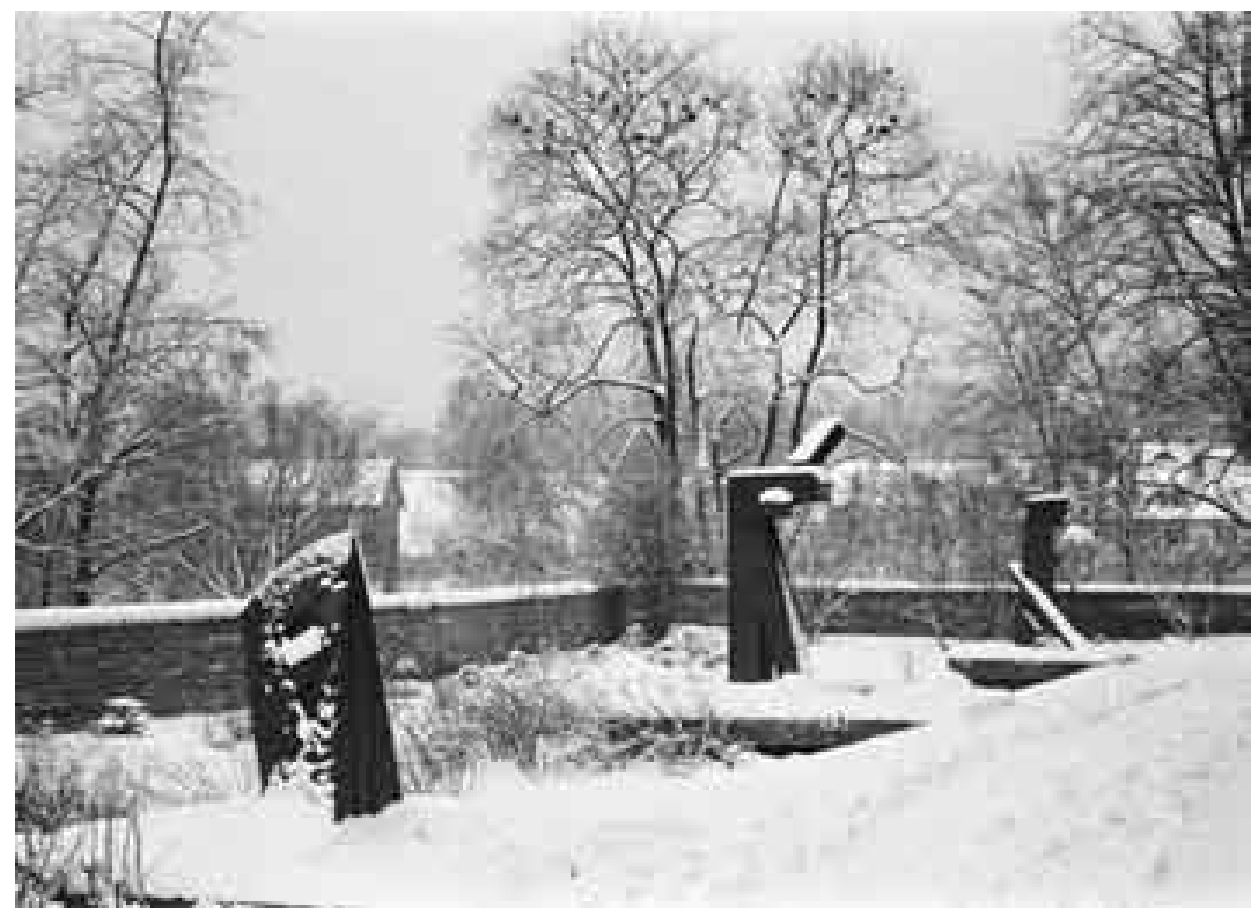

Esculturas en el Jardín de la Sociedad de Artistas Plásticos de Polonia, Castillo de Olsztin, 1999 


\section{A ver}

- Juan Gelman

En la tarde de al lado vive

una vieja que pide para el pan.

Así se calla el universo

con esa piedra encima y

lo que hiere

del dulce amor. La

canción de las raíces es

atravesada parte a parte

por una piedra que tiró

la tarde de al lado con

la lejanía de los grillos y

su efigie calcinada

en una boca grande abierta.

México, 2005 


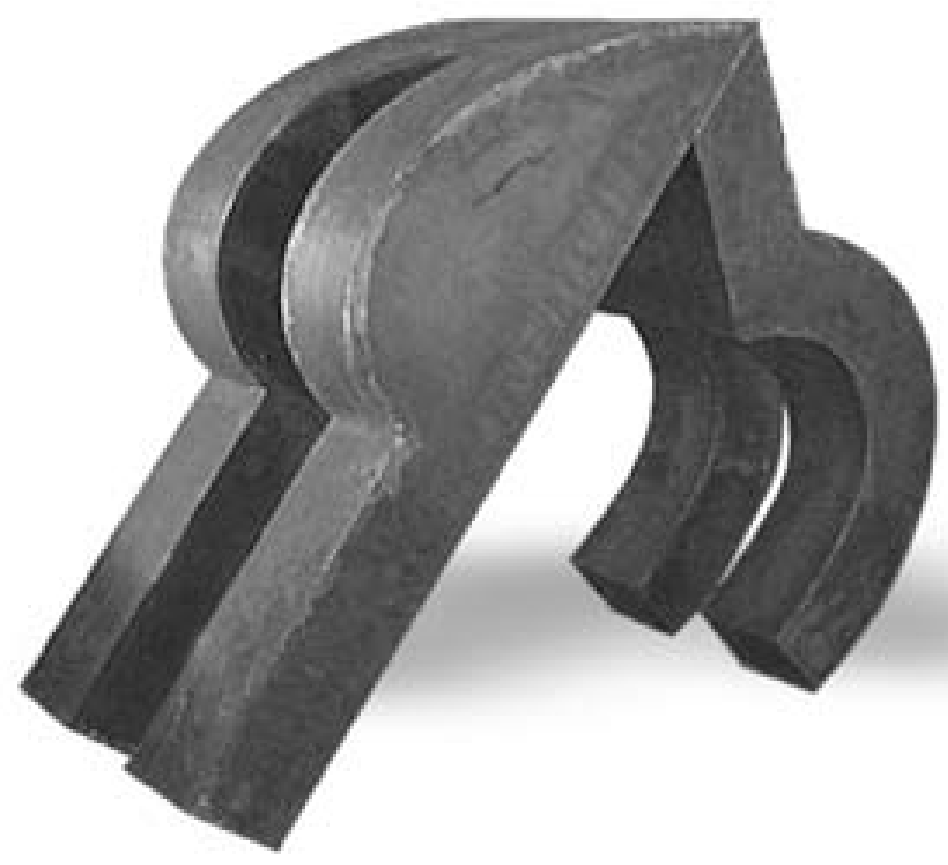

Escultura \# 2, 2001 


\section{CÁTEDRA ALFONSO REYES}

\section{La persona de Hernán Cortés}

- José Luis Martínez

G

abriel Lobo Lasso de la Vega, en su poema

épico cortesiano, escribió que, para salvar a la iglesia, Hernán Cortes nació

...en el año mismo que Lutero

monstruo contra la iglesia, horrible y fiero

lo cual es falso, porque mientras Cortés nació en 1485, sin que se conozca el día, Lutero nació, según recordaba su madre, el 10 de noviembre de 1483, víspera de San Martín.

En 1485, Bartolomé Díaz dobla el cabo de Buena Esperanza. En el México antiguo, año VI, calli, Tizoc es señor de México y Nezahualpilli de Tezcoco. Y fueron contemporáneos de Cortés, Garcilaso de la Vega y Fernando de Rojas, Nicolás Maquiavelo, Miguel Ángel, Leonardo da Vinci, Tiziano, Giorgione y El Bosco.

Sus padres fueron pobres, cristianos viejos, aunque en Medellín tenían un molino de trigo, un colmenar y una viña. Catalina, su madre, era "recia y escasa" y su padre había hecho la guerra cuando joven. Hernán, hijo único, se crió enfermo y estuvo a punto de morir. Lo salvó su ama de leche, María de Esteban, y una devoción al apóstol San Pedro.
A los catorce años sus padres lo enviaron a la Universidad de Salamanca y en esa ciudad vivió en casa de Francisco Núñez de Valera, que enseñaba latín y estaba casado con una media hermana de su padre. Aprendió latín pero no siguió los estudios por unas fiebres cuartanas. Sus padres lo querían licenciado, pero el mozo, "bullicioso, altivo, travieso, amigo de armas y enamorado“, traía perturbada a la casa paterna y el pueblo. Cuando estaba a punto de partir, por encontrar una mujer cayó de una barda y tuvo que guardar cama. Ya sano, vagabundeó por algún tiempo y anduvo por Valencia, y en Valladolid durante más de un año se asentó con un escribano y aprendió bien este oficio.

Al fin, a los diecinueve años, con la bendición y auxilio de sus padres, viajó a las Indias, y tras de una travesía accidentada, llegó a la isla Española. Por la ayuda que prestó en la pacificación de alguna región de la isla, el gobernador Ovando le dio indios en encomienda y la escribanía del ayuntamiento de Azua.

Cuenta Cervantes de Salazar que, contrastando con las estrecheces en que vivía, Cortés le contó que soñó que estaba vestido con riqueza y servido

- Miembro de la Academia Mexicana de la Lengua. Texto leído el 18 de diciembre de 2005 en el Museo Cuauhnáhuac del Palacio de Cortés, Cuernavaca, Morelos. 
Y, para finalizar, bebía chocolate, fumaba y reposaba un poco.

Además de grasas los españoles carecían de todo estimulante, que sí tenían los indígenas (pulque, tabaco, hongos) pues les faltaba su vino y aún no aprendían a fumar.

Durante los días de luchas encarnizadas con los tlaxcaltecas -antes de que se amistaran y aliaran, en que todos estaban heridos, a Cortés le dieron, además, calenturas. Y cuenta Andrés de Tapia que decidió purgarse con ciertas píldoras que traía de Cuba. Tragó un pedazo de aquella masa pero los atacaron los tlaxcaltecas y Cortés cabalgó y peleó todo el día. Por la noche le preguntaron sus soldados cómo le había ido de su purga, y dijo que se le había olvidado "e purgó otro día como si entonces tomara la purga “.

Durante los ocho meses de paz que tuvo Cortés en la ciudad de México, con Moctezuma cautivo, hubo tiempo para muchas cosas, ${ }^{1}$ por ejemplo el juego, al que Cortés era tan aficionado. Y con el melancólico señor azteca, el hispano aprendió a jugar el totolli o totoloqui, una especie de bolos de los antiguos mexicanos. La cuenta de Cortés la llevaba Alvarado y la de Moctezuma un sobrino suyo. Refiere Bernal Díaz que el señor de México advirtió que el Tonatío - Alvarado "siempre tanteaba una raya de más" y que hacía trampas para que ganase
Cortés, aunque las ganancias de uno u otro se repartían entre los asistentes.

La expedición que organizó hacia Honduras -entonces llamadas las Hibueras- en octubre de 1524 para castigar una infidencia fue una catástrofe. Salió de la ciudad con una enorme comitiva, como un príncipe del Renacimiento, con vajillas de oro y plata, saltimbanquis y músicos. La Malinche y Cuauhtémoc, y una piara de puercos iban con él. Y decidió cruzar el istmo de Tehuantepec por donde no había camino, sino enormes ríos y pantanos. Cuando había pasado casi cinco meses del viaje, Cortés acusó a Cuauhtémoc de que intentaba sublevarse y ordenó ahorcarlo en Acalan, donde hoy es Campeche. Bernal Díaz comentó que "fue esa muerte que les dieron muy injustamente y pareció mal a todos los que íbamos". Cortés, dice el mismo cronista, "andaba mal dispuesto y muy pensativo y descontento", "de noche no reposaba [...] y descuidóse y cayó de dos estados abajo y se descalabró en la cabeza, y calló, que no dijo cosa buena ni mala sobre ello".

Cuando terminó esta terrible expedición a las Hibueras, Bernal Díaz cuenta la impresión que le hizo Cortés cuando Gonzalo de Sandoval y él lo encontraron en el puerto de Trujillo: "estaba tan flaco, que hubimos mancilla de verle, porque según supimos, había estado a punto de morir de calen-

\footnotetext{
1 Para ejemplificar la manera en que para Cortés "hubo tiempo para muchas cosas" se incluyen en este artículo las notas 1,2 y 3 con testimonios y declaraciones tomadas de los diversos Documentos Cortesianos que ilustran este periodo.
} 
turas y tristeza que en si tenía [...] y dijeron otras personas que estaba ya tan a punto de morir, que le tenían hecho unos hábitos de San Francisco para que le enterraran con ellos [...] y que tenía tanta pobreza que aun de cazabe no nos hartamos..."

Pero vuelve a la ciudad de México, reasume su gobierno que le quitara un juez que llega ha hacerle un juicio de residencia, que entonces no prospera. Viaja a España en 1528 para defender su causa y logra ver al emperador Carlos $V$ de quien recibe honores y mercedes pero no el poder en la Nueva España.

El rey ordena que se le haga juicio de residencia, que nunca se concluye. También se le procesa por la muerte de su primera mujer, Catalina Xuárez, que termina sin juicio.

En 1540, cuando tiene ya 55 años, viaja de nuevo a España para tratar de arreglar su situación, y se entera de que no puede volver a Nueva España hasta que se resuelvan sus juicios de residencia. Va de mesón en mesón tras de la corte itinerante, y escribe al monarca sus cartas de agravios. Hay en ellas cierta elevación en la amargura, como de quien sabe la importancia de sus acciones, ve cómo se han desvanecido el poder y la gloria y ha venido a convertirse sólo en un litigante molesto. La última de estas tres cartas es la "sentidísima" del 3 de febrero 1544 en la que los agravios acumulados en el alma le salen incontenibles:

Pensé que haber trabajado en la juventud me aprovechara para que en la vejez tuviera descanso, y así ha cuarenta años que me he ocupado en no dormir, mal comer y a las veces ni bien ni mal, traer las armas a cuestas poner la persona en peligros, gastar mi hacienda y edad, todo en servicio de Dios, trayendo ovejas a su corral muy remotas a nuestro imperio [...] y acrecentando y dilatando el nombre y patrimonio de mi rey [...] y trayéndole a su yugo y real cetro muchos y muy grandes reinos y señoríos [...] ganados por mi propia persona y espensas, sin ser ayudado de cosa alguna, antes muy estorbado por nuestros muchos émulos e invidiosos...

Véome viejo y pobre y empeñado en este reino en más de veinte mil ducados [...] he sesenta años y anda en cinco que salí de mi casa y no tengo más de un hijo varón que me suceda [...] no tengo ya edad para andar por mesones, sino para recogerme y aclarar mis cuentas con Dios...

La triste situación de este hombre en estos años finales la pinta una anécdota que cuenta Voltaire:

Un día Cortés, no pudiendo tener audiencia del emperador, se abrió camino por entre la multitud que rodeaba la carroza del monarca, y subió al estribo: y que preguntando Carlos V: “qquién era aquel hombre?”, Cortés replicó: “El que os ha dado más reinos que ciudades os dejaron vuestros padres".

Pocos años después, agobiado por las deudas y la tristeza, empeñó sus bienes más valiosos y se refugió en la casa de un amigo en Castilleja de la Cuesta, cerca de Sevilla. Muy enfermo y extenuado por la disentería, el conquistador de México, 
Hernán Cortés, murió el 2 diciembre de 1547, cuando apenas contaba 62 años. El franciscano fray Toribio Motolinía, dijo de él: "Creo que es hijo de salvación y que tiene mayor corona que otros que lo menosprecian".

Me parece que una de las pocas cosas en que hemos progresado los humanos es en la estatura. Cuando en un museo de Caracas vi la cama de Bolívar pregunté si era de Bolívar niño, y resultó que era de Bolívar mayor: era como las de los niños de hoy.

De Cortés dice López de Gómara que era de buena estatura, y creo que lo decía refiriéndose a las tallas de aquella época, que tengo la impresión de que eran más bajas que las actuales. En uno de los capítulos finales de mi libro sobre Cortés me refiero a los pormenores de sus huesos que se conservan en la Iglesia de Jesús. Ahí no menciono el siguiente dato que sólo pude conocer después de publicado mi libro: el estudio de Eusebio Dávalos Hurtado sobre “Los restos de Hernán Cortés”, que publicó la Academia Nacional de Ciencias en el tomo 57, números 3 y 4, en México, 1955. Después de un estudio cuidadoso de los huesos de don Hernán el doctor Dávalos Hurtado afirma que la talla del Conquistador era de $1.58 \mathrm{~m}$., es decir, que para nuestras ideas modernas era chaparrito y su peso debió ser como el de una muchacha de hoy: entre 50 y 55 kilogramos. $^{2}$

Versión al 16 de diciembre de 2005
(1)

\section{Algunas respuestas en el juicio secreto}

[Infinitas mujeres]

XXXIX.- Al primer capítulo dijo que lo que este testigo sabe es que le vía al dicho don Fernando oír misa muy devotamente, de rodillas, e esto cada día, pero que otras cosas tenía más de gentílico que de buen cristiano especialmente que tenía infinitas mujeres dentro en su casa, de la tierra e otras de Castilla, e que segund era publica voz e fama entre sus criados e servidores, se decía con cuantas en su casa había tenía acceso, aunque fuesen parientas una de otras, que no lo fuesen, e que muy notorio se ha dicho que con primas e con hermanas, e que a este testigo le dijo una mujer, cuyo nombre aquí no se expresa: o do al diablo este hombre, qué bellaco es, que habiendo tenido a mi hija públicamente en Cuba, yendo yo a negociar con él me tomó e se echó conmigo; e que ansí mismo ha sido muy público en este pueblo e fuera dél que se echó con dos o tres hermanas hijas de Motunzuma, e que este testigo vido que tenía una hija de Motunzuma, que se llamaba Doña Ana, por amiga, e que teniéndola, este testigo vido questaba allí otra prima de la misma Doña Ana, preñada del dicho don Fernando, e que a éstas las mataron los indios al tiempo que salieron huyendo los cristianos desta cibdad, con los cuales este testigo saliendo huyendo ansí mismo, e que con otras mujeres

\footnotetext{
2 J.L. Martínez. Hernán Cortés. México, FCE-UNAM, 1990, 1012 pp. Anexos: 4 Volúmenes, Documentos Cortesianos. México, FCE-UNAM, 1990.
} 


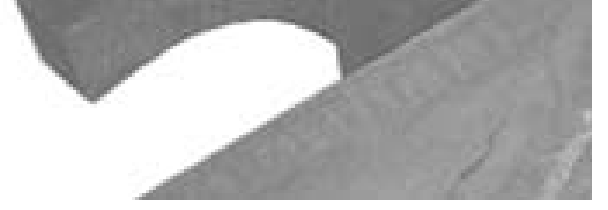

casadas es notorio que ha tenido muchos accesos e que enviaba los maridos fuera desta cibdad por que dar con ellas, los nombres de las cuales aquí no se ponen, sacáronse en un papel aparte, e que algunas dellas parieron del dicho Don Fernando; e ansí mismo dijo este testigo que vido facer al dicho Hernando Cortés muchos agravios en que parece no ser hombre temeroso de Dios, ansí como los que ha expresado arriba en muertes de indios como de españoles que vido que hizo ahorcar e afrentar por cosas livianas, especialmente a Juan Escudero e a Diego Cermeño, que los ahorcó, porque como el dicho don Fernando se alzó contra Diego Velázquez que le había enviado a estas partes, e porquestos dos eran criados de Diego Velázquez e se quisieron ir a su señor en un bergantín, por esto, los ahorcó e corto un pie a Gonzalo de Umbría por lo mismo e a un Villafaña hizo ahorcar e a otras personas que no se acuerda.

\section{(2)}

\section{[Grandísimo tesoro]}

LII.- A los catorce capítulos dijo que ansí, que al tiempo que salieron huyendo de la cibdad de Temistitan, el dicho don Fernando hizo cargar en una yegua morcilla mucho oro e con ella un paje suyo de cámara que tenia cargo de oro suyo e joyas, e que ansí mismo el dicho don Fernando hizo sacar allí mucho oro, otro que decia que era del rey del común, e queste testigo estaba presente cuando el dicho Cortés dijo a todos los oficiales de su Majestad, e que allí se entregó a personas para que lo salvasen e se hizo memorial dello por el secretario del dicho don Fernando, e después de salidos de la dicha cibdad no apareció la dicha yegua cargada de oro ni el paje de cámara que con ella iba ni las personas que lo llevaron a cargo, e como el dicho Cortés vido que la yegua e el oro era perdido, echó fama que aquel oro que se perdió era lo de su Majestad e lo otro que se había salvado, que fueron cuarenta e cinco mil pesos o más, dijo que era lo suyo, e para salir con su intinción fizo cierta probanza que aquello era lo suyo e no de Su Majestad, e ansí quedó con el dicho oro sin dar parte a Su Majestad; e que después este testigo dijo como oficial al dicho don Fernando que quintasen aquello que se había salvado e diesen parte a Su Majestad dello e que no diese lugar a que se publicase quel oro de su Majestad que era perdido o lo suyo se salvara, por que parecería mal a quienquiera que lo oyese, e que no obstante lo suso dicho, el dicho don Fernando no quiso que se quintase ni se quintó ni se dio a Su Majestad parte, puesto queste testigo como oficial de Su Majestad, había visto por sus libros que no podía tener el dicho don Fernando tanto oro como aquello que a la sazón decía quera suyo, e que sobre el mismo caso este testigo, por mandado del dicho don Fernando Cortés, dijo su dicho en la provanza que hizo sobre este caso e por que la probanza que se facía era en favor del dicho don Fernando, puesto queste testigo e otros decían la verdad de lo que pasaba, 
los escribanos que a la sazón entendían en la dicha probanza, queran Jerónimo de Alanís e Hortigosa, no ponían ni querían poner, salvo lo que cumplía al dicho don Fernando e questa es la verdad, so cargo del juramento que tiene fecho.

(3)

Declaración complementaria: Cortés se echó con dos hijas de Moctezuma

Juró en 15 de abril de 1529

El dicho Bernaldino Vázquez de Tapia, habiendo jurado e siendo preguntado qué es lo que sabe para averiguar si el dicho don Fernando se echó con dos hermanas fijas de Motunzuma, ques público e notorio que cuando el dicho don Fernando Cortés entró en esta cibdad, Motunzuma luego le dio una su hija para que tuviese por mujer o manceba, e quel dicho don Fernando Cortés la hizo tornar cristiana e le puso nombre Doña Ana e que la ternía ocho meses poco más o menos e que públicamente se decía que se echaba con ella, e que la mataron a la salida desta cibdad, cuando se levantaron los indios; e que después este testigo supo de cómo Alonso de Grado se había casado con otra hija de Motunzuma, que se llamaba Doña Isabel, e que el tiempo que el dicho don Alonso de Grado falleció, el dicho don Fernando la llevó a su casa e la tuvo ella cierto tiempo hasta tanto que la casó con Pedro Gallego, e que después de casada el dicho don Pedro oyó decir que parió desde en cinco o seis meses, e que se dijo públicamente questaba preñada del dicho don Fernando, por manera que se tiene sospecha e ansí este testigo cree segud e por razón de lo que ha dicho e de lo que oyó decir. Es de creer e cree que se echó con ambas hermanas e que verdad que ambas a dos eran hijas del dicho Motunzuma, por queste testigo oyó decir al dicho Motunzuma que la dicha doña Ana era su hija e la dicha doña Isabel se tiene por su hija, e en tal posición es habida e tenida, e que si no fuera su hija cree este testigo quel dicho Alonso de Grado no se casara con la dicho Doña Isabel, e que ésta es la verdad de lo que se sabe para el juramento que fizo e firmólo.

Sumario de la Residencia, t. II, pp. 244-245 
LA HUELCADE CARAREA

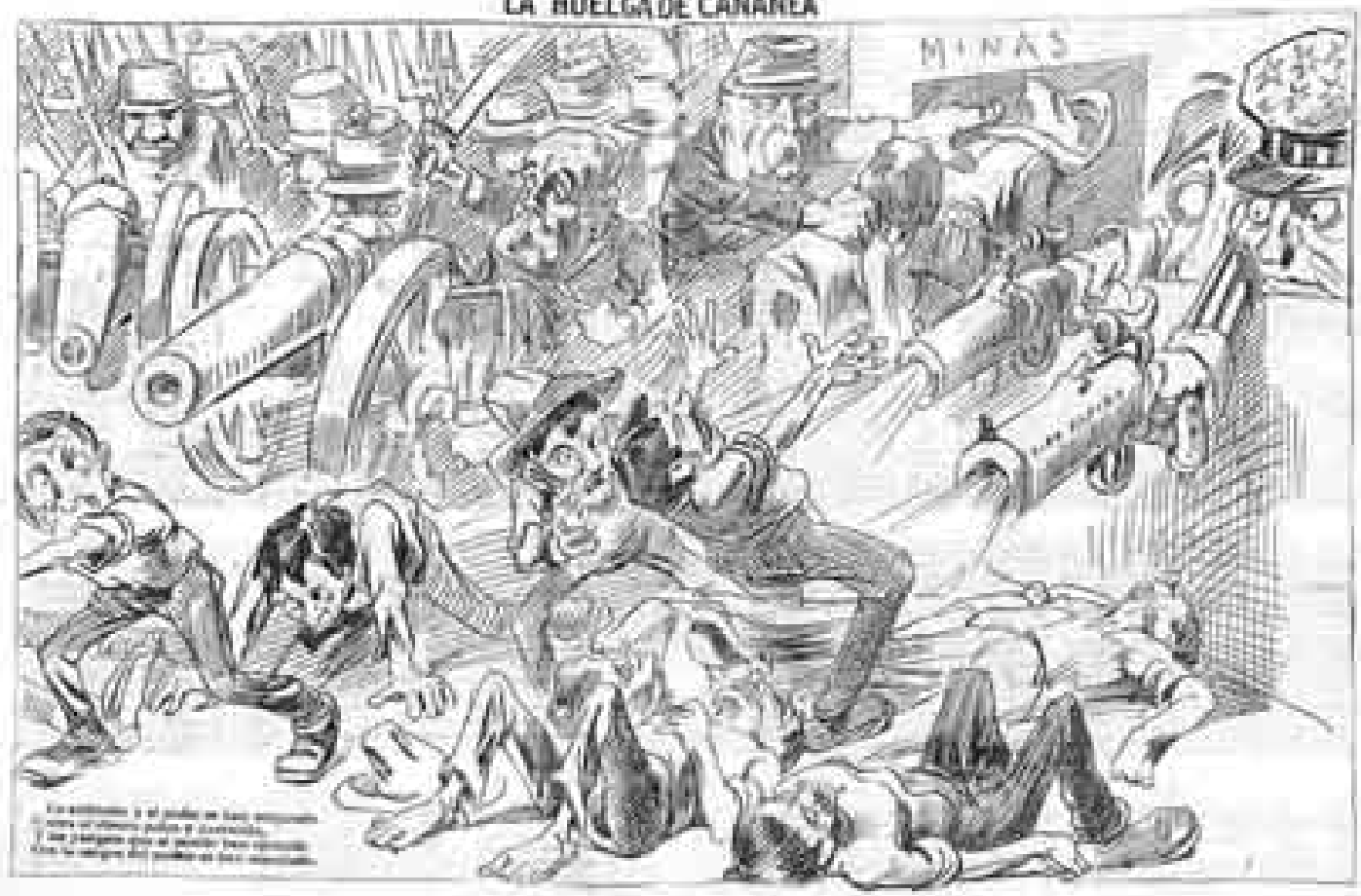

Cartón en la página central, cañoneros contra huelguistas.

El Colmillo Público, México, 17 de junio de 1906 


\title{
El Colmillo Público
}

\author{
- Luis Tamayo
}

$\mathrm{E}$ I día 1 de julio de 2006 se cumplirá el centenario de la clausura, por parte del gobierno de Porfirio Díaz, de El Colmillo Público (1903-1906), un "semanario de caricaturas" dirigido por Jesús Martínez Carrión (1860-1906) y editado por Federico Pérez Fernández (18751965), dos colaboradores de Ricardo Flores Magón.

La consigna de este periódico era:

Semanario de poder,

que espantará a los espantos,

escrito por unos cuantos

que no tienen que comer.

Los que quieran padecer

punzadas y escalosfríos (sic)

compren sin andar en líos

este periódico luego

que busca a sangre y a fuego

amores y desafíos. ${ }^{1}$

El semanario no era diferente a algunos otros que circulaban en aquel entonces en la capital de la República, salvo por su crítica agria y constante contra el supremo gobierno. Poseía también un carácter escatológico y festivo que aligeraba su lectura y que se constituyó en su éxito al brindarle numerosos lectores.

Tanto el director como el editor de este semanario habían formado parte de El hijo del ahuizote, ${ }^{2}$ fundado en 1885 por Daniel Cabrera (18581914) y Manuel Pérez Bibbins, entre otros. ${ }^{3}$ El editor -que también se permitía escribir artículos bajo el seudónimo de "El terrible Pérez"- había sido encarcelado del 15 de septiembre de 1902 a febrero de 1903, junto con Ricardo y Enrique Flores Magón, cuando la policía irrumpió en las instalaciones de El hijo del ahuizote. Aunque Juan Sarabia asumió la dirección del semanario y Ricardo Flores Magón volvió a colaborar en él tan pronto salió de prisión, esa época de la publicación no sobrevivió sino hasta mayo de 1903, cuando ya no se distribuye el número 850 y se le substituye por un único número (aunque se editaron dos) del ahora olvidado El padre del ahuizote.

\footnotetext{
1 Tomado del afiche propagandístico previo al primer número. Septiembre de 1903.

${ }^{2}$ El hijo del ahuizote (1885-1903) tenía como lema: "Semanario político y de caricaturas: Semanario feroz, aunque de nobles instintos, político y sin subvención como su padre, matrero y calavera".

${ }^{3}$ Diccionario Porrúa de Historia, Biografía y Geografía de México. México, Porrúa, 1964, p. 242.
}

- Profesor del Posgrado en Filosofía, Centro de Investigación y Docencia en Humanidades del Estado de Morelos 
El Colmillo Público es considerado por varios autores ${ }^{4}$ como el sucesor de $E l$ hijo del ahuizote en lo referente a la crítica despiadada al régimen de Porfirio Díaz y a la sociedad de su tiempo.

Como indicó Rafael Barajas “el Fisgón”, en su ensayo "Elogio y vituperio de la caricatura": “La Revolución mexicana y la Constitución de 1917 no habrían sido posibles sin la aportación programática y teórica de todos estos intelectuales que tuvieron en la prensa de caricaturas - desde La Orquesta hasta El hijo del ahuizote y El Colmillo Público- un medio privilegiado para la época". ${ }^{5}$

No podemos sino estar de acuerdo con Barajas: la caricatura y el cartón político constituyen un medio privilegiado para transmitir, de manera directa, las verdades ${ }^{6}$ de la política y los políticos.

Aunque el humor y la risa nacieron con la humanidad, como señaló Aristóteles, la caricatura política es mucho más joven -algunos autores la sitúan apenas en la Italia del siglo XVI, donde el vocablo caricare (recargar, exagerar) era utilizado para nombrar a esas críticas políticas ilustradas $-{ }^{7}$ y asentó sus fueros en nuestro país particularmente en la época prerrevolucionaria.
Al respecto, indica Boris Berenzon, en su estudio El discurso del humor en los gobiernos "revolucionarios" (1929-2000): “Si la historieta mexicana tiene su origen en las hojas ilustradas de romances y corridos, rezos, oraciones o simples avisos, los antecedentes periodísticos de nuestro cómic hay que buscarlos en la prensa política decimonónica y su poderosa gráfica satírica". ${ }^{8}$

Dicho humor político no desmiente, según Berenzon, a las tesis freudianas:" "El humor político enfrenta las situaciones que molestan a la sociedad descubriendo la verdad e iluminando el juego oculto [...] El chiste es la manifestación más importante del humor político, es tendencioso e intencional, es hostil y puede ser obsceno porque está destinado a mostrarnos una desnudez [...] busca desnudar a los políticos para despojarlos de su presunta superioridad [...] Así como el sexo es reprimido y forzado al espacio de las normas sociales aceptadas, el conocimiento de la política es ocultado a la percepción comunitaria, forzando a la gente a aceptar las decisiones de los políticos". ${ }^{10}$

Y Berenzon concluye: “El humor político es un acto de transgresión que mina los rituales, símbolos

\footnotetext{
${ }^{4}$ Entre otros: J.M. Aurrecoechea y A. Bartra. Puros cuentos. México, CNCA-MNCP-Grijalbo, 1988, p. 46.

${ }^{5}$ La Jornada Semanal. 1 de agosto de 1999.

${ }^{6} \mathrm{O}$, más bien, medio-verdades, pues como nos ha enseñado Lacan, la verdad no puede ser dicha toda.

${ }^{7}$ R. Barajas, op. cit., 1 de agosto de 1999.

${ }^{8}$ Tesis presentada para obtener el grado de Doctor en Historia, FFyL, UNAM, 2001, p. 155.

${ }^{9}$ El chiste, así como el sueño, señaló Freud, es una de las vías regias de acceso al inconciente, aunque no todos pueden percatarse de ello: "No todos los hombres son capaces de la actitud humorística; es un don precioso y raro, muchos son hasta incapaces de gozar del placer humorístico que se les ofrece", en S. Freud, "El humor" (1927), en Obras completas. Tomo XXI. Buenos Aires, Amorrortu, 1976, p. 162.

${ }^{10}$ B. Berenzon, op. cit., p. 202 y 222.
} 
y valores políticos. Más aún, es un instrumento para vengarse de los políticos [...] los chistes son un medio por el cual se les envían mensajes a los políticos sobre aquellas cosas de ellos mismos, o de su actividad, que molestan a la sociedad. Ese mensaje está orientado a la corrección y, a veces, a desestabilizar al gobierno". ${ }^{11}$

\section{El final de El Colmillo Público}

En los años que existió El Colmillo Público fue ejemplo de libertad de expresión y, gracias al carácter itinerante de la imprenta que utilizaban una vieja y pesada Gestetner- y a la ineficiencia de los servicios de inteligencia de la policía del gobierno de Díaz, pudo sobrevivir hasta 1906. Se puede corroborar que desde los inicios de ese año $E l$ Colmillo era ya, abiertamente, un colaborador de Regeneración, el órgano oficial del Partido Liberal y, por tal razón, desarrolló su programa partidista en diversas entregas; ${ }^{12}$ asimismo, exhortaba a la rebelión contra el régimen de Díaz. ${ }^{13}$ En la columna “Despertemos" del 7 de enero de 1906 leemos, bajo la firma de Anakreón: ${ }^{4}$ "Sin rumbo fijo, como embarcación que ha perdido la brújula bajo un cielo negro, así marchan nuestras clases proletarias sin ver en el horizonte hostil un puerto salvador hacia el cual dirigir su barco, juguete de los fuertes y los audaces. ¡Al trabajo! ¡Al trabajo! Eso es lo único que en su prolongada noche oyen nuestros menesterales; pero en sus oídos fatigados por el estruendo de las máquinas no resuena una voz de consuelo y esperanza. Apenas, de tarde en tarde, los pontífices del servilismo que borrajean periódicos sostenidos por la Dictadura para envilecer a las masas cantan como las sirenas para halagar la vanidad de los obreros y hacerles olvidar los sueños de redención $[\ldots] " .{ }^{15}$

En sus páginas la Dictadura de Díaz es golpeada salvaje y continuamente. En el artículo "Sangre vieja” escribe Anakreón: “Inútil es andar buscando el origen de nuestro atraso político y social, cuando es tan fácil encontrarlo: manos temblorosas son las que manejan las riendas del gobierno. Viejo es el presidente, viejos los ministros, viejos los gobernadores [...] A estos hombres viejos debemos nuestro atraso. Aferrados a la tradición; por lo general faná-

\footnotetext{
${ }^{11}$ Ibid., p. 419.

${ }^{12}$ Así se lee el 4 de marzo de 1906 en el artículo "El programa del partido liberal": “Liberales por convicción que somos, y no por conveniencia, no hemos vacilado en prestar nuestro apoyo a la idea de organizar el Partido Liberal [...] iniciado por los liberales desterrados que residen en St. Louis Missouri” (p. 127). El 11 de marzo y el 10 de junio de 1906 se continúa la reflexión respecto a dicho programa.

13 "Despertemos al gigante" se denomina el artículo firmado por Anakreón el 4 de febrero de 1906; "Parias: ¡luchad!” el del 6 de mayo del mismo año.

${ }^{14}$ Varios indicios permiten suponer la pluma, bajo el nombre del poeta lírico griego del siglo VI-V a.C., de alguno de los hermanos Flores Magón.

157 de enero de 1906, p. 6.
} 


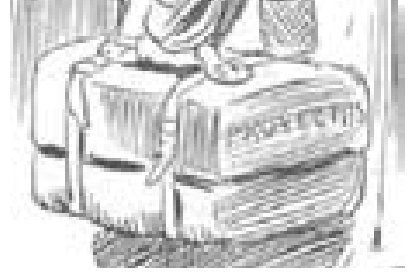

ticos; uno que otro intelectual rezagado entre ellos; casi todos ignorantes en grado máximo, no pueden imprimir a sus actos el carácter fresco, sano y vigoroso que distingue a los actos de los jóvenes". ${ }^{16}$

En el titulado "La verdad triunfa al fin” continúa: “El servilismo está empeñado en que consideremos al Gral. Díaz como un ser de naturaleza distinta de la nuestra, barro vil, lodo animado, que está muy lejos de parecerse a la divina substancia de nuestro dictador [...] Mas los hombres que pensamos con la cabeza y que prohibimos al estómago toda ingerencia (sic) en nuestras decisiones no vemos en Don Porfirio sino al hombre común y corriente que por un capricho de la fortuna se nos ha impuesto". ${ }^{17}$

En El Colmillo también se dio oportuna noticia de los acontecimientos de Cananea y Río Blanco.

La entrega del 17 de junio de 1906 presenta un cartón de Martínez Carrión donde Rafael Izábal, el Gobernador de Sonora, y el Tío Sam pisotean a los mineros de Cananea y donde se lee al calce:

¡Oh pueblo! ¿Qué te resta cuando has sido por los rurales yanquis pisoteado, por las fuerzas mexicanas oprimido y por patrones yanquis fusilado? ¡Oh pueblo! Tu valer está perdido ni el derecho a vivir has conservado!
Otro cartón presenta un grupo de cañoneros, comandados por militares mexicanos y estadounidenses, que abren fuego contra los huelguistas de Cananea.

Otro más se burla del patriotismo de Rafael Izábal, a quien la prensa gobiernista había justificado por su acción contra los mineros: "Y dice 'El Imparcial’ y 'El Mundo' con seriedad pasmosa: 'Cananea se ha salvado gracias al valor, al patriotismo y a la energía del gobernador Izábal; no hubo violación de territorio y fueron particulares norte-americanos los trescientos y tantos que acompañaban a Izábal desde Naco y la mejor prueba era que vestían de paisanos y en que regresaron a su tierra cuando el Gobernador se los indicó'”. ${ }^{18}$

Ahora sabemos que tanto El Imparcial como El Mundo eran los que mentían. Ciertamente hubo el ingreso al país de algunos mercenarios americanos contratados por Green, el coronel norteamericano y gerente de la Cananea Consolidated Copper Co., los cuales no eran soldados del ejército de los USA, pero, tal como indica el informe de Associated Press fechado en Douglas, Arizona, el 2 de junio de 1906: “El Gobernador Izábal del Estado de Sonora llegó a Naco a las 7:30 de esta mañana, e inmediatamente dio orden permitiendo que el ejército americano que se encontraba en Bisbee, Douglas, y otros

\footnotetext{
${ }^{16} 25$ de febrero de 1906, p. 111.

173 de junio de 1906, p. 343.

181 de julio de 1906, p. 406.
} 
puntos de Arizona lo acompañasen a Cananea. Los americanos organizados por el capitán Tom Rynning formando una compañía de rurales llegaron con el Gobernador en un tren especial a las 8:30 a Cananea. Iban 450 hombres de fuerza". ${ }^{19}$

En El Colmillo sabían bien que la prensa gobiernista mentía y por tal razón en el cartón titulado “Labor insana"20 de Martínez Carrión aparecen tanto Porfirio Díaz como el cónsul de los United States of America, dando un baño a Izábal con jabones y cepillos que llevaban los nombres de los periódicos gobiernistas: El imparcial y El mundo.

Más adelante, abunda Anakreón sobre los hechos de Cananea en el artículo "Se nos ha humillado": "Uno de los hechos más escandalosos ocurridos en Sonora durante la huelga de los mineros de Cananea, fue la intervención de las tropas americanas [...] que se debió a la súplica que hizo el gobernador Rafael Izábal a las autoridades de los Estados Unidos para que les prestaran fuerzas con que apaciguar la huelga que llegó a alcanzar serias proporciones [...] La invasión de esas tropas extranjeras constituye un ultraje a la dignidad de la Nación, y dejar impune el delito equivale a sentar un precedente funesto que será en lo futuro una fuente de peligros para la independencia de la República”. ${ }^{21}$
La historia ha revelado a Anakreón como un visionario; en la actualidad los United States of America de baby Bush se erigen en policías del mundo e impunemente intervienen donde les place, no sólo en nuestra nación. Desgraciadamente la voz de ese Anakreón no pudo ser escuchada.

Como puede adivinarse, la postura política de El Colmillo se convirtió rápidamente en razón de persecución y clausura. Después del ejemplar antes citado sólo sobrevivió un número más. En el “Alcance al número 147” del 1 de julio de 1906 leemos: “¡Vaya una difícil situación la nuestra! Nos regocijaríamos con empapar nuestras plumas en veneno y sin embargo de eso tenemos que escribir con la mansedumbre del cordero. Debían ser nuestras cuartillas vómitos de lumbre que incineraran. [...] El Colmillo Público se suspenderá temporalmente $[. .$.$] . Se ha inventado un delito ridículo a los$ Sres. Martínez Carrión y Pérez Fernández; se les acusa de rebelión; un Juez, que no es bueno, pretende que sobre las conciencias inmaculadas del Director y del Administrador de El Colmillo Público, caiga la mancha de trastornadores del Orden Público, cuando los dos son amigos de la libertad y del orden; cuando los dos adoran a un gobierno con tal que ese gobierno sea justo". ${ }^{22}$

\footnotetext{
${ }^{19}$ Citado por El Colmillo Público el 3 de junio de 1906, p. 363.

201 de julio de 1906, pp. 404-405.

2117 de junio de 1906, p. 374.

221 de julio de 1906.
} 
Así termina la historia del semanario pues la suspensión no fue sólo temporal sino, desgraciadamente, definitiva.

Mas la intención de este ensayo no es sólo referir la historia de El Colmillo o la de la caricatura en México, ya revisada por valiosos investigadores, ${ }^{23}$ sino de la peculiar gesta de su editor y articulista Federico Pérez Fernández.

\section{... y se fue hecho la cochinilla}

Corría el año 1906. El Colmillo Público había publicado, como antes señalamos, varias notas relativas a los desórdenes de Cananea y Río Blanco, atacando fuertemente al gobierno y ridiculizando al entonces primer mandatario Porfirio Díaz. La consecuencia no se dejó esperar. Tropas gubernamentales localizaron y allanaron las instalaciones del semanario, destruyeron todo lo que pudieron y arrestaron a los principales responsables: Martínez Carrión y Pérez Fernández. Los llevaron primero a la cárcel de Belén, y al segundo, posteriormente, a la entonces temible cárcel de San Juan de Ulúa, sita en las cercanías del Puerto de Veracruz, ésa donde algunos presos eran torturados en celdas donde el goteo constante les atravesaba el cráneo.

Martínez Carrión no soportó la experiencia, murió en Belén luego de haber contraído el tifo. ${ }^{24}$ Pérez Fernández, más joven, corrió con mejor suerte. Luego de soportar el impacto inicial se acomodó poco a poco al internado obligatorio. Posteriormente su carácter letrado se constituyó en su salvación. Los carceleros, cuya inteligencia no era precisamente notoria como se apreciará a continuación, lo encontraron útil y le confiaron la tarea de llevar la lista de los presos, tarea que a ellos, por ser en su enorme mayoría analfabetos, se les dificultaba enormemente.

Así transcurrieron los meses, los años.

Y poco antes de iniciarse la después denominada "Revolución mexicana" ocurrió un evento peculiar que me permitiré narrar con detalle. ${ }^{25}$

Dado que en aquellos años la Fortaleza de San Juan de Ulúa no se encontraba, como ocurre en la actualidad, integrada al Puerto de Veracruz sino que, no obstante su cercanía, se mantenía a una distancia no despreciable, ocurrió que, en una ocasión, arribó al puerto de la prisión un barco de

\footnotetext{
${ }^{23}$ En (además de los ya citados) S. Pruneda. La caricatura como arma política. México, INEHRM, 1958; C. Monsiváis. “Impresiones sobre la cultura urbana en México”, en Cuadernos comunicación. Núm. 22. México, abril de 1977; A. Bartra. Regeneración 1900-1918. La corriente más radical de la Revolución Mexicana a través de su periódico de combate. México, 1977; E. del Río. Un siglo de caricatura en México. México, Grijalbo, 1984; R. Barajas. Historia de un país de caricatura. México, Fonca, 1999.

${ }^{24}$ Diccionario Porrúa de Historia..., op. cit., p. 957.

${ }^{25}$ Agradezco a la doctora Consuelo Pérez viuda de Tamayo, hija de Federico Pérez Fernández, la comunicación de la historia.
} 
bandera norteamericana. Estaban perdidos. Sabían que el puerto de Veracruz se encontraba muy cerca, pero no sabían si estaba al norte o al sur. $Y$ acercaron un bote a la fortaleza para resolver la cuestión preguntando a los vigilantes de la misma. Pero ello no era sencillo, ni los unos hablaban español, ni los otros inglés. Sin embargo, como -vox dixit- los mexicanos somos esencialmente corteses o, quizás porque esos hombres rudos no querían cometer un error con los enviados de esa potencia aliada, decidieron ayudar a los norteamericanos. Pero para ello necesitaban saber lo que querían. En ese predicamento lo único que acertaron idear fue... ¡traer a Pérez Fernández! Si sabía leer y escribir... ¡también podía saber inglés! Prontamente lo sacaron de su celda y lo llevaron al puerto de la prisión. Ahí le solicitaron que les informase acerca de lo que deseaban los norteamericanos. Y Pérez Fernández, el cual, por cierto, estaba muy poco versado en la lengua de Shakespeare, les respondió: “Quieren que suba al barco a hablar con el capitán".

Los carceleros obedecieron. La orden de un capitán era incuestionable, máxime si se trataba del de una nación aliada. Acto seguido Pérez Fernán- dez subió al bote con los norteamericanos y éstos lo condujeron al barco.

Los carceleros nada pudieron hacer cuando notaron que el barco americano levaba anclas y retomaba su camino alejándose de la prisión. Pérez Fernández, una vez en la embarcación, se había hecho entender a señas con el capitán y le había indicado el camino al Puerto de Veracruz. Los marinos norteamericanos nunca sospecharon que ese hombre vestido de manera tan curiosa (no sabían que tal era la vestimenta de la cárcel) pudiese ser un preso, quizás tomaron la presencia de ese orientador como una muestra de la, ya entonces famosa, hospitalidad mexicana.

Tan pronto arribó el buque a puerto, Pérez Fernández se despidió de sus agradecidos e involuntarios liberadores y se perdió entre el gentío. La historia narra que volvió con muchas dificultades a la capital. Debió tardar más de dos meses para volver a sus lares pues no confiaba de los caminos reales y era forzado a esconderse al primer signo sospechoso.

Son curiosas las enseñanzas que otorga el humor de un "semanario de caricaturas". En ocasiones nos permiten actuar como personajes de caricatura y en tanto tales, vencer obstáculos inimaginables. ${ }^{26}$

${ }^{26}$ S. Freud, en su gesta personal, tampoco se abstuvo del uso del humor. B. Berenzon (op. cit., p. 3) nos recuerda que cuando Freud fue constreñido a abandonar Viena en 1936 a causa de la ocupación nazi fue, bajo coacción, obligado a firmar una declaración en la cual reconocía que los funcionarios del partido nazi lo habían tratado correctamente. Luego de hacerlo Freud se permitió añadir, de su puño y letra, "puedo recomendar cordialmente la GESTAPO a todos". 


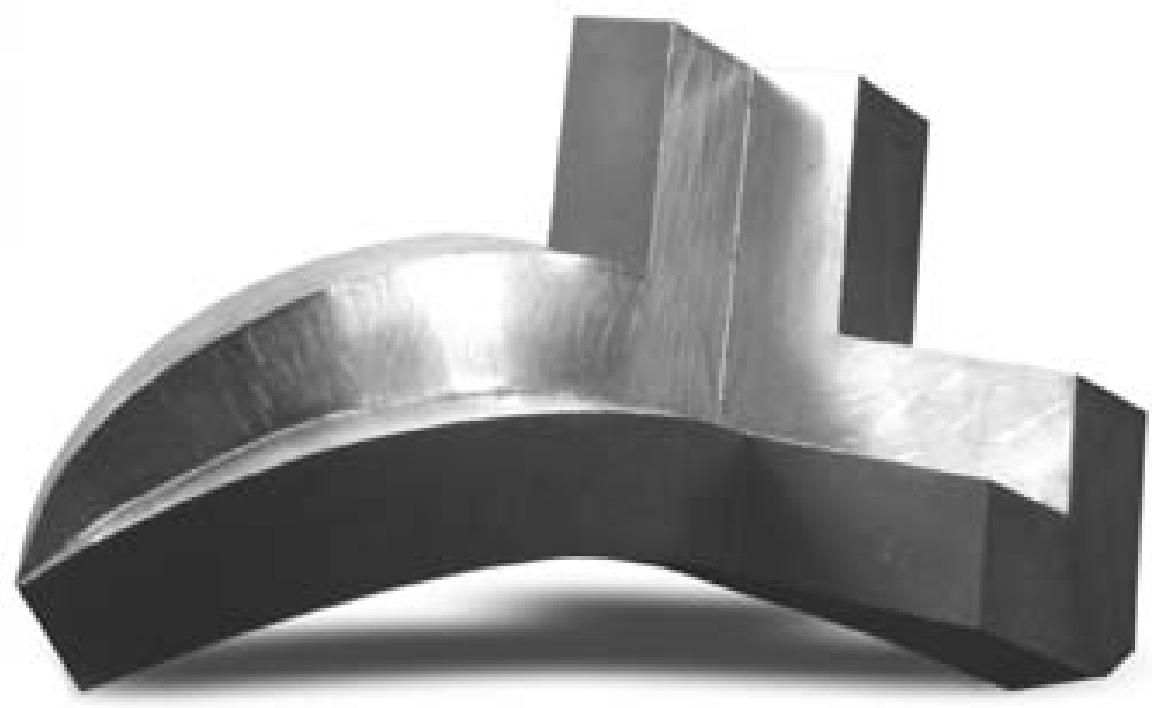

Fulcrum, 1994 


\section{Manuscritos del Fondo Reservado de la Biblioteca Nacional}

- Silvia Salgado

$\mathrm{E}$ l origen de la Biblioteca Nacional de México se remonta al siglo XIX. Después de la Guerra de Independencia del dominio español (1810-1821), los gobiernos de la República emitieron cuatro decretos presidenciales que intentaron fundar la institución. Sin embargo, hasta 1867, Benito Juárez expidió el mandato definitivo de su creación, donde estableció que la sede fuera el antiguo Templo de San Agustín, en la Ciudad de México, y se nombró como director a José María Lafragua. Desde entonces, todos los pasos se dirigieron a preparar el lugar, así como a recoger y ordenar el material bibliográfico. El caudal manuscrito e impreso primigenio que ahora recibe el nombre de "Fondo de Origen", y que se acerca a los cien mil volúmenes, se obtuvo principalmente por las leyes de supresión y desamortización de los bienes de la Iglesia Católica, así como de la Real y Pontificia Universidad de México.

En 1880, José María Vigil asumió la dirección de la Biblioteca y emprendió su organización técnica con base en el sistema belga de clasificación de Namur. El 2 de abril de 1884 se inauguró oficialmente la institución, y hasta 1909, periodo que duró su gestión, la gente de la Biblioteca se inició en una tarea similar a la de Sísifo, es decir, la de sacar de sus cajas los miles de volúmenes expropiados, y proceder a su clasificación, catalogación y colocación en los estantes. La primera idea de organización bibliográfica que prevaleció y que a la fecha continúa es la de ordenar por temas, con la excepción de los manuscritos, que difieren de los impresos, por ser obras únicas, y en muchos casos compuestas por varias materias en un mismo volumen. ${ }^{1}$

Del tiempo de la fundación de la Biblioteca se tiene uno de los primeros testimonios relativo a los libros manuscritos que refleja la mentalidad liberal y decimonónica dominante, frente al mundo y a los objetos coloniales de orden eclesiástico, que en aquel momento la República intentaba abolir. Me refiero a la compra-venta de ocho "salmos

${ }^{1}$ L. González. La Biblioteca Nacional de México. México, BNM, 1910. Rafael Carrasco. Historia de la Biblioteca Nacional de México. México, SER, 1948. J.B. Iguiniz. "La Biblioteca Nacional de México", en Boletín de la Biblioteca Nacional de México. T. I, núm. 1, enero-marzo 1950. M. Alcalá. "La Biblioteca Nacional”, en Boletín de la Biblioteca Nacional de México. T. VIII, núm. 1, enero-marzo 1957. E. de la Torre. "Palabras del director...", en Boletín del Instituto de Investigaciones Bibliográficas. T. I, núm. 2, julio-diciembre 1967. I. Osrio, et al. "Monografía de la Biblioteca Nacional”, en Boletín del Instituto de Investigaciones Bibliográficas. Núm. 7, 1995. S. Salgado. "El Catálogo del Fondo Reservado de la Biblioteca Nacional”, en Gaceta bibliográfica. Año1, núm. 3, mayo-junio 1996. México, UNAM, Instituto de Investigaciones Bibliográficas.

- Instituto de Investigaciones Bibliográficas. Especialista en el Fondo Reservado de la Biblioteca Nacional-UNAM 


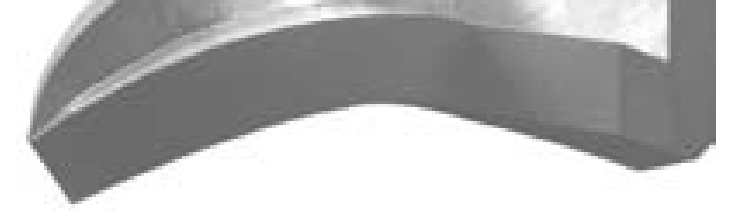

gregorianos" o libros de coro manuscritos e iluminados, a cambio de veinticinco libros ingleses impresos y “modernos”, entre el señor Thomas Unett Bucklehurst, particular inglés, y la Biblioteca Nacional. Con esa transacción se pretendió cambiar el viejo acervo colonial, por las obras positivas de orden y progreso que ofreció el británico. Hay que destacar que este evento ilustra claramente la diferencia ideológica y cultural de concepciones sucesivas, entre lo moderno, lo contemporáneo y lo globalizado, ya que desde la segunda mitad del siglo XX no es posible vender obra alguna de la Biblioteca, porque es considerada como parte del patrimonio nacional, con miras a ser patrimonio de la humanidad. ${ }^{2}$

De aquella primera época es también el hallazgo de algunos manuscritos franciscanos. Es el caso del llamado Cantares mexicanos. Hermosísimo códice del siglo $\mathrm{XVI}$, que reúne elementos indígenas e hispanos de primera fuente. Su soporte es en papel de trapo, y está formado por cuadernos cosidos a la usanza europea; pero combina escritura pictográfica mexicana a la acuarela, con textos latinos y nahuas. El contenido de los Cantares es el de una miscelánea de trabajos disímiles en los que destacan veinte himnos sagrados de los antiguos mexicanos, las Fábulas de Esopo escritas en náhuatl, así como un extraordinario calendario adivinatorio o Tonalamat, con las fiestas solemnes de los meses, los días y los dioses que gobiernan cada celebración, elementos que registran las costumbres y creencias de los indígenas, en tiempos previos a la conquista hispana. Esa parte del volumen es de las más originales visualmente, ya que combina representaciones iconográficas hechas bajo convenciones plásticas mesoamericanas, pero con notable influencia europea, porque algunas figuras no ostentan sólo las formas esquemáticas o fijas características de la tradición precolombina del altiplano mexicano, sino que tienen cierto movimiento y volumen que indican ya la simbiosis de lo indígena con prácticas pictóricas europeas. Cabe apuntar que esa obra es la más estudiada de los libros manuscritos de la colección del Fondo Reservado.

En el pequeño grupo de libros manuscritos de tradición indígena e hispana que se resguardan en el Fondo Reservado de la Biblioteca Nacional de México se encuentra el Mapa de Azcapotzalco, códice pictográfico inscrito en un gran folio de papel mexicano, fechado en el siglo XVI, y trazado con una perspectiva aérea, que podría llamarse a "vuelo de pájaro", distinta a la empleada convencionalmente por los mesoamericanos, quienes incluían la dimensión del tiempo al asignar fechas a sus cartografías, así como el diseño frontal y plano de los perfiles de sus figuras. En ese mapa del pueblo de origen "tepaneca", cercano a la

\footnotetext{
${ }^{2}$ S. Salgado. Libros de coro conservados por la Biblioteca Nacional de México. Aportaciones a la iluminación de manuscritos novohispanos de los siglos XVII y XVIII. Tesis doctoral presentada y aprobada en la Universidad de Sevilla. Octubre de 2004.
} 
antigua capital de México Tenochtitlán, se observa una cuadrícula más o menos regular que incluye el centro del lugar señalado, en el que se ubicó la plaza principal, la iglesia de los dominicos, los caminos que convergían al núcleo, así como alguna figura humana. En toda la composición se distingue una mezcla de convenciones plásticas esquemáticas, propias de los modos mexicanos precolombinos, con figuras de tradición europea como son la arquitectura de la iglesia, la traza renacentista, el volumen de la figura humana y algunas glosas latinas que señalan el nombre de algunos lugares. Se le conoce porque ha sido fotografiado y publicado para ilustrar algunos eventos de interés, pero carece de catalogación y de estudios.

El padre y nahuatlato Ángel María Garibay Kintana, publicó, en el año de 1966, un importante catálogo de cinco páginas intitulado “Los manuscritos en lengua náhuatl de la Biblioteca Nacional de México", en el que registró aquellos libros y documentos escritos en caracteres latinos, que se leen en el idioma mexicano. Ésa es la primera obra de consulta especializada en las lenguas indígenas sobre los manuscritos del Fondo Reservado. No obstante, falta hacer el registro de los otros idiomas vernáculos que ahí se encuentran. ${ }^{3}$

Otro conjunto importante de libros manuscritos catalogado y estudiado en la Biblioteca Nacional de México es el que trata de las obras escritas en latín y que abundan en la colección, ya que el origen principal de ese fondo proviene de la expropiación hecha a los conventos, a la antigua Universidad y a la Catedral, en el siglo XIX. El estudio más serio sobre ese grupo se debe a los señores Jesús Yhmoff y David Castañeda, quienes unieron esfuerzos para describir bibliográficamente y publicar, en 1975, el "Catálogo de obras latinas que se conservan en la Biblioteca Nacional de México". Ése es, en definitiva, el instrumento de consulta más voluminoso que hay sobre la colección de manuscritos. Cabe advertir que tras una revisión minuciosa de aquella obra de consulta, así como de la propia colección de manuscritos, se descubre que varios libros tienen las portadas ornamentadas, y se ha encontrado que ése es el tipo de ilustración e iluminación más frecuente que se presenta en los libros y documentos manuscritos que se conservan en la Biblioteca Nacional, por lo que constituye uno de los elementos plásticos más representativos de esa colección.

En el repertorio citado de obras latinas se describe el Manuscrito 1840, uno de los códices más raros y curiosos de la Sección de Manuscritos. Se trata de un pequeño y delicado Libro de horas que se copió e iluminó al temple y con oro sobre vitela, probablemente en el siglo XV. La obra no ha sido objeto de un estudio consistente, aunque se le conoce porque es el códice más antiguo que

\footnotetext{
${ }^{3}$ Á.M. Garibay Kintana. "Los manuscritos en lengua náhuatl de la Biblioteca Nacional de México”, en Boletín de la Biblioteca Nacional de México. T. 17, núm. 1-2, enero-febrero 1966, México, pp. 15-19.
} 
conserva la Biblioteca Nacional, además de que ha sido exhibido y fotografiado en parte, para ilustrar alguna publicación. Su factura es fina y abundante en miniaturas que recrean el estilo de la escuela borgoñona de la iluminación. No tiene firmas ni fecha de confección, pero podría pensarse que ese libro llegó a la Nueva España en el bagaje de un civil, o tal vez de un soldado, en los primeros años de la conquista y la colonización de la Nueva España, ya que tiene un estilo artístico de iluminación que tuvo su mejor época en los siglos XIV y XV, pero que no repercutió más allá del Quinientos. Su estado de conservación es muy bueno.

Por otra parte, en el ámbito de las ciencias, el historiador Roberto Moreno y de los Arcos desarrolló un valioso "Catálogo de los manuscritos científicos de la Biblioteca Nacional”. No es tan extenso como el repertorio de los libros en latín, debido a que el tema no tuvo gran desarrollo en la Nueva España; sin embargo, en él se describen las obras que advierten la presencia de las nacientes academias y sociedades científicas e ilustradas novohispanas durante el siglo XVIII. ${ }^{4}$

En la Sección de Manuscritos del Fondo Reservado se conservan varios libros de texto de la Real y Pontificia Universidad de México, referentes a la enseñanza de la teología, la filosofía, la retórica, la gramática, la jurisprudencia y la medicina. Sin embargo, la mayoría de los manuscritos que se resguardan de la antigua Universidad son los libros administrativos, donde se apuntó la vida diaria de la institución, tales como los informes de los bedeles o las listas de asistencia de los alumnos y los profesores, documentos que registran nombres, actividades y frecuencias nada desdeñables para recrear lo cotidiano de aquel establecimiento. Cabe apuntar que el Archivo General de la Nación de México conserva un número importante de documentos impresos y manuscritos de la Universidad, entre los que destaca la colección de tesis novohispanas que se imprimieron y defendieron al final del siglo XVI. Dichas disertaciones constaban de un folio en el que se asentaban tres o cuatro sentencias en las que se basaba la tesis, además de los agradecimientos, las dedicatorias, las ilustraciones heráldicas, etcétera. $Y$ era costumbre que esas hojas sueltas se pegaran en determinada puerta de la Universidad, para que así se conocieran públicamente, antes del examen. ${ }^{5}$

Entre los libros manuscritos de carácter técnico o práctico, se encuentran algunos dedicados a la arquitectura, la ingeniería y a la extracción de minerales como son el azogue o el beneficio de la plata, y entre las hojas de esos informes o estudios se pueden observar algunas ilustraciones a la tinta y a la acuarela, de máquinas y procesos propios de esas actividades. No obstante, ese reducido grupo de libros y documentos no ha sido estudiado.

\footnotetext{
${ }^{4}$ R. Moreno. “Catálogo de los manuscritos científicos de la Biblioteca Nacional”, en Boletín del Instituto de Investigaciones Bibliográficas. T. I, núm. 1, enero-junio 1969, pp. [61]-103.

${ }^{5}$ Varios. Los impresos universitarios novohispanos del siglo XVI... México, UNAM, 1993.
} 
En otro tenor, hacia el año de 1977 el Centro de Lingüística Hispana de la Universidad Iberoamericana (México) dio a conocer un Índice de las obras de teatro y diálogos representables de la Sección de Manuscritos de la Biblioteca Nacional, que desarrolló un equipo amplio de universitarios, y que ha servido como guía para saber cuáles obras del arte dramático se encuentran en ese conjunto.

Pocos libros y documentos manuscritos de la colección del Fondo Reservado han sido objeto de estudio como el citado Cantares mexicanos, los Libros de coro novohispanos o el llamado Theatro de la Nueva España, escrito por Diego García Panes y Abellán, teniente coronel de infantería y capitán del Real Cuerpo de Artillería, quien lo compuso en el siglo XVIII. Esta magna obra escrita en varios volúmenes de gran formato y bellamente ilustrada a la acuarela sobre papel europeo, ha sido estudiada desde una perspectiva histórica por don Ernesto de la Torre, en buena medida por los "sucesos memorables desde que los españoles desembarcaron en Tabasco hasta la toma de Tenochtitlán”, es decir, del año 1517 al 1521, aproximadamente. La obra presenta un conjunto de cuadros a página entera que ilustran la conquista de México por el extremeño Hernán Cortés y su ejército, bajo la mirada y el pincel anónimo de un hispano o un criollo ilustrado. ${ }^{6}$

En la colección de los Manuscritos también se resguarda un conjunto de volúmenes encuadernados en pergamino, que contienen copias manuscritas e impresas de las cédulas expedidas por las casas reales e imperiales de los Austria y los Borbones, que registran los mandatos relativos al Virreinato de la Nueva España. Este grupo, conocido como el "Real Cedulario", es objeto de catalogación y estudio por el historiador Luis Olivera.

Varios libros en diferentes ocasiones, y especialmente en catálogos de exposiciones programadas por el Instituto de Investigaciones Bibliográficas, han mostrado o mencionado a los libros manuscritos e iluminados conservados en la Biblioteca Nacional de México, entre los que se pueden nombrar los siguientes: Das buch in Mexiko $=E l$ libro en México (1970), Tesoros bibliográficos que conserva la Biblioteca Nacional de México (1984), y Memoria de México y el Mundo. El Fondo Reservado de la Biblioteca Nacional de México (2001). No obstante, está por hacerse la magna tarea de identificarlos, catalogarlos, estudiarlos, conservarlos y difundirlos como colección de la Sección de Manuscritos del Fondo Reservado de la Biblioteca Nacional de México.

\footnotetext{
${ }^{6}$ D. García Panes y Abellán. Theatro de la Nueva España... Publicado por José Ignacio Echegaray, con introducción y notas de Ernesto de la Torre. México, San Ángel Ediciones, 1998.
} 
El asesinato de Elena Garro.

Periodismo a través de una perspectiva biográfica

de Patricia Rosas Lopátegui*

-Rosa Rojas**

E asesinato de Elena Garro. Periodismo a través de una perspectiva biográfica de Patricia Rosas Lopátegui es una formidable investigación que nos acerca a una de las facetas menos conocidas de la Garro: su actividad reporteril y de artículos de opinión sobre todo en revistas y en algunos periódicos del país, en Francia, España y Estados Unidos; una recopilación que se presenta además contextualizada con cierta información histórica que nos permite ubicar el momento en que estas colaboraciones fueron elaboradas y publicadas, que nos acercan a la circunstancia de la vida de la escritora, como bien lo hacen otra Elena Poniatowska en el prólogo en el que critica a la autora del libro señalando su poca objetividad al dar siempre un relato de los acontecimientos desde la perspectiva de Elena Garro y una interpretación de los mismos desde su admiración irrestricta hacia la figura y la obra de su biografiada.

Admitiendo esa falta de objetividad, podemos quizá compartir el planteamiento de la Poniatowska cuando nos dice que estos artículos de la Garro, rescatados después de minuciosas investigaciones hemerográficas por Rosas Lopátegui y sus colaboradores y colaboradoras "no añaden un centímetro" a la estatura de novelista, cuentista y autora teatral de la Garro, lo cual puede ser cierto. Sin embargo, lo que no puede negarse es que este libro, al develar otra faceta de la obra y la vida de Elena Garro, nos acerca al conocimiento de algunos de los temas que posteriormente desarrollaría en varios de sus libros, cuentos y obras de teatro. Pienso en estos momentos en "El árbol” o en algún cuento de La semana de colores, donde recoge con su singular maestría algún episodio de la vida de Antonia, la esposa de Enedino Montiel, ambos asesinados a machetazos en 1965 por su defensa de las tierras de su comunidad indígena de Ahuatepec, donde hoy se levanta la colonia Antonio Barona, aquí en las orillas de Cuernavaca.

Rosas Lopátegui nos acerca un poco más al conocimiento del alma de una mujer excepcional, a la cual, dice, un marido dominante y ególatra -Octavio Paz- buscó obstaculizar su creatividad, que en el ambiente machista de los años cuarenta y cincuenta de las capillas literarias de México, España y Francia era menospreciada y vista sólo como la esposa de Paz, y la cual, dice Rosas Lopátegui, a raíz de su activismo a finales de los cincuenta a favor de los indígenas, especialmente de los de Ahuatepec, sobre cuyos problemas escribió en el semanario Presente!, fundado en 1959 por mi

\footnotetext{
* Rosas Lopátegui, Patricia. El asesinato de Elena Garro. Periodismo a través de una perspectiva biográfica. México, UAEM - Porrúa, 2005, 480 pp, ilus.

** Texto leído en la presentación del libro el día 5 de diciembre de 2005 en la Sala de rectores de la UAEM.
}

- Periodista de La Jornada. Hija de Cristóbal Rojas Romero, fundador del semanario Presente! que se editó a partir de 1959 en Cuernavaca 
padre, Cristóbal Rojas Romero, habría sido “obligada a abandonar México por razones personales y políticas”. Las personales serían las intrigas de las “cabezas bien pensantes" en relación con presuntas relaciones extramaritales; las políticas, la censura, la presión y la represión de un gobierno que tenía cooptados a los intelectuales, lo cual es cier to para muchos, pero también es el mismo gobierno que sin embargo permitió que le fuera entregado en Premio Xavier Villaurrutia en 1963 por su novela Los recuerdos del porvenir, premio que por cierto acudió a recibir del brazo de Rojas Romero y que Elena recibió de manos del entonces secretario particular del presidente López Mateos.

“La censura se impuso y Garro se vio obligada a abandonar México y la lucha de los zapatistas morelenses”, dice Rosas Lopátegui. Hay que aclarar que la censura habrá triunfado contra Garro porque Cristóbal Rojas jamás flaqueó en esa lucha, y no fue Elena quien "le ganó" las tierras de Ahuatepec a su amigo Enedino Montiel y sus compañeros, sino la lucha incansable de todos ellos, siempre apoyados, asesorados y defendidos por Rojas Romero. Cabe decir que esas tierras que habían ganado en un juicio, las perdieron en un desacato de la justicia por la decisión de la Suprema Corte a favor de los fraccionarios que pretendías apoderarse de ellas, por lo que tomaron la decisión de invadirlas, con el secreto apoyo moral del ex presidente Lázaro Cárdenas, lo que llevó a que fueran rodeados por el ejército, a que Rojas Romero amenazara con pedir asilo en la embajada gringa si el ejército entraba a desalojarlos, al asesinato de Enedino y Antonia, al acoso de policías y agentes secretos sobre mi familia, etcétera, pero esa es otra historia.
Elena Garro, dice Lopátegui, en el ámbito periodístico abordó la problemática de género, habló de política nacional e internacional, hizo una radiografía de la cultura y del campo mexicanos y diseccionó los lastres del racismo. Garro se dice víctima de persecuciones y complots y no hay razón para dudar de que la persecución debe haber existido contra ella igual que existió contra Rojas Romero. Si temía por su vida en esos episodios de batalla contra la corrupción, el racismo, la impunidad, que se daban a través de su pluma y de las páginas todas de ese pequeño gran periódico que fue Presente!, no se puede atribuir sólo a la paranoia que muchos afirman que sufría la escritora, había razón para esos temores porque esas luchas costaron la vida de varios de los indígenas que ella ayudó a defender en Ahuatepec, así como las vidas de Rubén Jaramillo, su esposa y sus tres hijos. Durante esos años la Garro entraba y salía del país y fue en 1968, después de la denuncia contra 500 intelectuales mexicanos, que se pierde ya todo contacto entre ella y Rojas Romero y esas luchas que su pluma ayudó a potenciar.

Garro, desde mi perspectiva es una genial creadora a la que aún se le debe en México un reconocimiento completo de su obra, una mujer border line, en esa línea fronteriza a la que muchas mujeres geniales son empujadas por una sociedad patriarcal en la que el reconocimiento se regatea a quienes no son dóciles consentidas del sistema, a las rebeldes que lo desafían y sin embargo buscan insertarse en el mismo con la autoridad de un varón y no pueden porque son mujeres, porque son independientes, porque cuestionan la doble moral hipócrita de la sociedad y las cabezas bien pensantes. 


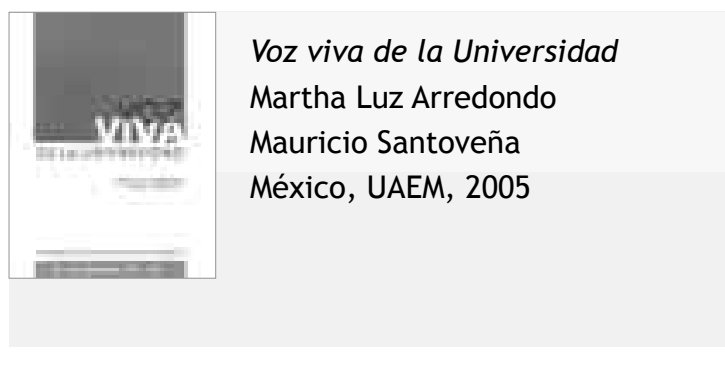

Con motivo del quincuagésimo aniversario de la fundación de nuestra UAEM, la administración que me honro en presidir instaló un comité organizador pa-ra celebrar tan memorable acontecimiento.

El libro que presentamos es la encarnación de uno de los objetivos prioritarios que formulara el comité organizador: poner a la disposición de cualquier miembro de la universidad, y a la del público en general, un texto actualizado que reconstruyese una porción importante de los procesos y vicisitudes que, significativamente, han marcado el derrotero de los primeros diez lustros de la UAEM.

Voz viva de la universidad es el fruto de tal iniciativa. Sin embargo, esta obra no nos remite, exclusivamente, a escudriñar en el pasado; su contenido está dirigido a vislumbrar, asimismo, nuestro posible futuro. En la confección de ambas miradas, los autores resuelven cederle la palabra a quienes en otro tiempo fueron rectores, directores de unidades académicas o administrativas, líderes sindicales y dirigentes estudiantiles.

El resultado es sorprendente y provechoso. Esperamos que el lector comparta nuestra modesta apreciación. R. Santoveña

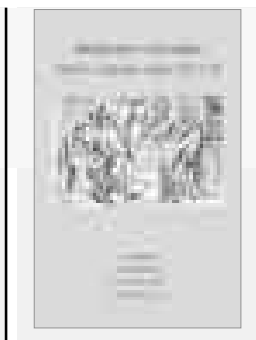

Imágenes cruzadas. México y España, siglos XIX y XX

A. Miquel, J. Nieto, T. Pérez (compiladores) México, UAEM, 2005

El libro Imágenes cruzadas. México y España, siglos $X I X$ y $X X$, es una novedad editorial de la UAEM. El presente volumen es una compilación que incluye diecinueve interesantes artículos, escritos por diferentes investigadores especializados en el área.

Los textos acopiados hacen referencia, como se menciona en su introducción, “a un tipo de imágenes que entran en ese amplio capítulo de la imagen del otro que tan importante lugar ocupa en todo imaginario colectivo. El otro que nos define y frente al que nos definimos, objeto tanto de nuestras fobias como de nuestras filias. En el caso de México y España la construcción del otro se convierte en un intrincado juego de espejos en el que la imagen reflejada es muchas veces la imagen de otro espejo, el otro que se empeña en ser uno y en el que nos empeñamos en vernos reflejado."

Los ensayos abordan diversos temas de la literatura, el periodismo, las artes populares, la caricatura, la fotografía, el cine y el diseño gráfico tanto de México como de España. Hechos que reflejan la riqueza en la composición de la historia de la cultura mexicana y la amplitud de enfoques en el oficio del investigador. 


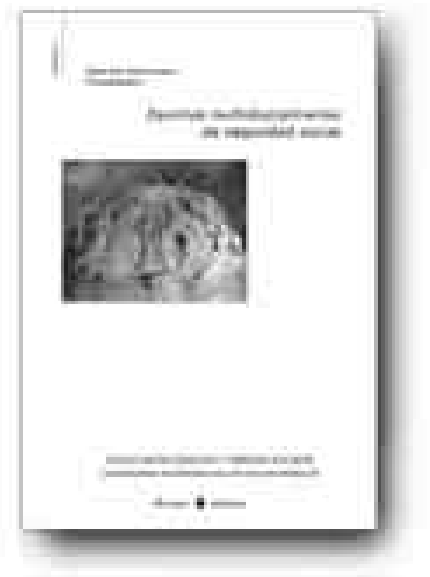

Ediciones Mínimas toma su nombre del concepto semiótico de mínimo como forma irreductible de un sema, de un signo, que es la unidad esencial de la estructura de un texto o de una imagen.

Se trata de una colección de calidad académica tanto en su presentación o soporte como en su contenido y expresión, resultado de la selección del quehacer intelectual que se desarrolla en la UAEM en la diversidad de sus ámbitos del conocimiento.

Comité Editorial - UAEM

\section{Colecciones}

Artes

Número 1

Acercamientos al cine silente mexicano Autor: Ángel Miquel

Número 2

Cerámica de Tlayacapan, estética e identidad Autora: Alma B. Sánchez

\section{Ciencias sociales}

Número 1

Apuntes multidisciplinarios de seguridad social Coordinadora: Gabriela Mendizábal

\section{Educación}

Número 1

Historia de la educación en el estado de Morelos. 1880-1940

Autora: Lucía Martínez Moctezuma

\section{Humanidades}

Número 1

Sentido y vigencia del pragmatismo Autor: José Miguel Esteban 
Despertar con ciencia y tecnología

\section{UFM Noticias}

El coleccionista

Salud y humanidades

Vía libre de la BBC

\section{Extensión}

\section{Radio Francia Internacional}

\section{Crónicas Universitarias}

Programa de investigación de formato documental que busca acercarse a la comunidad científica, académica y estudiantil, además del público en general.

Su atractivo está sustentado, tanto en la veracidad de sus contenidos por medio de tecnologías virtuales y animación, como en una cuidadosa dirección artística -imagen y música-, logrando un concepto visual digno de las investigaciones llevadas a cabo en la Universidad Autónoma del Estado de Morelos.

Se transmite los jueves, viernes y sábados por el Canal 3 del Sistema Morelense de Radio y Televisión.

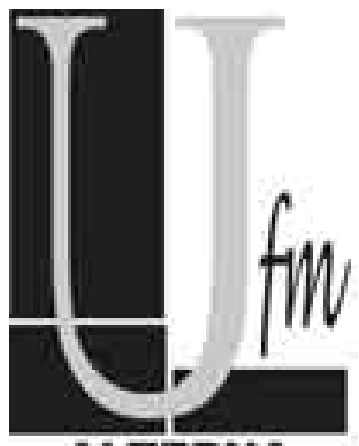

ALTERNA Radio UAEM 106.1 FM 